\title{
PERFORMANCE TEST REPORTS AND COMPARISON OF EMISSION CHARACTERISTICS OF PROTOTYPE LIQUID MULTIFUEL BURNERS DEVELOPED FOR U.S. MILITARY FIELD COOKING APPLICATIONS
}

W. Litzke, Y. Celebi, and R. Mc Donald

August 1994

Energy Efficiency \& Conservation Division

Department of Applied Science

Brookhaven National Laboratory

Upton, New York 11973

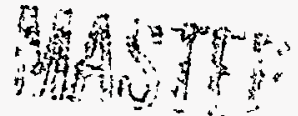

This work was performed under the auspices of the U.S. Department of Energy Washington, D.C. Under Contract No. DE-AC02-76CH00016 


\section{DISCLAIMER}

This report was prepared as an account of work sponsored by an agency of the United States Government. Neither the United States Government nor any agency thereof, nor any of their employees, nor any of their contractors, subcontractors, or their employees makes any warranty, express or implied, or assumes any legal liability or responsibility for the accuracy, completeness, or usefulness of any information, apparatus, product or process disclosed, or represents that its use would not infringe privately owned rights. Reference herein to any specific commercial product, process, or service by trade name, trademark, manufacturer, or otherwise, does not necessarily constitute or imply its endorsement, recommendation, or favoring by the United States Government or any agency thereof. The views and opinions of authors expressed herein do not necessarily state or reflect those of the United States Government or any agency, contractor, or subcontractor thereof. 


\section{DISCLAIMER}

Portions of this document may be illegible in electronic image products. Images are produced from the best available original document. 


\section{FOREWORD}

Under the agreements of the contract with the United States Army Natick Research and Development Center, Contract No. DAAK60-94-0019, Brookhaven National Laboratory provided four separate reports for the Testing of Prototype Advanced Burners Project. These include a Performance Test Report for each of the burners evaluated: the Army M-2 Gasoline Burner, the Army M-3 Multifuel Burner, the ITR Multifuel Burner, the Babington Multifuel Burner. These individual reports were compiled in their complete and original form and included within this report, which is a comparison of emissions characteristics of the prototype advanced burners, so that all information and results could be published as a single project report. 


\section{ACKNOWLEDGMENTS}

Robert Selvey and Ralph Wilson, S\&EP, for their very valuable consultations; Dave Elling, DAS, for his help in setting up the test facility, and Dr. Thomas Butcher, DAS, for his technical review of the test results. 


\section{TABLE OF CONTENTS}

1.1 Objective $\quad \ldots \ldots \ldots \ldots \ldots \ldots \ldots \ldots \ldots \ldots \ldots \ldots \ldots \ldots \ldots$

1.2 Background $\ldots \ldots \ldots \ldots \ldots \ldots \ldots \ldots \ldots \ldots \ldots \ldots$

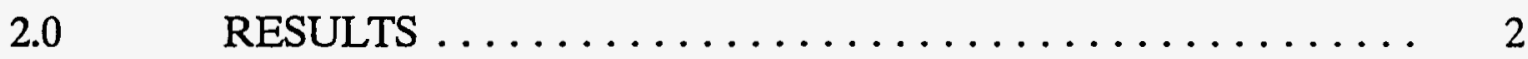

2.1 Particulate Emissions $\ldots \ldots \ldots \ldots \ldots \ldots \ldots \ldots \ldots$

2.2 Formaldehyde $\ldots \ldots \ldots \ldots \ldots \ldots \ldots \ldots \ldots \ldots \ldots \ldots$

2.3 Carbon Monoxide.$\ldots \ldots \ldots \ldots \ldots \ldots \ldots \ldots \ldots \ldots$

2.4 Nitrogen Oxides $\ldots \ldots \ldots \ldots \ldots \ldots \ldots \ldots \ldots \ldots \ldots \ldots \ldots$

2.5 Transient Smoke Levels during Startup . . . . . . . 7

3.0 COMPARISON WITH PUBLISHED DATA ON SIMILAR COMBUSTION SYSTEMS $\ldots \ldots \ldots \ldots \ldots \ldots \ldots \ldots \ldots, 7$

$4.0 \quad$ REFERENCES $\ldots \ldots \ldots \ldots \ldots \ldots \ldots \ldots \ldots \ldots \ldots \ldots \ldots \ldots \ldots$

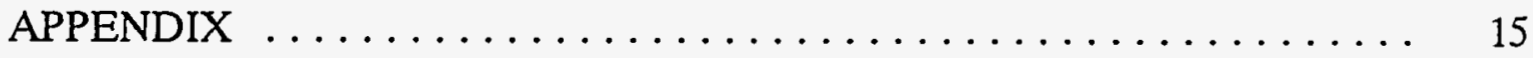




\section{LIST OF FIGURES}

FIGURES

PAGE

1

Particulate Emissions $\ldots \ldots \ldots \ldots \ldots \ldots \ldots \ldots \ldots$

As Measured Formaldehyde Concentrations $\ldots \ldots \ldots \ldots \ldots$. 5

3

Steady State Formaldehyde Concentrations Corrected

to $3 \% \mathrm{O}_{2} \ldots \ldots \ldots \ldots \ldots \ldots \ldots \ldots \ldots \ldots \ldots \ldots \ldots \ldots \ldots \ldots$

As Measured Carbon Monoxide Concentrations ........ 8

Steady State Carbon Monoxide Concentrations Corrected to $3 \% \mathrm{O}_{2} \ldots \ldots \ldots \ldots \ldots \ldots \ldots \ldots \ldots \ldots \ldots \ldots \ldots \ldots \ldots$

As Measured Nitrogen Oxides Concentrations $\ldots \ldots \ldots \ldots \ldots$

$7 \quad$ Steady State Nitrogen Oxides Concentrations

Corrected to $3 \% \mathrm{O}_{2} \ldots \ldots \ldots \ldots \ldots \ldots \ldots \ldots \ldots \ldots \ldots$

Transient Smoke Levels 


\section{LIST OF TABLES}

TABLES

PAGE

1 Published Emission Factors - lb/MBtu $\ldots \ldots \ldots \ldots \ldots \ldots \ldots$ 


\subsection{INTRODUCTION}

\subsection{Objective}

The objective of this project is to provide data to the U.S. Army Natick RD\&E Center on the performance of three prototype burners, which have the capability of firing with multiple types of fuels (diesel and JP-8), and the conventional gasoline-fired M-2 burner. The prototype burners are intended to replace the M-2 unit currently used in food cooking appliances in the Army. The burners supplied to Brookhaven National Laboratory (BNL) for the purpose of testing under this project included one M-2 unit, one M-3 prototype unit designed by Natick, one Babington prototype unit designed by Babington Engineering, and one ITR prototype designed by International Thermal Research Ltd. It should be noted, however, that after the project began, Babington Engineering provided an upgraded prototype unit for testing which replaced the unit initially provided by the Natick Center. The M-3 unit replaced the Karcher unit listed in the contract. These arrangements were agreed upon by the Army Project Officer and BNL at the outset of the experimental work.

The test procedures which were described in a Test Method Report allowed for the measurement of the concentrations of specific compounds emitted from the burners. These compounds included oxygen $\left(\mathrm{O}_{2}\right)$, carbon monoxide $(\mathrm{CO})$, oxides of nitrogen $(\mathrm{NOx})$, formaldehyde, and particulate emissions. The level of smoke produced was also measured by using a Bacharach Smoke Number system (ASTM Standard D2156).

A separate Performance Test Report for each burner was prepared as part of this project. In those reports details of the measurement techniques, instrumentation, test operating conditions, and data for each burner were included. This paper provides a summary and a comparison of the results for all burners. A brief discussion of emissions from other similar small oil combustion systems is also part of this document to provide perspective on the type of contaminants and levels expected from these systems.

\subsection{Background}

The U.S. Army is currently interested in the development of advanced cooking appliances which can be fueled with distillate oil (diesel and JP-8) and deployed in the field. These appliances will be used in semi-enclosed areas and so it is important that the combustion process be consistently clean. Pollutants of potential concern include carbon monoxide, aldehydes, and particulates.

Federal agencies such as the Occupational Safety and Health Administration (OSHA) establish standards for permissible exposure limits to ensure that employees are not exposed to airborne concentrations of specific contaminants that exceed these limits. The current accepted exposure limit over an 8-hour period for $\mathrm{CO}$ is 50 parts per million (ppm). The term "aldehydes" refers to a family of compounds with different levels of toxicity and concentration in combustion product exhaust. The dominant aldehyde in both exhaust products and the atmosphere is formaldehyde which has an 8-hour average exposure limit 
of $0.75 \mathrm{ppm}$. In automotive engine exhaust the total hydrocarbon emissions can be in the 100 's of ppm range and aldehydes may be about $1 / 3$ of the total. Nitrogen oxides (NOx) generated from fuel oil combustion consist mostly of nitric oxide (NO) which has an 8-hour average exposure limit of $25 \mathrm{ppm}$, and nitrogen dioxide $\left(\mathrm{NO}_{2}\right)$ which has a maximum limit of $5 \mathrm{ppm}$.

\subsection{RESULTS}

The M-2 and M-3 units are similar in design in that they both operate with a pressurized fuel delivery system; however, they differ in the types of fuel which can be used in these units. The M-2 provides a baseline of information by which all new prototypes can be compared. On the other hand, all of the prototype units tested have the same capabilities as the M-3 for petroleum distillate use.

Safety considerations necessitated that the M-2 and $\mathrm{M}-3$ units be ignited outdoors and heated up in a lengthy warmup period before returning the units to the laboratory for measurements. As a result emissions emitted during the transient period could not be measured.

Most of the results are presented in graphs which provide the basis for all discussions; the Appendix contain tables which include numerical values for each set of tests as well as conversion of values to equivalent units which are helpful when comparing these results with existing published data. For all graphs each set of results are grouped according to burner and fuel type. A comparison of all burners are made based on the firing rate: HIGH 46,00063,000 Btu/hr, MEDIUM 29,000-45,400 Btu/hr, and LOW 18,700-28,200 Btu/hr ; all burners were tested over a broad range.

The data are given "as measured," the direct readings of stack concentrations under actual conditions of excess air (determined by the measured oxygen content of the flue gas). Although it is very likely that concentrations of contaminants emitted during operation of the cookstoves under actual field conditions will differ from experimental values, it is reasonable to say that the "as measured" values are estimates of the maximum concentrations which could be found in the actual case. For comparison of emissions on the same basis with equivalent excess air, values are also presented as "corrected to $3 \% \mathrm{O}_{2}$, which account for differences in dilution in the sample collection hood. These calculated values are not only useful for comparing emissions between burners for this study but also for comparing with existing published data for other combustion sources. The tables in the Appendix provide the numerical values for the data presented in the graphs.

The Babington burner (BAB) and the ITR unit were the only two burners that were operated in both cyclic and steady state mode. During the cyclic tests the maximum firing rate for that particular burner was used for both diesel and JP-8 fuel. The units were turned on and off in successive cycles to generate substantial amounts of contaminants emitted that were collected for analysis. For the M-2 and M-3 tests were conducted with three and two 
firing rates, respectively; cyclic (or transient) measurements were not made for these units because of the long outdoor startup period required to warm-up these burners.

Each test consisted of one set of measurements at that particular test condition and firing rate. As such, each numerical value cannot be defined as absolute and can only be used to make observations on trends and comparisons of one burner to another, or performance of a fuel type with the same burner. The discussions that follow will focus on gross differences that were deemed significant.

\subsection{Particulate Emissions}

Figure 1 summarizes the results of all particulate emissions. For the two burners in which cyclic tests were done, particulate emissions were higher during the cyclic mode when compared to the steady mode. The exception was with the ITR burner using JP-8 in which at the low firing rate steady state emissions were higher than the cyclic emissions. The maximum amount was generated with the ITR unit using diesel at $0.14 \mathrm{lb} / 100 \mathrm{lb}$ of fuel. In general, it is expected that the highest emissions are generated with these units during transient periods (startup and shutdown). At steady state all burners emitted almost the same amount, with the M-3 unit slightly higher than the rest on average.

It is hard to draw any firm conclusions about the relative amounts of particulates emitted with respect to firing rate or fuel type. Although, data from the ITR and M-2 tend to indicate that more particulates are generated at lower firing rates.

\subsection{Formaldehyde}

Figure 2 shows the formaldehyde emissions as measured in the stack averaged over the sampling period for both cyclic and steady state operation. The highest levels observed occurred during cyclic operation of the ITR unit ranging from 7-9 ppm for both diesel and JP-8 fuel. When steady state operation is considered only, the highest levels were measured from the M-2 unit at $1 \mathrm{ppm}$. For comparison it is more useful to look at

Figure 3 to determine that the M-2 units emissions exceed the other burners on average by at least three times and seem to increase with decreasing firing rate. The $\mathrm{BAB}$ burner emitted the lowest levels.

\subsection{Carbon Monoxide}

Some transient measurements were made for all burners for the brief period during startup and/or shutdown; these are indicated by start peak or stop peak, respectively. For the BAB and ITR burners peaks during both startup and shutdown were measured. As indicated earlier, the M-2 and M-3 startup emissions could not be measured because 


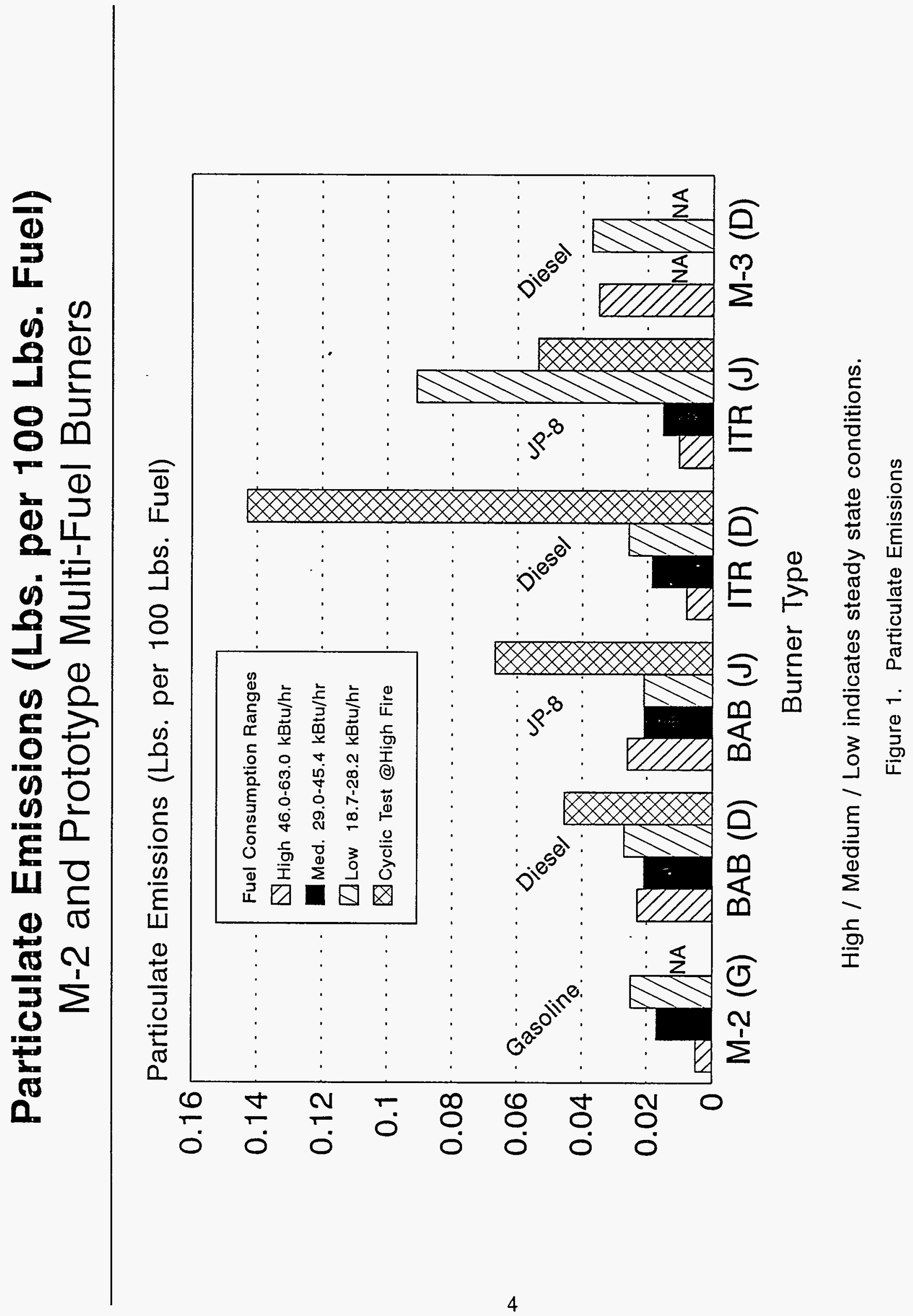




\section{Formaldehyde Emissions (As Measured)}

M-2 and Prototype Multi-Fuel Burners

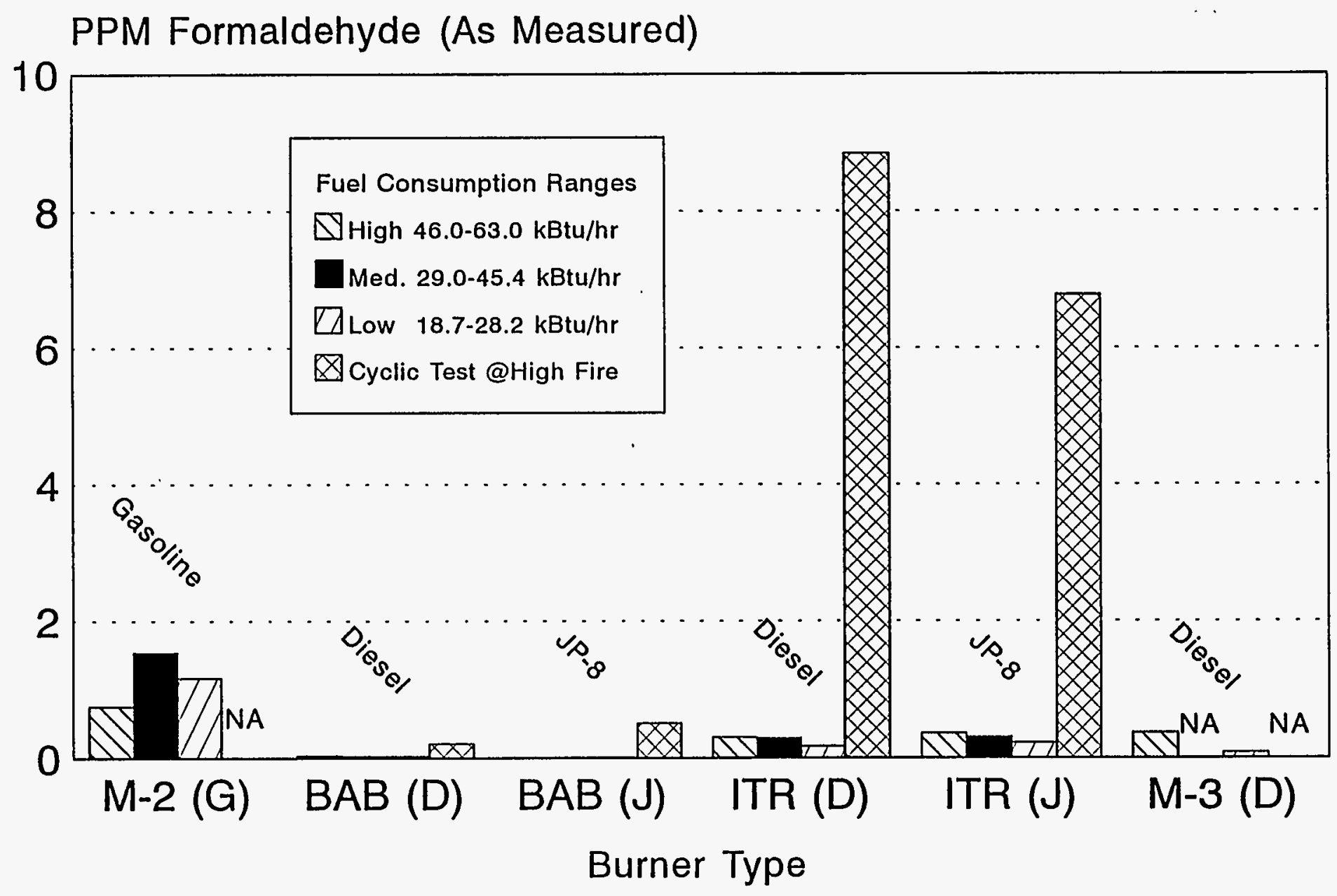

Note: Excess air levels are not constant for data presented.

Figure 2. As Measured Formaldehyde Concentrations 


\section{Steady State Formaldehyde Emissions M-2 and Prototype Multi-Fuel Burners}

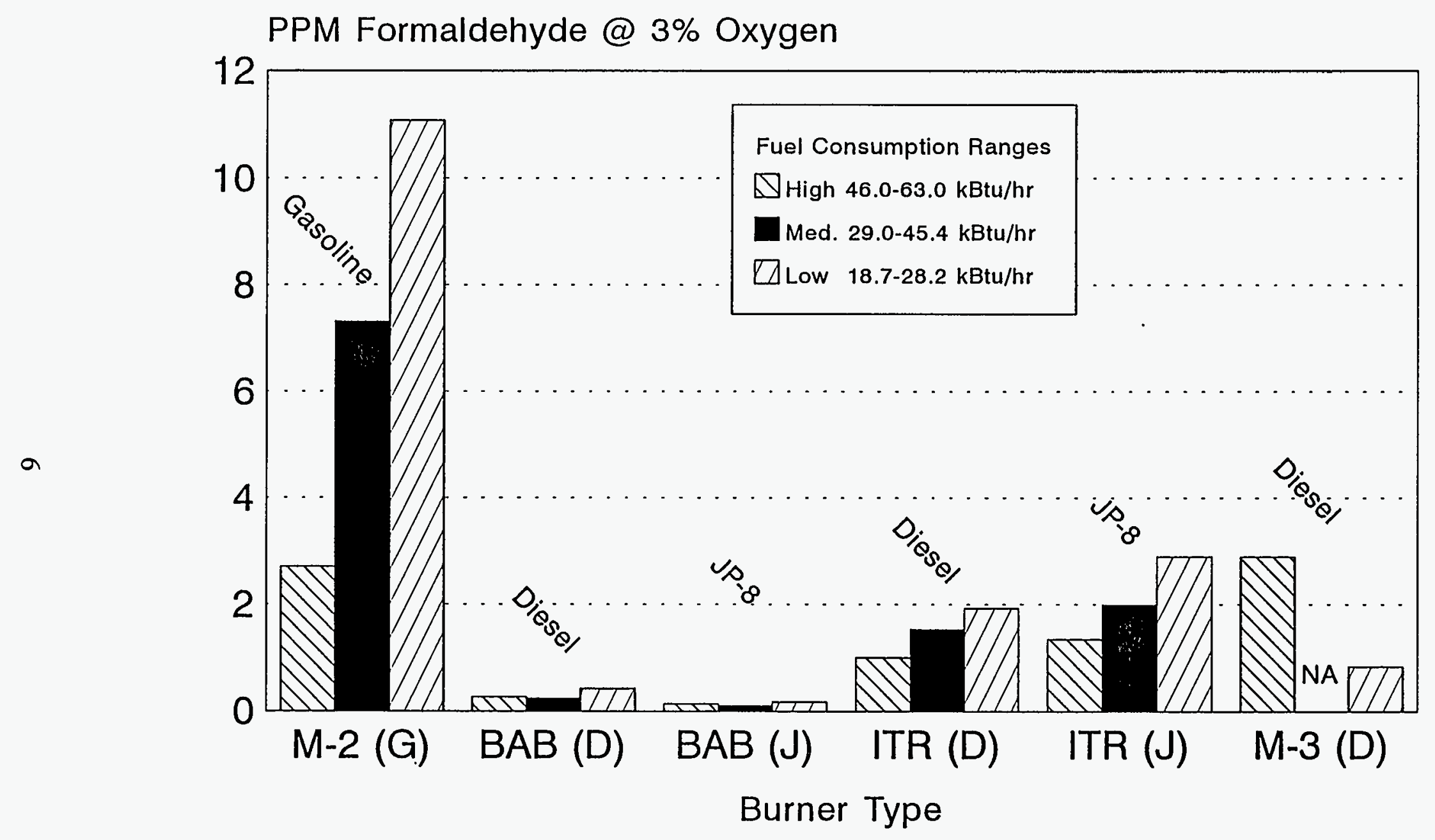

Data corrected to $3 \%$ Oxygen concentration for comparison.

Figure 3. Steady State Formaldehyde Concentrations corrected to $3 \% \mathrm{O} 2$ 
these units were ignited and warmed up outdoors and not within the experimental facility required for the measurements.

Refer to Figure 4 for the "as measured" results. From the data taken with BAB and ITR, it is clear that the greatest amount of carbon monoxide is generated during startup. The amount emitted by the ITR unit was more than $5000 \mathrm{ppm}$, which was the maximum limit in the range of the analytical instrument. Although the $\mathrm{BAB}$ unit shows elevated $\mathrm{CO}$ levels during startup, ranging from 95 to $110 \mathrm{ppm}$, they are much lower than that found with the ITR unit. Shutdown emissions are roughly the same for all burners with an average of $5 \mathrm{ppm}$. Figure 5 shows that during steady state mode all burners operated similarly within a small range of emissions.

\subsection{Nitrogen Oxides}

Measurement of nitrogen oxides concentration is performed during steady state operation and the values given in Figure 6 are the averages during the "on" period of the firing cycle. On an "as measured" basis no significant differences can be discerned of the actual stack concentrations for the BAB, ITR, or the M-3 units. The M-2 burner shows about half the emissions of the other burners. This lower trend is much more evident from looking at Figure 7. In this graph $\mathrm{BAB}$ and $\mathrm{M}-3$ burners indicate at least twice the emissions of the ITR unit and five times the emissions from the M-2 gasoline unit.

\subsection{Transient Smoke Levels during Startup}

For the $\mathrm{BAB}$ and ITR burners smoke density during startup was measured and the results are shown in Figure 8. These graphs give information on the relationship of the smoke number, measured on a Bacharach scale, with respect to time. A comparison is made between burner type, fuel type (diesel and JP-8) and firing rate. Results show that the transient smoke levels generated by the ITR unit are always higher than for the BAB unit. A maximum smoke number of No. 6 was measured with the ITR burner, and a No. 1 for the $\mathrm{BAB}$ burner. In both cases, more smoke was observed when firing with diesel than with JP-8, independent of the firing rate. In steady state both units operated with a zero smoke firing either diesel or UP-8.

\subsection{COMPARISON WITH PUBLISHED DATA ON SIMILAR COMBUSTION SYSTEMS}

The mechanical means by which the cookstoves operate and the firing ranges are very similar by design to other stationary combustion systems such as residential oil heating equipment. In fact, the $\mathrm{BAB}$ burner was derived from a slightly larger version of an air

atomized residential heating oil burner marketed in Europe. Several sources of published emission factors exist for residential heating systems which can be used to compare and evaluated the performance of the stoves tested in this project. 


\section{Carbon Monoxide Emissions (As Measured) M-2 and Prototype Multi-Fuel Burners}

PPM Carbon Monoxide (As Measured)

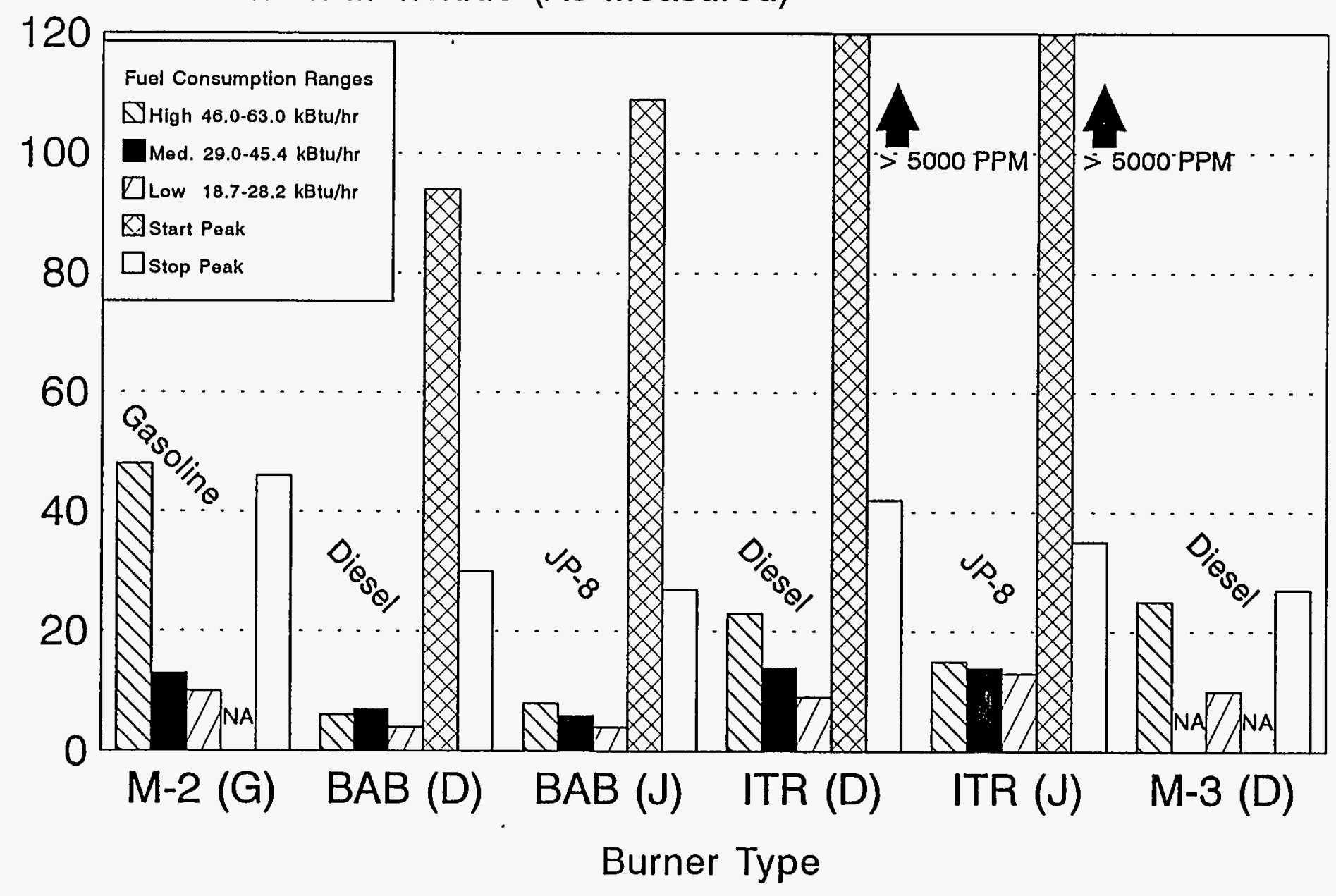

Note: Excess air levels are not constant for data presented.

Figure 4. As Measured Carbon Monoxide Concentrations 


\section{Steady State Carbon Monoxide Emissions M-2 and Prototype Multi-Fuel Burners}

PPM Carbon Monoxide @ 3\% Oxygen

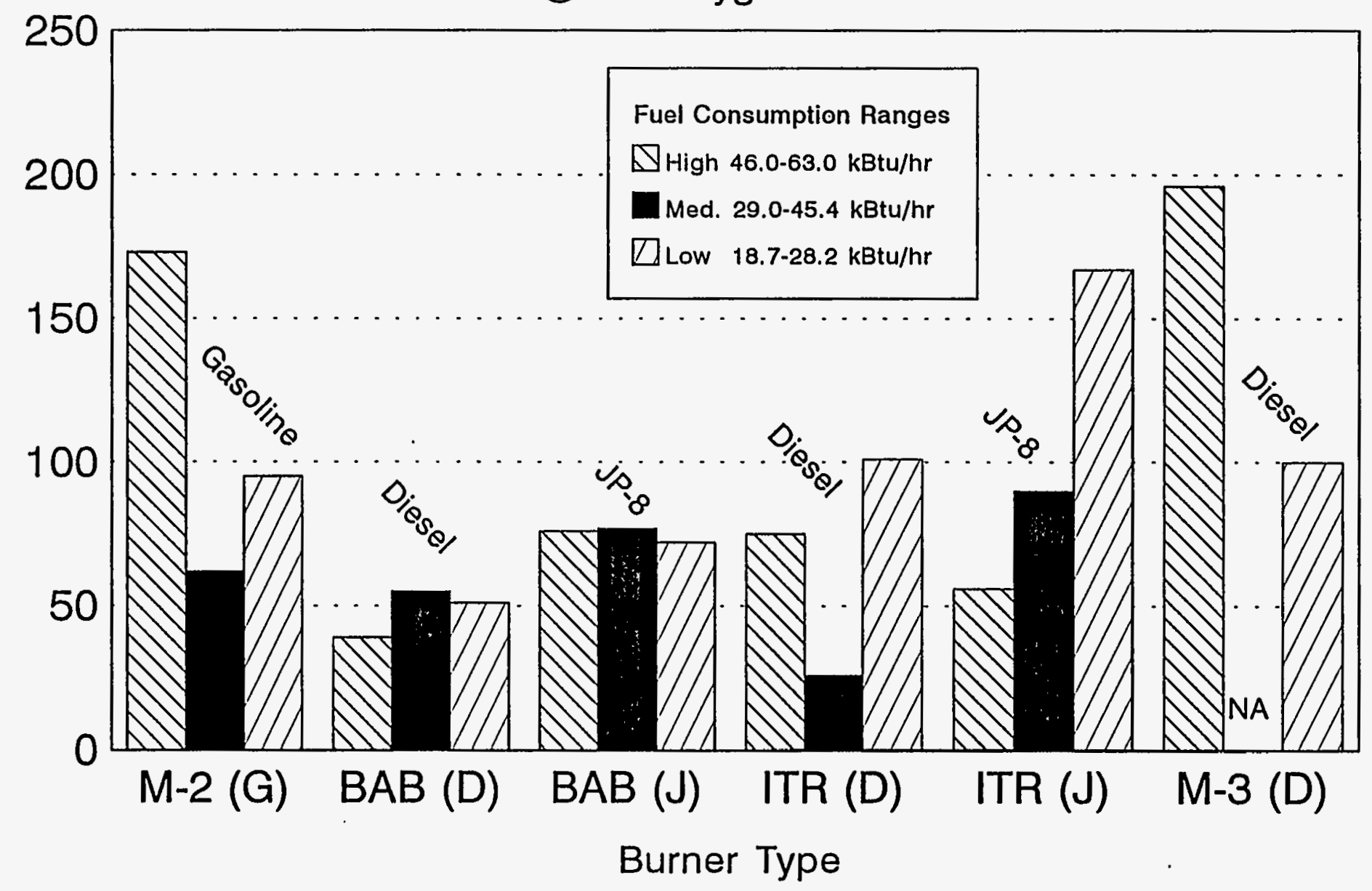

Data corrected to $3 \%$ Oxygen concentration for comparison.

Figure 5. Steady State Carbon Monoxide Concentrations corrected to $3 \% \mathrm{O} 2$ 


\section{Nitrogen Oxides Emissions (As Measured) M-2 and Prototype Multi-Fuel Burners}

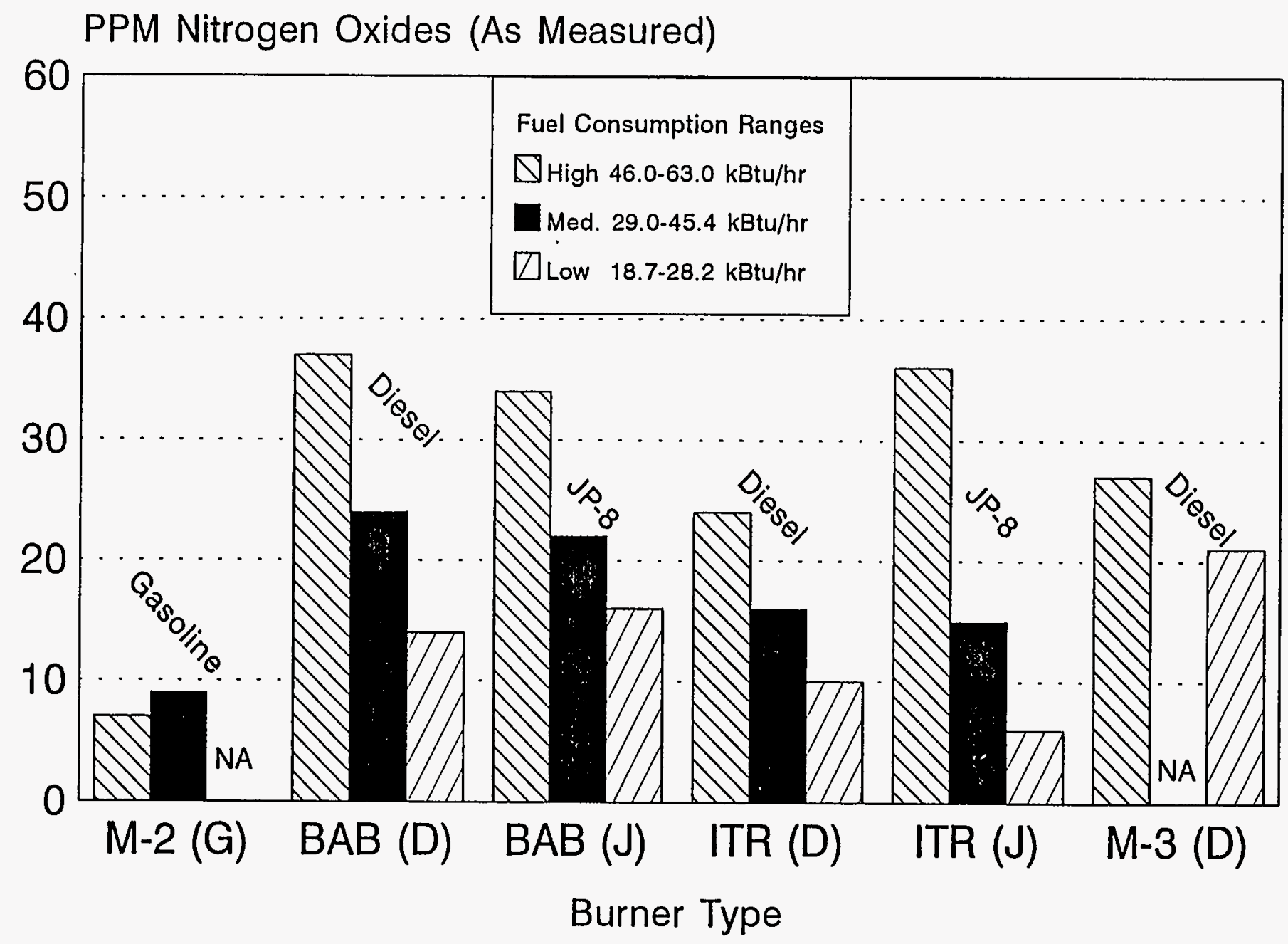

Note: Excess air levels are not constant for data presented.

Figure 6. As Measured Nitrogen Oxides Concentrations 


\section{Steady State Nitrogen Oxides Emissions M-2 and Prototype Multi-Fuel Burners}

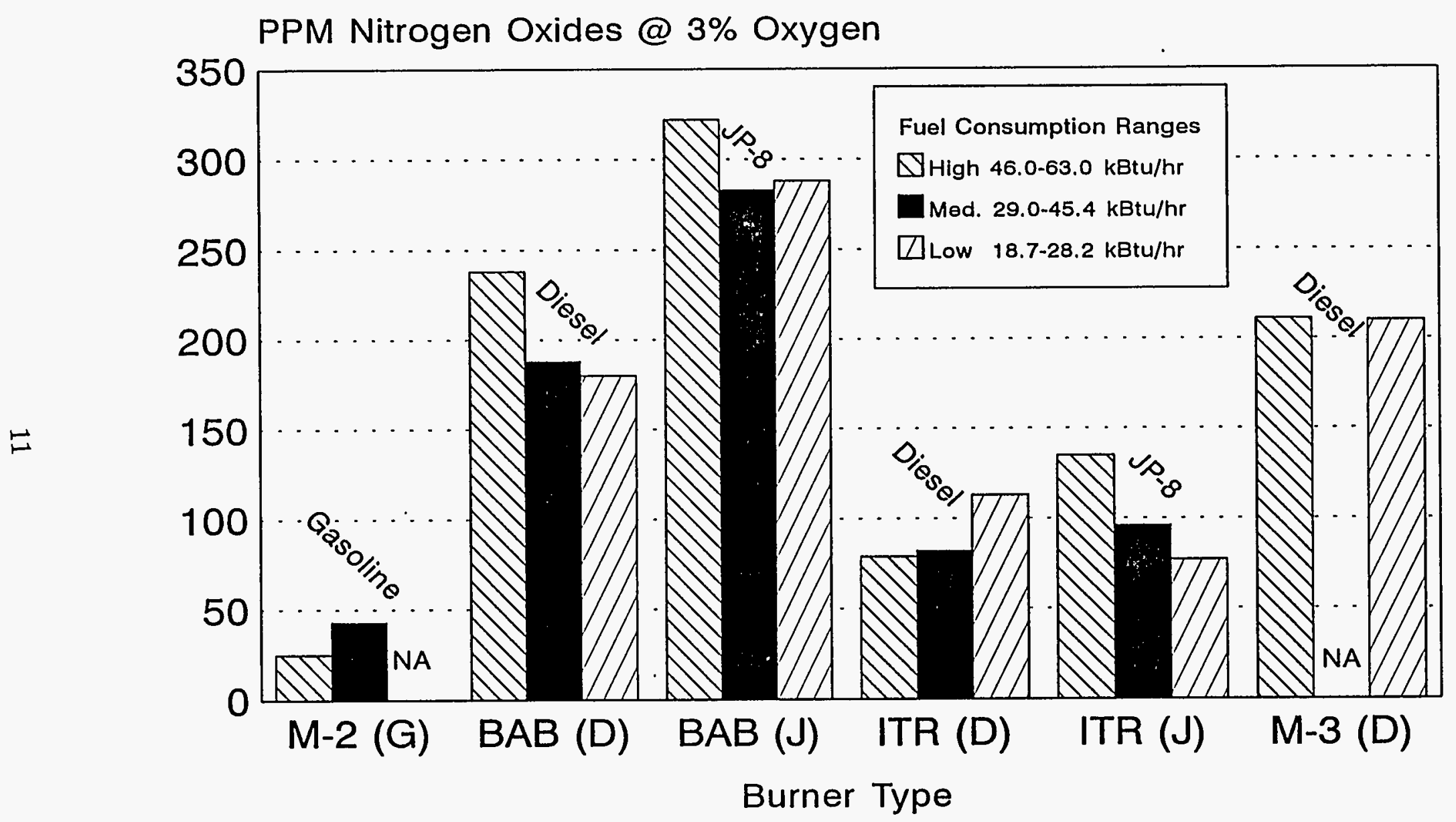

Data corrected to $3 \%$ Oxygen concentration for comparison.

Figure 7. Steady State Nitrogen Oxides Concentrations corrected to $3 \% \mathrm{O} 2$ 


\section{Babington Prototype Stove Transient Smoke Level during Startup}

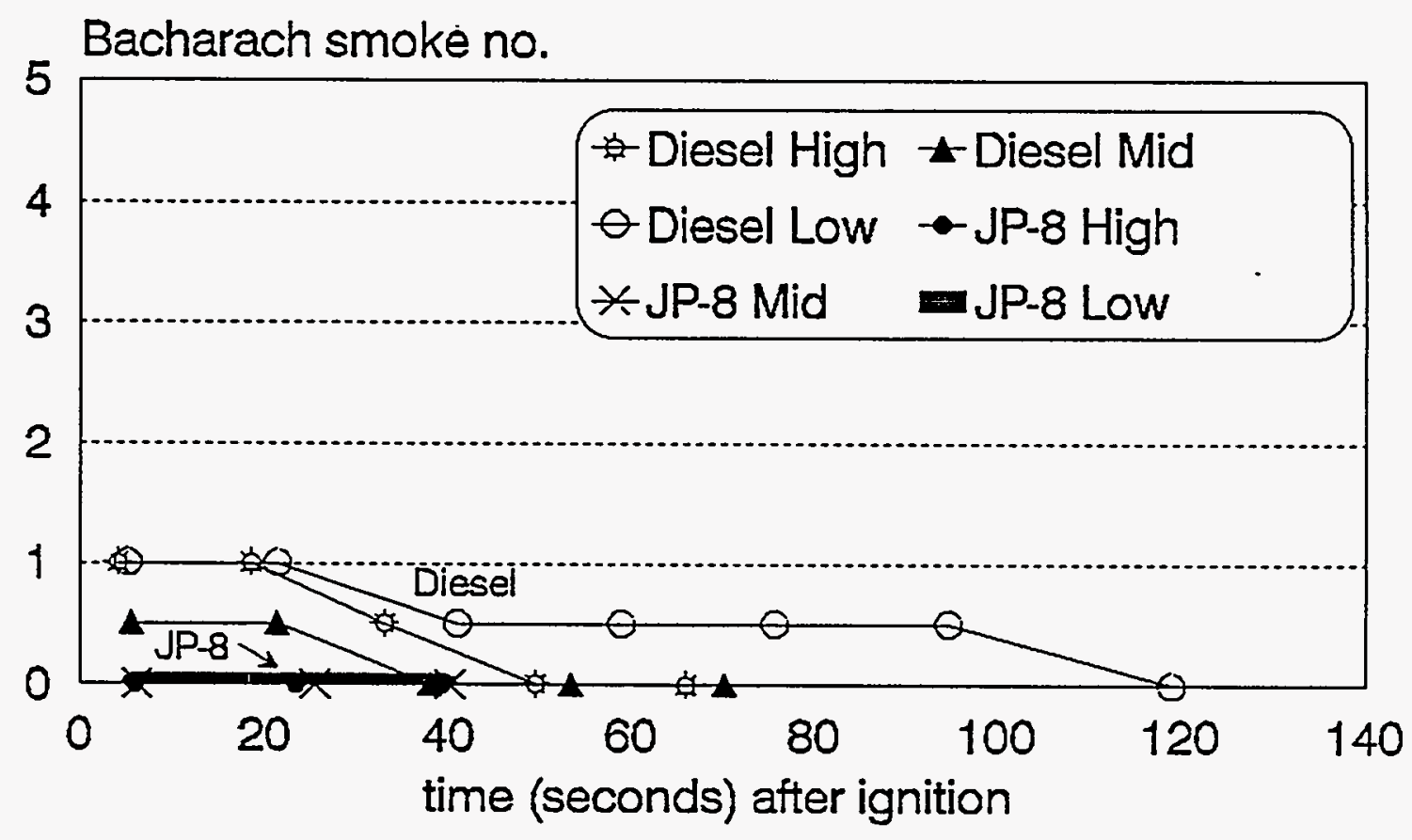

ITR Prototype Stove Transient Smoke Level during Startup

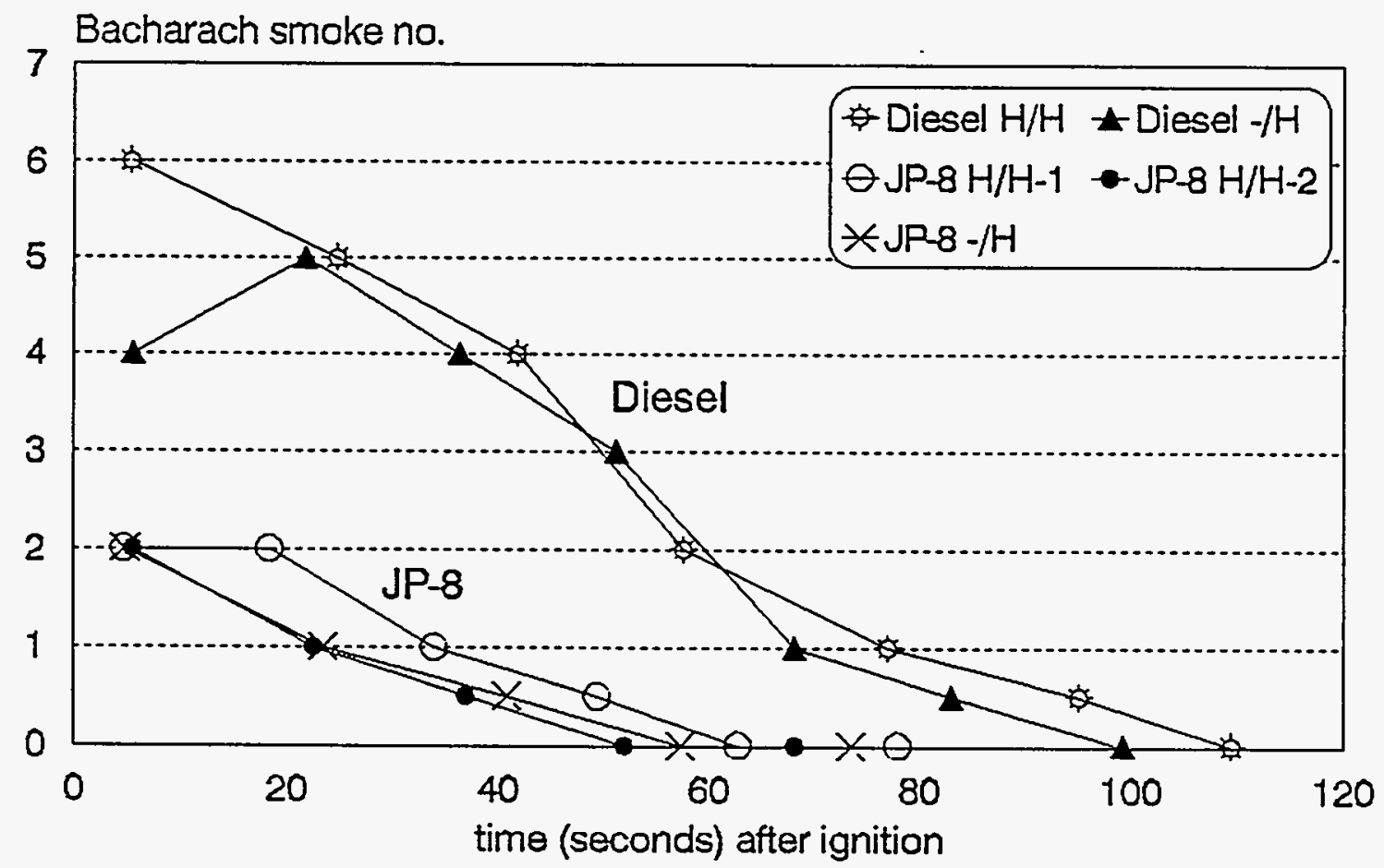

Figure 8. Transient Smoke 
An emission factor is an average value which relates the quantity of a pollutant released to the atmosphere with the activity associated with the release of that pollutant. In combustion systems, it is usually expressed as the weight of pollutant divided by a unit weight, volume, or energy consumed. The Environmental Protection Agency (EPA) publishes such factors to permit estimation of emissions from various sources. In most cases, these factors are simply averages of all available data from typical existing sources [1]. Table 1 shows emission factors for some of the typical pollutants found in distillate oil-fired systems. McCrillis and Watts in a later study done for the EPA provided additional data from their field work that indicated that for a typically tuned, new, flame retention head burner even lower particulate emissions could be obtained [2]. Data from a recent and more extensive study on the emissions characteristics of modern oil heating equipment done by Krajewski et.al. found that for a well-tuned modern flame retention head burner emission factors are very small [3]. Also included in this table are data obtained for the advanced prototype burners from this project for comparison; presented are the average values measured during steady state conditions for those burners that were fired with diesel fuel. The results for the prototype burners are quite comparable with the EPA emission factors and data from modern heating equipment. Based on the relative contribution of residential oil heating equipment to the national inventory of emissions, EPA does not consider it a major concern.

\begin{tabular}{|c|c|c|c|}
\hline & $\begin{array}{c}\text { Particulate } \\
\text { Matter }\end{array}$ & CO & NOx \\
\hline EPA & 0.018 & 0.036 & 0.13 \\
\hline McCrillis \& Watts & 0.0035 & --- & -- \\
\hline Krawjeski & 0.0027 & 0.026 & 0.15 \\
\hline $\begin{array}{c}\text { Prototype Burners } \\
\text { (Diesel) }\end{array}$ & 0.012 & 0.063 & 0.21 \\
\hline
\end{tabular}

Table 1. Published Emission Factors - lb/ MBtu 


\subsection{REFERENCES}

[1] Compilation of Air Pollutant Emission Factors, Volume I: Stationary Point and the Area Sources, Fourth Edition, U.S. Environmental Protection Agency, Sept 1985, PB86-124906.

[2] McCrillis, R. C., and Watts, R. R., Analysis of Emissions from Residential Oil Furnaces, U.S. Environmental Protection Agency, 1992, Report No. 92-110.06.

[3] R. Krajewski, Y. Celebi, R. Coughlan, T. Butcher, and R.J. McDonald, Emissions Characteristics of Modern Oil Heating Equipment, Brookhaven National Laboratory, Project Report No. BNL-52249. 


\begin{abstract}
APPENDIX
Included in this section are data tables with numerical values that were used to generate the graphs shown in the main body of the report.
\end{abstract}




\begin{tabular}{|c|c|c|c|c|c|c|c|c|}
\hline$\varsigma 9 \varepsilon$ & $5+5$ & sts & $\$ 69$ & $0 £ 9$ & $\angle \varepsilon \varepsilon$ & $\varsigma 9 \varsigma$ & $91 \mathrm{~L}$ & 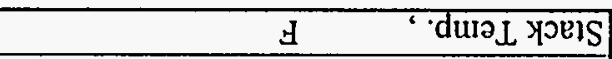 \\
\hline$S \angle+0^{\circ} 0$ & $\varepsilon 90^{\circ} 0$ & SLSO 0 & $\$ 90^{\circ} 0$ & $290^{\circ} 0$ & $S 0^{\circ} 0$ & $90^{\circ} 0$ & $\$ 90^{\circ} 0$ & 'yеsp yoels \\
\hline \multirow[t]{2}{*}{ S6ZI } & $\varepsilon 8 \varepsilon$ & E09 & EIE & olt & 0 EIII & $\angle 9 t$ & +92 & $1 ! \forall$ SSอว $\exists \%$ \\
\hline & & & & & & & & :suo!n!puoj gu!̣esado \\
\hline \multirow[t]{2}{*}{$610^{\circ} 0$} & $600^{\circ} 0$ & SI00 & $0 \mathrm{IO}^{\circ} 0$ & $\angle 10^{\circ} 0$ & 9200 & $610^{\circ} 0$ & $800^{\circ} 0$ & 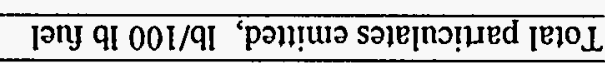 \\
\hline & & & & & & & & \\
\hline $06^{\circ} \mathrm{Z}$ & 06.0 & $00 \tau$ & $\Phi \varepsilon^{\prime} I$ & 86.0 & $E 6 . \mathrm{I}$ & $E S^{\prime} I$ & $00 \%$ & 'әркиәрјетиов \\
\hline$L L$ & 0 I I & 96 & $\underline{S E I}$ & $\subseteq Z I$ & $\varepsilon I I$ & 28 & $6 L$ & $\mathrm{xON}$ \\
\hline$\angle 9 I$ & I0I & 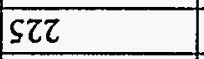 & 95 & +61 & $I L E$ & ZL & t2I & 'yead ullopinys - OJ \\
\hline$\angle 91$ & 99 & 06 & $9 S$ & 69 & $10 I$ & 92 & $S L$ & 'วleIs КpeวIS - OJ \\
\hline \multirow[t]{3}{*}{$000 \varsigma<$} & $000 \varsigma<$ & $000 \varsigma<$ & $000 S<$ & $000 \varsigma<$ & $000 \varsigma<$ & $000 \varsigma<$ & $000 S<$ & udd $\quad$ 'dnuels - OD \\
\hline & & & & & & & & 20\%ع 07 polpo.s.10J suo! \\
\hline & & & & & & & & \\
\hline$\varepsilon Z^{\circ} 0$ & $12^{\circ} 0$ & IEO & $9 \varepsilon^{\circ} 0$ & $12^{\circ} 0$ & $\angle I^{\circ} 0$ & $0 \varepsilon^{\prime} 0$ & $I \varepsilon^{\prime} 0$ & 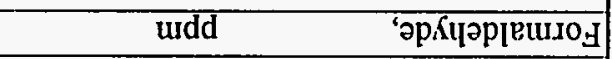 \\
\hline 9 & $\underline{s q}$ & SI & $9 \varepsilon$ & $\angle Z$ & OI & 91 & $t z$ & $\mathrm{x}_{\mathrm{ON}}$ \\
\hline$\varepsilon \mathrm{E}$ & $\varepsilon Z$ & SE & SI & $2 t$ & $\varepsilon \varepsilon$ & tI & $8 \varepsilon$ & 'yeəd unoplnys - OD \\
\hline$\varepsilon \mathrm{E}$ & SI & $b I$ & $S I$ & SI & 6 & $S$ & $\varepsilon z$ & 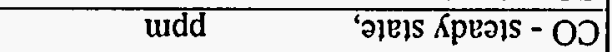 \\
\hline $006 \varepsilon$ & $000 \mathrm{~S}<$ & $000 \varsigma<$ & $000 \varsigma<$ & $000 \mathrm{~S}<$ & $000 \varsigma<$ & $000 \varsigma<$ & $000 \varsigma<<$ & 'yead dnjueis - OJ \\
\hline \multirow[t]{3}{*}{$96 \mathrm{I}$} & $69 I$ & $2.8 I$ & $z \cdot 91$ & \begin{tabular}{|l|l}
$\mathrm{I} L \mathrm{LI}$ \\
\end{tabular} & $76 I$ & $S: L I$ & S'SI & $20 \%$ \\
\hline & & & & & & & & 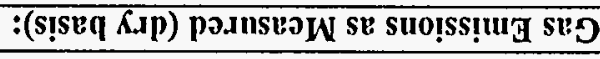 \\
\hline & & & & & & & & \\
\hline$\varepsilon z$ & L'ES & st & E'Z9 & $9^{\circ}+s$ & $s 2 z$ & $\varepsilon+t$ & 9.85 & xy/n!gy 'วlex \&u!u!H \\
\hline $8-\mathrm{d} C$ & $8-\mathrm{dC}$ & $8-\mathrm{dI}$ & $8-\mathrm{dr}$ & Iəsə!a & [əSə!] & [əsə! & |วSว!a & $\partial \mathrm{dd} \kappa_{\mathrm{L}}\left[\mathrm{n}_{\mathrm{H}}\right.$ \\
\hline MOT/ - & प8ิ!H/MOT & MoT/MOT & 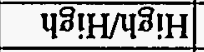 & $48 ิ ! \mathrm{H} / \mathrm{MO}$ & $\mathrm{MO} \mathrm{Z}^{-}$ & $1107 / 1107$ & 4ภ! & 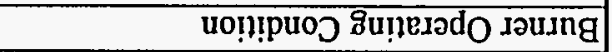 \\
\hline QLII & ULII & X.LI & \&LII & Y.III & Y.LI & Y.LI & Q.LI & ad $\kappa_{\perp}$ dəuing \\
\hline
\end{tabular}




\begin{tabular}{|c|c|c|c|c|c|c|c|c|c|c|c|}
\hline Burner Type & $\mathrm{M3}$ & $\mathrm{M} 3$ & M2 & $\mathrm{M} 2$ & M2 & Babington & Babington & Babington & Babington 1 & Babington & Babington \\
\hline Burner Operating Condition & High & Low & High & Mid & Low & \begin{tabular}{|l|} 
High \\
\end{tabular} & Mid & Low & \begin{tabular}{|l|l} 
High & 1 \\
\end{tabular} & Mid & Low \\
\hline Fuel Type & Diesel & Diesel & Gasoline & Gasoline & Gasoline & Diesel & Diesel & Diesel & $\mathrm{JP}-8$ & JP-8 & $\mathrm{JP}-8$ \\
\hline Firing rate, $\mathrm{kBtu} / \mathrm{hr}$ & 59 & 28.2 & 63 & 40.1 & 22.6 & 57.5 & 45.4 & 20.6 & 46 & 29 & 18.7 \\
\hline Gas Emiscions as Measured (drv basis): & & & & & & & & & & & \\
\hline$\% \mathrm{O} 2$ & 18.7 & 19.2 & 16 & 17.2 & 19.1 & 0 & 0 & $\mathbf{0}$ & 0 & 0 & $\overline{0}$ \\
\hline CO - startup peak, & NA & NA & NA & $\mathrm{NA}$ & $\mathrm{NA}$ & 25 & 18 & $\overline{94}$ & 21 & 109 & $\overline{43}$ \\
\hline CO - steady state, & 25 & 10 & 48 & 13 & 10 & 6 & 7 & 4 & 8 & 6 & 4 \\
\hline CO - shutdown peak, & 25 & 10 & 46 & 13 & 10 & 30 & 16 & 4 & 27 & 18 & 9 \\
\hline NOx & 27 & 21 & 7 & 9 & & 37 & 24 & 14 & 34 & 22 & 16 \\
\hline Concentration of formald. in stack, $\mathrm{pp}$ & 0.37 & 0.08 & 0.75 & 1.54 & 1.17 & 0.04 & 0.03 & 0.03 & 0.01 & 0.01 & 0.01 \\
\hline & & & & & & & & & & & \\
\hline Emissions corrected to 3\% 02 & & & & & & & & & & & \\
\hline CO - startup, $\quad \mathrm{ppm}$ & $\mathrm{NA}$ & NA & NA & NA & NA & 161 & 141 & 1209 & 199 & 1401 & 774 \\
\hline CO - steady state, $\quad$ ppm & 196 & 100 & 173 & 62 & 95 & 39 & 55 & 51 & 76 & 77 & 72 \\
\hline CO - shutdown peak, $\quad$ ppm & 196 & 100 & 166 & 62 & 95 & 193 & 125 & 51 & 256 & 231 & 162 \\
\hline NOx & 211 & 210 & 25 & 43 & 0 & 238 & 188 & 180 & 322 & 283 & 288 \\
\hline Formaldehyde, & 2.90 & 0.87 & 2.71 & 7.31 & 11.08 & 0.27 & 0.25 & 0.43 & 0.14 & 0.11 & 0.18 \\
\hline Total particulates emitted, $\mathrm{lb} / 100 \mathrm{lb}$ fuel & 0.035 & 0.037 & 0.005 & 0.017 & 0.025 & 0.023 & 0.021 & 0.027 & 0.026 & 0.021 & 0.021 \\
\hline & & & & & & & & & & & \\
\hline Operating Conditions: & & & & & & & & & & & \\
\hline$\%$ Excess Air & 759 & 995 & 297 & 420 & 930 & 607 & 759 & 1304 & 931 & 1295 & 1845 \\
\hline Stack draft, & 0.055 & & 0.065 & & 0.05 & 0.06 & 0.055 & 0.05 & 0.058 & 0.052 & 0.045 \\
\hline Stack Temp. & 512 & 392 & 717 & 547 & 410 & 528 & 424 & 353 & 521 & 424 & 337 \\
\hline
\end{tabular}




\begin{tabular}{|c|c|c|c|c|c|c|c|c|}
\hline 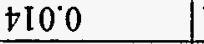 & 1100 & $2 \mathrm{~L} 0^{\circ} 0$ & $Z[00$ & $800^{\circ} 0$ & $\varepsilon 00^{\circ} 0$ & $610^{\circ} 0$ & $810^{\circ} 0$ & 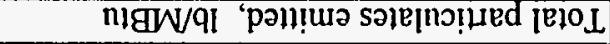 \\
\hline $5000^{\circ} 0$ & $2000^{\circ} 0$ & $2000^{\circ} 0$ & $1600^{\circ} 0$ & $0900^{\circ} 0$ & $2200^{\circ} 0$ & $\angle 000^{\circ} 0$ & $\$ 2000$ & 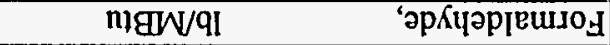 \\
\hline $\subseteq E Z^{\circ} 0$ & $9+\tau^{\circ} 0$ & IIE0 & $\forall \mathrm{N}$ & $t S 0^{\circ} 0$ & $Z \varepsilon 0^{\circ} 0$ & $+\angle 20$ & $9 \angle \tau^{\circ} 0$ & mgW/qI \\
\hline $1+0^{\circ} 0$ & $00 I^{\prime} 0$ & $t S I^{\circ} 0$ & $Z \angle 0^{\circ} 0$ & $\angle+00^{\circ}$ & $\angle Z I^{\prime} 0$ & $6 \angle 0^{\circ} 0$ & $9 S^{\circ} 0$ & 'Yead usiopinus - OJ \\
\hline $1+0.0$ & $5 t 0^{\circ} 0$ & IEO०0 & $Z \angle 0^{\circ} 0$ & $\angle+0^{\circ} 0$ & $\varepsilon$ & $6 \angle 0^{\circ} 0$ & $9 \mathrm{SI}^{\circ} 0$ & 'כІеIS KpeวIS - OJ \\
\hline \multirow[t]{3}{*}{0} & 0 & 0 & $16 \mathrm{I}$ & $\tau / \mathrm{LI}$ & $9 \mathrm{I}$ & $26 \mathrm{I}$ & $\angle 8 I$ & $20 \%$ \\
\hline & & & & & & & & 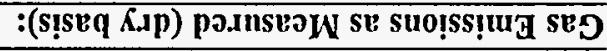 \\
\hline & & & & & & & & \\
\hline 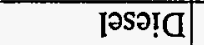 & Iอsว!ם & 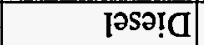 & อu!̣oseg| & อU!̣OSED & วน!̣OSED & paso!a & pəsə!a & \multirow{2}{*}{ 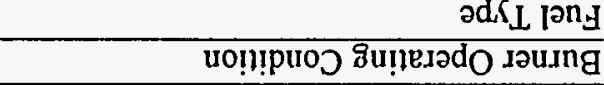 } \\
\hline 107 & $\mathrm{p} ! \mathrm{W}$ & पवิ!ก & $110 \mathrm{~T}$ & $\mathrm{p} ! \mathrm{W}$ & $48 \div \mathrm{H}$ & 1107 & $\mathrm{4} \delta$ & \\
\hline uolsu!̣eg & uoldutqeg & uolsిu!qeg & ZW & ZW & ZW & EW & $\varepsilon W$ & adא $K_{\mathrm{L}}$ Jouing \\
\hline $010^{\circ} 0$ & $700^{\circ} 0$ & $800^{\circ} 0$ & $500^{\circ} 0$ & $600^{\circ} 0$ & $\$ 10^{\circ} 0$ & $010^{\circ} 0$ & 5000 & 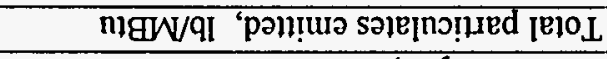 \\
\hline $7200^{\circ} 0$ & $\angle 000^{\circ} 0$ & $\angle I 00^{\circ} 0$ & II $00^{\prime} 0$ & $8000^{\prime} 0$ & $9100^{\circ} 0$ & $\varepsilon 100^{\circ} 0$ & $6000^{\circ} 0$ & 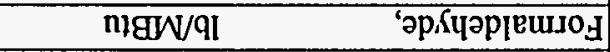 \\
\hline $860^{\circ} 0$ & $0+I^{\circ} 0$ & $\varepsilon Z I^{\circ} 0$ & ZLIO 0 & E9I'0 & $\angle t I^{\circ} 0$ & $80 I^{\circ} 0$ & EOI 0 & nggW/qI \\
\hline $62 I^{\circ} 0$ & $8 \angle 0^{\circ} 0$ & $\nabla L I^{\prime} 0$ & $t+0^{\circ} 0$ & $t S I^{\circ} 0$ & $\$ 6 Z^{\circ} 0$ & $\angle S 0^{\circ} 0$ & $660^{\circ} 0$ & 'Yead uniopinys - OD \\
\hline $6 Z I^{\circ} 0$ & ISO०0 & $0 \angle 0^{\circ} 0$ & $t+0^{\circ} 0$ & $\$ S 0^{\circ} 0$ & $080^{\circ} 0$ & $020^{\circ} 0$ & $090^{\circ} 0$ & 'วIEIS КpeวIS - OJ \\
\hline \multirow[t]{3}{*}{$96 \mathrm{I}$} & 6.91 & $2.8 I$ & $\tau^{\prime} 9 \mathrm{I}$ & $I L I$ & +61 & $S L I$ & S'SI & $20 \%$ \\
\hline & & & & & & & & :(s!seq K.up) po.rnseoW se suo!ss!̣ug seg \\
\hline & & & & & & & & \\
\hline $8-\mathrm{dr}$ & $8-\mathrm{dr}$ & $8-\mathrm{df}$ & $8-\mathrm{dr}$ & [อsว!] & [Dse! a] & [as?!a & [OSə!a & $\partial d K_{\mathrm{L}} \mid \partial n_{\mathrm{I}}$ \\
\hline $\mathrm{MOT} /-$ & पहै!H/MOT & MoT/MoT & पดे! & $48 ! \mathrm{H} / \mathrm{MO}^{-7}$ & 1107/- & $1107 / 1107$ & पริ!H/4รి!H & uo!!!puoj su!̣esodo səusng \\
\hline Y.LI & d.LI & $\mathrm{H} . \mathrm{II}$ & Y.LI & duI & Y.LI & X.LI & d.LI & $\partial \mathrm{d} K_{\mathrm{L}}$ JəuIng \\
\hline
\end{tabular}




\section{PERFORMANCE TEST REPORT - EXHAUST EMISSIONS FOR THE M-2 GASOLINE BURNER}

W. Litzke, Y. Celebi, and R. Mc Donald

August 1994

Energy Efficiency \& Conservation Division

Department of Applied Science

Brookhaven National Laboratory

Upton, New York 11973

This work was performed under the auspices of the U.S. Department of Energy Washington, D.C. Under Contract No. DE-AC02-76CH00016 


\section{TABLE OF CONTENTS}

SECTION PAGE

INTRODUCTION $\ldots \ldots \ldots \ldots \ldots \ldots \ldots \ldots \ldots \ldots \ldots$

1.1 Objective $\quad \ldots \ldots \ldots \ldots \ldots \ldots \ldots \ldots \ldots \ldots \ldots \ldots \ldots \ldots \ldots \ldots \ldots \ldots \ldots$

1.2 Background $\ldots \ldots \ldots \ldots \ldots \ldots \ldots \ldots \ldots \ldots \ldots \ldots \ldots \ldots \ldots \ldots \ldots$

1.3 Technical Approach $\ldots \ldots \ldots \ldots \ldots \ldots \ldots \ldots \ldots \ldots \ldots$

2.0 MEASUREMENT TECHNIQUE AND INSTRUMENTATION 2

2.1 Description of Burner and Test Operating Conditions ...... 2

2.2 Experimental Arrangement ................. 4

2.3 Flue Gas Analyses $\ldots \ldots \ldots \ldots \ldots \ldots \ldots \ldots \ldots$

2.4 Particulate Emissions $\ldots \ldots \ldots \ldots \ldots \ldots \ldots$

2.5 Formaldehyde $\ldots \ldots \ldots \ldots \ldots \ldots \ldots \ldots \ldots \ldots \ldots \ldots \ldots$

EXPERIMENTAL RESULTS $\ldots \ldots \ldots \ldots \ldots \ldots$

3.1 Emissions Measurements $\ldots \ldots \ldots \ldots \ldots \ldots$

4.0 GENERAL COMMENTS AND OBSERVATIONS . . . . . . 8

$5.0 \quad$ REFERENCES $\ldots \ldots \ldots \ldots \ldots \ldots \ldots \ldots \ldots \ldots \ldots \ldots \ldots$

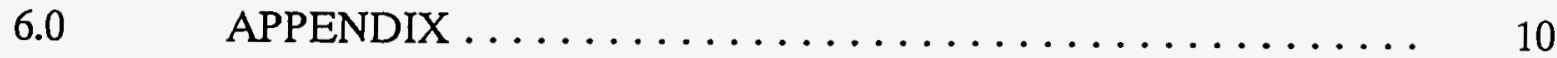

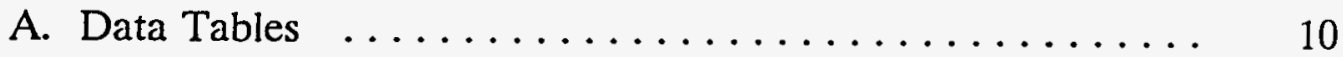




\section{LIST OF FIGURES}

FIGURES

PAGE

1 Schematic of Test Sampling System $\ldots \ldots \ldots \ldots \ldots \ldots$

$2 \quad$ Particulate Emissions Sampling System $\ldots \ldots \ldots \ldots \ldots \ldots$

3

Formaldehyde Sampling Train $\ldots \ldots \ldots \ldots \ldots \ldots \ldots$ 


\section{LIST OF TABLES}

TABLES PAGE

$1 \quad$ M-2 Test Conditions $\ldots \ldots \ldots \ldots \ldots \ldots \ldots \ldots \ldots \ldots \ldots$

2 Experimental Results for the $\mathrm{M}-2$ Burner $\ldots \ldots \ldots \ldots \ldots$ 


\subsection{INTRODUCTION}

\subsection{Objective}

The objective of this project is to provide data to the U.S. Army Natick RD\&E Center on the performance of three prototype burners, which have the capability of firing with multiple types of fuels (diesel and JP-8), and the conventional gasoline-fired M-2 burner. The prototype burners are intended to replace the $\mathrm{M}-2$ unit currently used in food cooking appliances in the Army. The burners supplied to Brookhaven National Laboratory (BNL) for the purpose of testing under this project included one M-2 unit, one M-3 prototype unit designed by Natick, one Babington prototype unit designed by Babington Engineering, and one ITR prototype designed by International Thermal Research Ltd. It should be noted, however, that after the project began, Babington Engineering provided an upgraded prototype unit for testing which replaced the unit initially provided by the Natick Center. The M-3 unit replaced the Karcher unit listed in the contract. These arrangements were agreed upon by the Army Project Officer and BNL at the outset of the experimental work.

The test procedures which were described in a Test Method Report allowed for the measurement of the concentrations of specific compounds emitted from the burners. These compounds included oxygen $\left(\mathrm{O}_{2}\right)$, carbon monoxide $(\mathrm{CO})$, oxides of nitrogen (NOx), formaldehyde, and particulate emissions. The level of smoke produced was also measured by using a Bacharach Smoke Number system (ASTM Standard D2156).

A performance test report has been prepared for each prototype burner that includes a description of the technology tested, a presentation of the results, and a discussion of practical observations about its operation and recommendations for improvements. This report details the results of the M-2 burner only. A comparison of results for all burners will be summarized in a separate report entitled, Comparison of Emissions Characteristics of Prototype Advanced Burners.

\subsection{Background}

The U.S. Army is currently interested in the development of advanced cooking appliances which can be fueled with distillate oil (diesel and JP-8) and deployed in the field. These appliance will be used in semi-enclosed areas and so it is important that the combustion process be consistently clean. Pollutants of potential concern include carbon monoxide, aldehydes, and particulates.

Federal agencies such as the Occupational Safety and Health Administration (OSHA) establish standards for permissible exposure limits to ensure that employees are not exposed to airborne concentrations of specific contaminants that exceed these limits. The current accepted exposure limit over an 8-hour period for $\mathrm{CO}$ is $50 \mathrm{ppm}$. The term "aldehydes" refers to a family of compounds with different levels of toxicity and concentration in combustion product exhaust. The dominant aldehyde in both exhaust products and the atmosphere is formaldehyde which has an 8 -hour average exposure limit of $0.75 \mathrm{ppm}$. In 
automotive engine exhaust the total hydrocarbon emissions can be in the 100's of ppm range and aldehydes may be about $1 / 3$ of the total. Nitrogen oxides generated from fuel oil combustion consist mostly of nitric oxide (NO) and nitrogen dioxide $\left(\mathrm{NO}_{2}\right)$ which have an 8-hour average exposure limit of $25 \mathrm{ppm}$ and a maximum limit of $5 \mathrm{ppm}$, respectively.

\subsection{Technical Approach}

In this project BNL has performed evaluation tests on prototype burners in support of the Army's efforts to develop advanced field cooking equipment. The basic test arrangement that was used is illustrated in Figure 1. All combustion products from the cooking appliance or prototype burner were collected in a hood and dilution tunnel arrangement. The flow in the dilution tunnel includes both combustion products and room air. The concentration of all pollutants was measured directly in the tunnel and, using fuel analyses information, the amount emitted was be related to the mass of fuel used. The burner fuel flow rate was measured and pollutant emissions are reported on: as measured, corrected to fixed excess air, mass/hour, mass per mass of fuel, and mass per unit of fuel heating value basis.

Testing during steady state operation consisted of turning the unit on, allowing it to run for the duration of the sampling time and then turning the unit off. For units that required a significant warmup period and did not readily ignite, such as the M2 and M3 units, steady state operation consisted of only the duration when the unit was firing stably. The long outdoor start-up period precludes any detailed transient measurements. For the ITR and Babington units, the start-up and shutdown emissions (transients) were also characterized. Clean transient operation is likely to lead to lower maintenance needs in the long term.

The fuels used in these tests consist of diesel (grade D-2), a kerosine type jet fuel (grade JP-8), and automotive gasoline. D-2 diesel has been specifically formulated for testing of equipment and is commonly used as a standard for testing mobile engines; JP-8 meets military specification MIL-T-83133. An analysis for each of these fuels was provided by Phillips 66 Company and they are included in the appendix of this report. The gasoline used for the M-2 burner was an unleaded regular grade of fuel.

\subsection{MEASUREMENT TECHNIQUE AND INSTRUMENTATION}

\subsection{Description of Burner and Test Operating Conditions}

The M-2 burner operates from a pressurized tank system containing a mixture of compressed air and gasoline. A preheater draws the fuel and air from the tank which is manually lit for burner start-up. The flame produced is aimed at the generator tube to preheat and vaporize the fuel for start-up. Fuel in the form of vapor is released through slotted cast iron sections of the burner assembly which is then ignited by the preheater. By adjusting the air shutter a good fuel/air mixture can be set to produce a flame that is stabilized. The controls consist of the flame valve and air shutter which allow for adjustment 


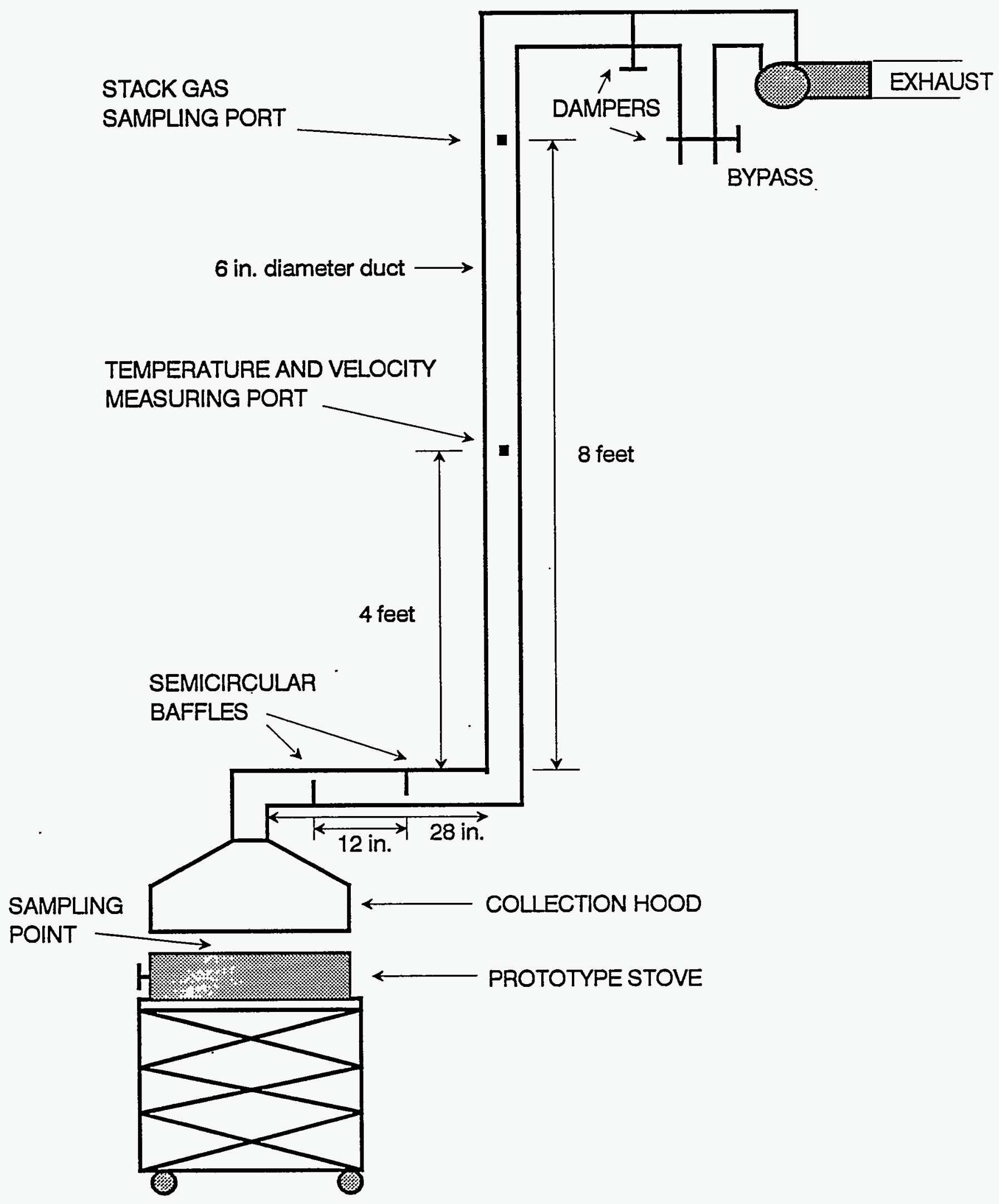

Figure 1. Schematic of Test Sampling System 
in the amount of fuel output and the amount of air in the mixture, respectively. The tank capacity is 2.1 gallons and operating pressure is between 6-25 psi. Because of the poor initial conditions for combustion during the start-up period and the resulting fumes produced, the unit must be lit and preheated outdoors. Once a steady blue flame is established the unit was brought indoors for the complete set of tests. A test sequence consists of the steady firing period and the shutdown period.

A set of tests was conducted to evaluate overall performance of the prototype burner, emissions characteristics, and general ease of operation with respect to changes in fuel firing rate. Gasoline was used to fuel all tests. Table 1 summarizes the operating conditions of the tests that were conducted.

\begin{tabular}{|c|c|c|c|c|}
\hline Test & Fuel Type & $\begin{array}{c}\text { Firing Rate } \\
(\mathrm{Btu} / \mathrm{hr})\end{array}$ & $\begin{array}{c}\text { Firing Rate } \\
(\mathrm{gph})\end{array}$ & Operating Mode \\
\hline HIGH & Gasoline & 63,000 & 0.51 & Steady State \\
\hline MID & Gasoline & 40,100 & 0.32 & Steady State \\
\hline LOW & Gasoline & 22,600 & 0.18 & Steady State \\
\hline
\end{tabular}

Table 1. M-2 Test Conditions

Each test ran for the duration of the sampling time which was about 100 minutes. The total sampling time allowed for an adequate amount of particulate matter and formaldehyde to be collected in the sampling trains and for observations to be made of the burner performance over this period. The particulate and formaldehyde concentrations determined, therefore, represent time-averaged values for this entire test.

\subsection{Experimental Arrangement}

The dilution tunnel system collects all of the combustion products emitted from the burner into the hood where they are also mixed with some room air which is also drawn in as well. By adjusting the dampers in the bypass system the induced draft could be adjusted such that the amount of dilution with room air was minimized. Thermocouples were set up along the 6 in. diameter duct at the sampling ports to measure stack gas temperatures. The centerline flue gas velocity was measured with a pitot tube upstream of the stack gas sampling port.

\subsection{Flue Gas Analyses}

In the dilution tunnel oxygen content (O2) of the flue gas, carbon monoxide (CO) and oxides of nitrogen (NOx) were measured in real-time during each test. The oxygen content which was measured with a paramagnetic analyzer (Beckman Model 755) was used to determine the excess air level. Carbon monoxide was measured with an infrared analyzer 
(Rosemount Analytical Model 880). $\mathrm{NO}_{\mathrm{X}}$ was measured with a chemiluminescent analyzer (Beckman Model 955). A value reported for the CO during startup or shutdown represents the peak value observed during the transient period; the steady state value represents the average number during the firing period. NOx generally increases during startup, reaches a steady level, and then decreases at shutdown; the values reported represent the average steady state concentrations. CO and NOx concentrations are presented in parts per million $(\mathrm{ppm})$, and $\mathrm{O} 2$ in $\%$ by volume of stack gas. By convention and for comparison emissions from stationary combustion choices are generally corrected for the differences in excess air and are represented at fixed $3 \% \mathrm{O} 2$.

A different approach was used to determine particulate and aldehyde emissions which provided a good measurement for these contaminants at low concentrations. The methods which will be described in further detail in the following sections require that integrated samples of flue gas be collected and then analyzed. In this manner, average emissions are determined for these contaminants over the entire test sequence.

\subsection{Particulate Emissions}

Particulate emissions is determined by the amount of material collected, by weight, on a glass fiber filter from the volume of flue gas sampled. The flue gas was sampled directly from the dilution tunnel with a standard EPA Method 5 sampling train [1]. The sampling train, shown in Figure 2, consists of a stainless steel nozzle and filter holder with a preweighed glass fiber filter, a set of glass impingers kept at $32 \mathrm{~F}(0 \mathrm{C})$, a sampling pump, and a dry gas meter that measures the volume of dry gas sampled. The filter remains at the same temperature as the flue gas at the sampling point, which in these test cases is above the water or sulfuric acid dew point. The filter catch and materials washed from the nozzle probe were weighed to obtain the total particulates collected.

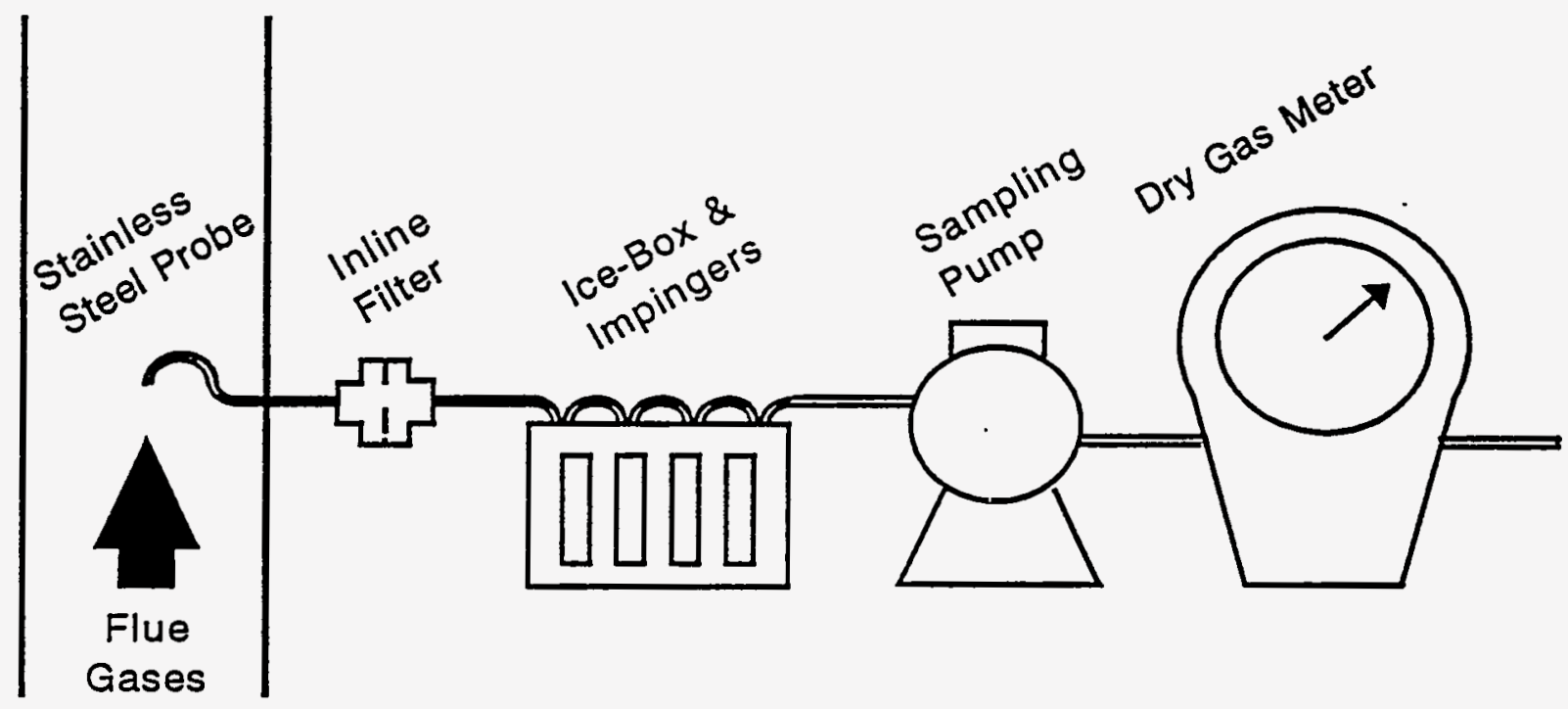

Figure 2. Particulate Emissions Sampling System 


\subsection{Formaldehyde}

A simple and quick, colorimetric method of analysis was used to determine formaldehyde concentrations which was derived from NIOSH Method 3500 [2]. This standard provides a monitoring method that applies to occupational exposure to airborne formaldehyde in the work area. It was used in these tests to draw samples directly from the dilution tunnel to obtain maximum possible contaminant levels in the stack gas. The sampling setup for these measurements is shown in Figure 3. Gas samples were bubbled through a set of glass impingers containing sodium bisulfite solution where formaldehyde is absorbed. A reaction of this solution with chromotropic acid and sulfuric acid yields a product that absorbs in the visible spectrum at $580 \mathrm{~nm}$ wavelength. Determination of formaldehyde concentrations is based on the absorbance measured.

Since this method is used to measure exposure levels at ambient temperatures a glass heat exchanger was added to the standard sampling train so that the sampled gas, which was typically above $300 \mathrm{~F}$, was allowed to cool to about $70 \mathrm{~F}$ before entering the sample impingers.

A maximum sample of $3.53 \mathrm{ft}^{3}$ (100 liters) collected gives a detection level as low as $0.02 \mathrm{ppm}$. A test run for 100 minutes at 1 liter $/ \mathrm{min}$ sampling rate provides the time-weighted average concentration of formaldehyde for that period of time. Since most of the pollutants were emitted during the transient period (ie. startup), which usually lasts for about 1-2 minutes, the actual peak concentrations would be somewhat higher than the average value. An estimate of peak concentrations was obtained by cycling the burner such that enough gas is sampled during startups and shutdowns over successive cycles to do the analysis.

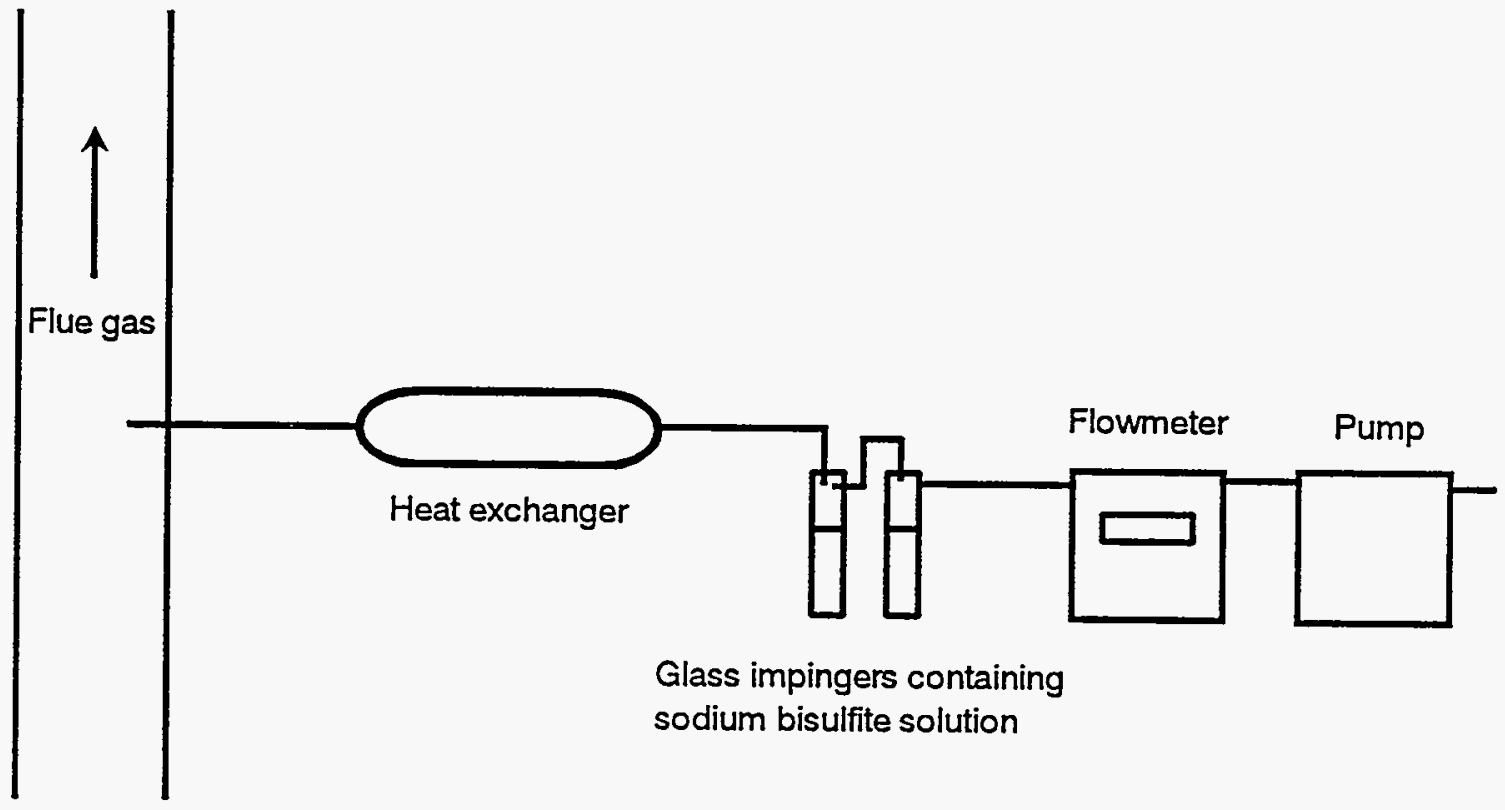

Figure 3. Formaldehyde Sampling Train 


\subsection{EXPERIMENTAL RESULTS}

\subsection{Emissions Measurements}

Refer to Table 2 for the experimental results obtained for emissions during typical stove operation. Values for carbon monoxide (CO), oxides of nitrogen (NOx) and oxygen content $(\% \mathrm{O} 2)$ have been provided on an "as measured basis" which are direct readings of the flue gas measurements taken from the dilution tunnel, and emissions corrected to $3 \%$ oxygen content. The corrected values provide a common basis for comparison among different burners and different modes of operation. However, it could be reasonable to say that the

\begin{tabular}{|c|c|c|c|}
\hline Burner Type & $\mathrm{M} 2$ & $\mathrm{M} 2$ & $\mathrm{M} 2$ \\
\hline Burner Operating Condition & High & Mid & Low \\
\hline Fuel Type & Gasoline & Gasoline & Gasoline \\
\hline \multicolumn{4}{|l|}{ Gas Emissions as Measured (dry basis): } \\
\hline CO - startup peak, $\quad$ ppm & NA & NA & NA \\
\hline CO - steady state, $\quad$ ppm & 48 & 13 & 10 \\
\hline CO - shutdown peak, & 46 & 13 & 10 \\
\hline NOx & 7 & 9 & $\mathrm{NA}$ \\
\hline$\% \mathrm{O} 2$ & 16 & 17.2 & 19.1 \\
\hline \multicolumn{4}{|l|}{ Emissions corrected to $3 \% \mathrm{O} 2$} \\
\hline CO - startup, $\quad$ ppm & & & \\
\hline CO - steady state, & 173 & 62 & 95 \\
\hline CO - shutdown peak, & 166 & 62 & 95 \\
\hline $\begin{array}{ll}\mathrm{NOx} & \mathrm{ppm} \\
\end{array}$ & 25 & 43 & $\mathrm{NA}$ \\
\hline \multicolumn{4}{|l|}{ Particulate Measurements } \\
\hline $\begin{array}{l}\text { Concentration of particulates in } \\
\text { stack gas, dry basis, } \mathrm{mg} / \mathrm{dscf}\end{array}$ & 0.032 & 0.087 & 0.075 \\
\hline $\begin{array}{l}\text { Total particulates emitted, } \\
\text { lb/ } 100 \mathrm{lb} \text { fuel }\end{array}$ & 0.005 & 0.017 & 0.025 \\
\hline Total particulates emitted, & 76 & 149 & 125 \\
\hline Total particulates emitted, $\quad \mathrm{lb} / \mathrm{MBtu}$ & 0.003 & 0.008 & 0.012 \\
\hline \multicolumn{4}{|l|}{ Formaldehyde Measurements } \\
\hline $\begin{array}{l}\text { Measured concentration of formaldehyde } \\
\text { in stack, ppm }\end{array}$ & 0.75 & 1.54 & 1.17 \\
\hline $\begin{array}{l}\text { Concentration of formaldehyde } \\
\text { corrected to } 3 \% \mathrm{O} 2, \quad \mathrm{ppm}\end{array}$ & 2.7 & 7.3 & 11.1 \\
\hline
\end{tabular}

Table 2. Experimental Results for the M-2 Burner 
"as measured" values are maximum concentrations that would be observed when the stoves are operating under steady state conditions in an open system in which the ambient air provides the dilution.

As previously stated, no data was collected during start-up. Operation at steady state gives $\mathrm{CO}$ levels from 10-48 ppm (at high oxygen levels) and 62-173 ppm @ 3\% O2. The levels do not increase during the shutdown periods. The values reported for NOx are the average observed values during the steady firing period. Data for the middle and high firing rates shows relatively low concentrations.

The results of particulate emissions are given in several different units. The most common expressions are in the form of mass of pollutant/ mass of fuel, or mass of pollutant/ energy input. To convert from the measured stack gas concentration to these units the measured oxygen content of flue gas and an assumed typical fuel composition (for gasoline) were used to determine the excess air and the total flue gas flowrate. The results of all calculations are found in the appendix. The amount of particulates emitted as reported are averaged values for the test sequence - steady firing, and shutdown which totals to a sampling period of about 100 minutes. Particulate emissions varied from 0.003 to $0.012 \mathrm{lb} /$ million Btu over the full firing range. Particulate concentrations seem to increase with lower firing rates.

A summary of the formaldehyde measurements is shown with values on an "as measured basis" which are the average stack concentrations, and with values that were corrected to $3 \%$ O2. Stack emissions show that the M-2 unit can exceed the permissible worker exposure limit of $0.75 \mathrm{ppm}$, specifically in the low and middle firing rates.

\subsection{GENERAL COMMENTS AND OBJECTIVES}

The unit tested was a standard M-2 unit supplied by Natick RD\&E to BNL for testing. The unit and its characteristics are assumed to be well documented by the U.S. Army. BNL's general comments and observations are brief for this reason.

The unit functioned as expected. The burner operation is simple and depends on a well trained operator. The operation is based on manual control during the mandatory outdoor start-up phase and also during steady burning conditions during use in cooking (indoors or outdoors). During start-up the system initially produces heavy (visible) levels of smoke. The steady burn emission characteristics have already been discussed.

Due to the nature of the fuel (gasoline) the system must be handled with great care and careful attention to detail. The potential for serious problems based on failure to follow proper operating procedures is very high.

The current Natick development project which is intended to result in the replacement of the M-2 unit with a battery powered system capable of firing either Diesel or JP-8 fuel should negate many potential operator related issues. Fuel handling, transfer, and filling will certainly be safer based on the nature of the fuel properties. 


\subsection{REFERENCES}

[1] EPA Code of Federal Regulations, 40 CFR Part 60, Appendix A, Method 5, 1990.

[2] National Institute for Occupational Safety and Health, NIOSH Manual of Analytical Methods, Third edition, 1989. 


\subsection{APPENDIX}

\section{A. Data Tables}

This section contains information on the operating parameters recorded during each set of tests, fuel composition, measured and calculated data to determine emission factors. Results have been provided for gasoline fuel. 


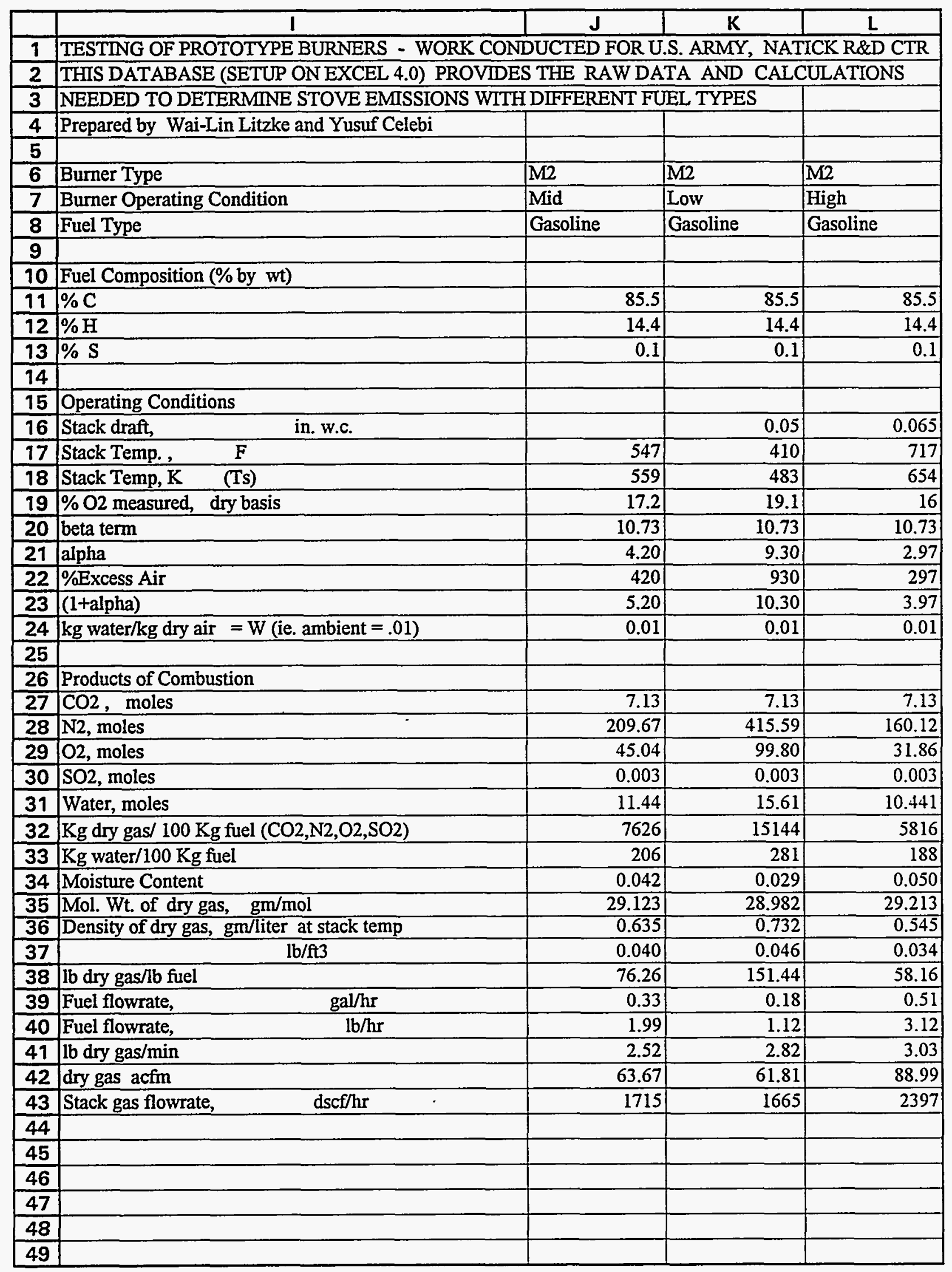


DATA FOR THE M-2 UNIT - GASOLINE FUEL

\begin{tabular}{|c|c|c|c|c|}
\hline & 1 & $\mathbf{J}$ & $\mathrm{K}$ & $\mathbf{L}$ \\
\hline 50 & Gas Emissions as Measured (dry basis): & & & \\
\hline 51 & CO - startup peak, $\quad$ ppm & NA & NA & NA \\
\hline 52 & CO - steady state, & 13 & 10 & 48 \\
\hline 53 & CO - shutdown peak, ppm & 13 & 10 & 46 \\
\hline 54 & NOx & 9 & & 7 \\
\hline 55 & $\% \mathrm{O} 2$ & 17.2 & 19.1 & 16 \\
\hline \multicolumn{5}{|l|}{56} \\
\hline 57 & Particulate Measurements & & & \\
\hline 58 & Total amount collected, $\mathrm{gm}$ & 0.0054 & 0.0047 & 0.0018 \\
\hline 59 & Temp. at meter, $\mathrm{F}$ & 73.7 & 76.2 & 74.6 \\
\hline 60 & Dry gas volume sampled, $\quad$ dcf & 62.9 & 63.445 & 57.206 \\
\hline 61 & Dry gas volume sampled, std. cond., dscf & 62.228 & 62.475 & 56.500 \\
\hline 62 & $\begin{array}{l}\text { Concentration of particulates in stack gas, } \\
\text { basis, } \quad \mathrm{mg} / \mathrm{dscf}\end{array}$ & 0.087 & 0.075 & 0.032 \\
\hline \multicolumn{5}{|c|}{, } \\
\hline 64 & Formaldehyde Measurements & & & \\
\hline 65 & Total mass collected, ug & 174.2 & 137.8 & 81.2 \\
\hline 66 & Volume sampled, (std. liters) & 92 & 96 & 87.86 \\
\hline 67 & Concentration in vol. sampled, $\mathrm{mg} / \mathrm{scm}$ & 1.893 & 1.435 & 0.924 \\
\hline 68 & $\mathrm{mg} / \mathrm{scf}$ & 0.054 & 0.041 & 0.026 \\
\hline 69 & Total formaldehyde emitted, $\quad \mathrm{lb} / \mathrm{lb}$ fuel & 0.000101975 & 0.000133271 & $4.42413 \mathrm{E}-05$ \\
\hline 70 & Concentration of formald. in stack, $\mathrm{ppm}$ & 1.543 & 1.170 & 0.753 \\
\hline 71 & & & & \\
\hline
\end{tabular}




\title{
PERFORMANCE TEST REPORT - EXHAUST EMISSIONS \\ FOR THE M-3 MULTIFUEL BURNER
}

\author{
W. Litzke, Y. Celebi, and R. Mc Donald
}

August 1994

\section{Energy Efficiency \& Conservation Division Department of Applied Science Brookhaven National Laboratory Upton, New York 11973}

This work was performed under the auspices of the U.S. Department of Energy Washington, D.C. Under Contract No. DE-AC02-76CH00016 


\section{TABLE OF CONTENTS}

1.1 Objective $\quad \ldots \ldots \ldots \ldots \ldots \ldots \ldots \ldots \ldots \ldots \ldots \ldots \ldots \ldots \ldots \ldots$

1.2 Background $\ldots \ldots \ldots \ldots \ldots \ldots \ldots \ldots \ldots \ldots \ldots \ldots$

1.3 Technical Approach $\ldots \ldots \ldots \ldots \ldots \ldots \ldots \ldots \ldots . \ldots \ldots$

2.0 MEASUREMENT TECHNIQUE AND INSTRUMENTATION

2.1 Description of Burner and Test Operating Conditions ...... 2

2.2 Experimental Arrangement .............. 4

2.3 Flue Gas Analyses $\ldots \ldots \ldots \ldots \ldots \ldots \ldots \ldots \ldots$

2.4 Particulate Emissions $\ldots \ldots \ldots \ldots \ldots \ldots \ldots \ldots \ldots \ldots$

2.5 Formaldehyde $\ldots \ldots \ldots \ldots \ldots \ldots \ldots \ldots \ldots \ldots \ldots$

3.0 EXPERIMENTAL RESULTS $\ldots \ldots \ldots \ldots \ldots \ldots \ldots \ldots$

3.1 Emissions Measurements $\ldots \ldots \ldots \ldots \ldots \ldots \ldots \ldots \ldots$

4.0 GENERAL COMMENTS AND OBSERVATIONS ........ 9

$5.0 \quad$ REFERENCES $\ldots \ldots \ldots \ldots \ldots \ldots \ldots \ldots \ldots \ldots \ldots \ldots \ldots \ldots$

6.0 APPENDIX $\ldots \ldots \ldots \ldots \ldots \ldots \ldots \ldots \ldots \ldots \ldots \ldots \ldots \ldots \ldots \ldots \ldots$

A. Fuels Analyses $\ldots \ldots \ldots \ldots \ldots \ldots \ldots \ldots \ldots \ldots \ldots \ldots \ldots$

B. Data Tables $\ldots \ldots \ldots \ldots \ldots \ldots \ldots \ldots \ldots \ldots \ldots \ldots \ldots \ldots$ 


\section{LIST OF FIGURES}

FIGURES

PAGE

1

2

3
Schematic of Test Sampling System

Particulate Emissions Sampling System $\ldots \ldots \ldots \ldots \ldots \ldots$. 6

Formaldehyde Sampling Train $\ldots \ldots \ldots \ldots \ldots \ldots \ldots$ 


\section{LIST OF TABLES}

$\begin{array}{ll}\text { TABLES PAGE } & \text { PAT }\end{array}$

$1 \quad$ M-3 Unit Test Conditions $\ldots \ldots \ldots \ldots \ldots \ldots \ldots \ldots \ldots \ldots$

$2 \quad$ M-3 Unit - Carbon Monoxide, Nitrogen Oxides and

Oxygen Content ....................... 8

3 M-3 Unit - Particulate Emissions $\ldots \ldots \ldots \ldots \ldots \ldots \ldots \ldots$

$4 \quad$ M-3 Unit - Formaldehyde Emissions $\ldots \ldots \ldots \ldots \ldots \ldots \ldots \ldots$ 


\subsection{INTRODUCTION}

\subsection{Objective}

The objective of this project is to provide data to the U.S. Army Natick RD\&E Center on the performance of three prototype burners, which have the capability of firing with multiple types of fuels (diesel and JP-8), and the conventional gasoline-fired M-2 burner. The prototype burners are intended to replace the M-2 unit currently used in food cooking appliances in the Army. The burners supplied to Brookhaven National Laboratory (BNL) for the purpose of testing under this project included one M-2 unit, one M-3 prototype unit designed by Natick, one Babington prototype unit designed by Babington Engineering, and one ITR prototype designed by International Thermal Research Ltd. It should be noted, however, that after the project began, Babington Engineering provided an upgraded prototype unit for testing which replaced the unit initially provided by the Natick Center. The M-3 unit replaced the Karcher unit listed in the contract. These arrangements were agreed upon by the Army Project Officer and BNL at the outset of the experimental work.

The test procedures which were described in a Test Method Report allowed for the measurement of the concentrations of specific compounds emitted from the burners. These compounds included oxygen $\left(\mathrm{O}_{2}\right)$, carbon monoxide $(\mathrm{CO})$, oxides of nitrogen $(\mathrm{NOx})$, formaldehyde, and particulate emissions. The level of smoke produced was also measured by using a Bacharach Smoke Number system (ASTM Standard D2156).

A performance test report has been prepared for each prototype burner that includes a description of the technology tested, a presentation of the results, and a discussion of practical observations about its operation and recommendations for improvements. This report details the results of the M-3 burner only. A comparison of results for all burners will be summarized in a separate report entitled, Comparison of Emissions Characteristics of Prototype Advanced Burners.

\subsection{Background}

The U.S. Army is currently interested in the development of advanced cooking appliances which can be fueled with distillate oil (diesel and JP-8) and deployed in the field. These appliance will be used in semi-enclosed areas and so it is important that the combustion process be consistently clean. Pollutants of potential concern include carbon monoxide, aldehydes, and particulates.

Federal agencies such as the Occupational Safety and Health Administration (OSHA) establish standards for permissible exposure limits to ensure that employees are not exposed to airborne concentrations of specific contaminants that exceed these limits. The current accepted exposure limit over an 8-hour period for $\mathrm{CO}$ is $50 \mathrm{ppm}$. The term "aldehydes" refers to a family of compounds with different levels of toxicity and concentration in combustion product exhaust. The dominant aldehyde in both exhaust products and the atmosphere is formaldehyde which has an 8-hour average exposure limit of $0.75 \mathrm{ppm}$. In 
automotive engine exhaust the total hydrocarbon emissions can be in the 100's of ppm range and aldehydes may be about $1 / 3$ of the total. Nitrogen oxides generated from fuel oil combustion consist mostly of nitric oxide (NO) and nitrogen dioxide $\left(\mathrm{NO}_{2}\right)$ which have an 8-hour average exposure limit of $25 \mathrm{ppm}$ and a maximum limit of $5 \mathrm{ppm}$, respectively.

\subsection{Technical Approach}

In this project BNL has performed evaluation tests on prototype burners in support of the Army's efforts to develop advanced field cooking equipment. The basic test arrangement that was used is illustrated in Figure 1. All combustion products from the cooking appliance or prototype burner were collected in a hood and dilution tunnel arrangement. The flow in the dilution tunnel includes both combustion products and room air. The concentration of all pollutants was measured directly in the tunnel and, using fuel analyses information, the amount emitted was be related to the mass of fuel used. The burner fuel flow rate was measured and pollutant emissions are reported on: as measured, corrected to fixed excess air, mass/hour, mass per mass of fuel, and mass per unit of fuel heating value basis.

Testing during steady state operation consisted of turning the unit on, allowing it to run for the duration of the. sampling time and then turning the unit off. For units that required a significant warmup period and did not readily ignite, such as the M2 and M3 units, steady state operation consisted of only the duration when the unit was firing stably. The long outdoor start-up period precludes any detailed transient measurements. For the ITR and Babington units, the start-up and shutdown emissions (transients) were also characterized. Clean transient operation is likely to lead to lower maintenance needs in the long term.

The fuels used in these tests consist of diesel (grade D-2), a kerosine type jet fuel (grade JP-8), and automotive gasoline. D-2 diesel has been specifically formulated for testing of equipment and is commonly used as a standard for testing mobile engines; JP-8 meets military specification MIL-T-83133. An analysis for each of these fuels was provided by Phillips 66 Company and they are included in the appendix of this report. The gasoline used for the M-2 burner was an unleaded regular grade of fuel.

\subsection{MEASUREMENT TECHNIQUE AND INSTRUMENTATION}

\subsection{Description of Burner and Test Operating Conditions}

The M-3 burner operates from a pressurized tank system containing a mixture of compressed air and fuel. A preheater assembly draws the fuel and air from the tank which is manually lit for burner start-up. The flame produced is aimed at the vaporizer assembly to preheat and vaporize the fuel for start-up. Fuel in the form of vapor is sprayed through a nozzle located in the burner head assembly which is then ignited by the preheater. By adjusting the air shutter the fuel/air mixture can be set to produce a flame that is stabilized on the flame holder. The control assembly consists of the flame control and air shutter 


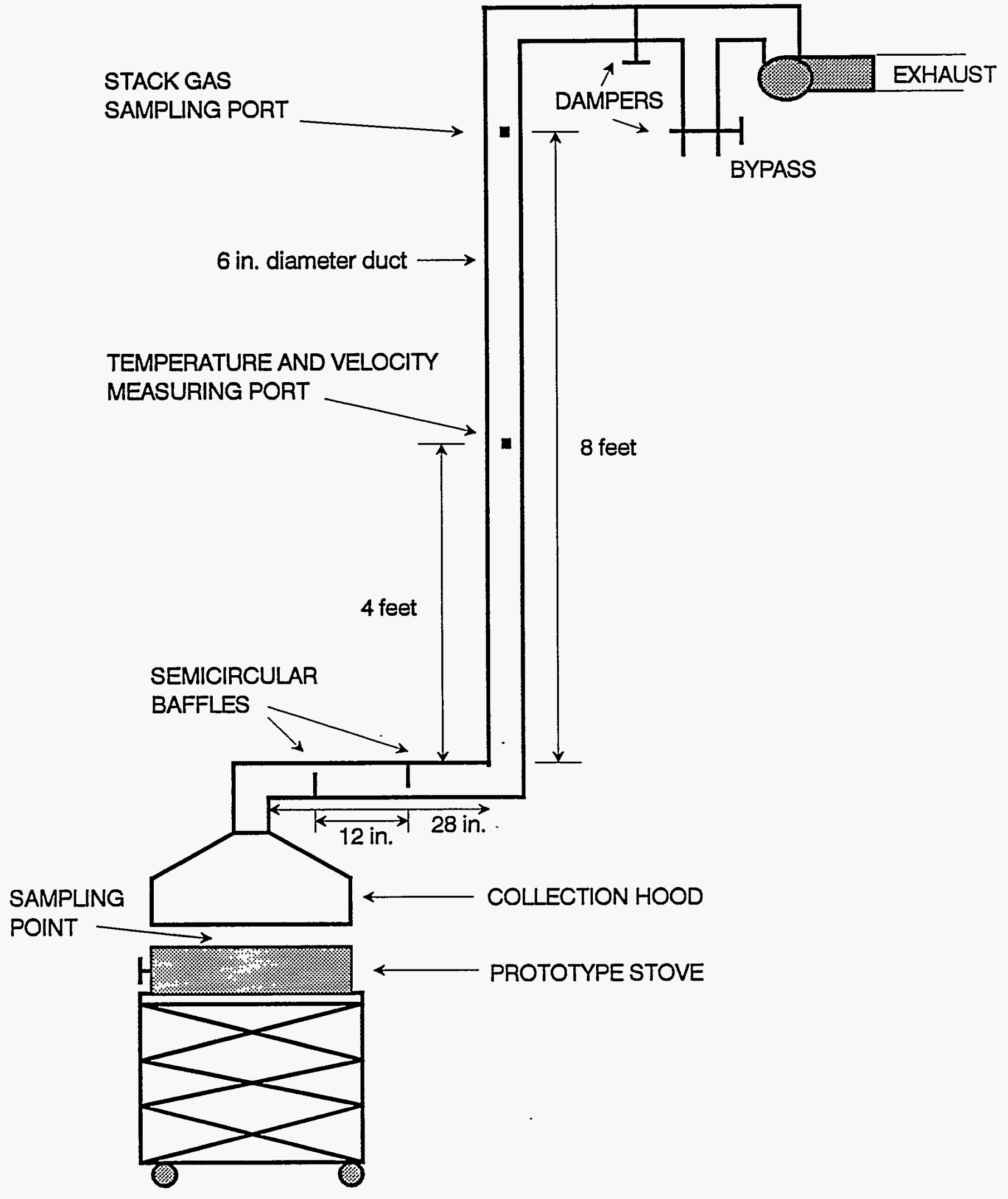

Figure 1. Schematic of Test Sampling System 
control which allows for adjustment in the amount of fuel output (HIGH and LOW ) and the amount of air in the mixture, respectively. The tank capacity is 2.1 gallons and operating pressure is between $25-35$ psi. Because of the poor initial combustion conditions during the start-up period and the resulting fumes produced, the unit must be lit and preheated outdoors. Once a steady blue flame is established the unit was brought indoors for the complete set of tests. A test sequence consists of the steady firing period and the shutdown period.

A set of tests was conducted to evaluate overall performance of the prototype burner, emissions characteristics, and general ease of operation with respect to changes in fuel firing rate. Diesel fuel was used in all tests. It should be noted that in the original Statement of Work the M-3 unit was to be tested with JP-8 fuel also. However, a defect noticed in the equipment created a potential hazard which prevented further testing. A pin-hole was found on the superheater connecting to the vaporizer where a vapor leak was clearly indicated. Table 1 summarizes the operating conditions of each test.

\begin{tabular}{|c|c|c|c|c|}
\hline Test & Fuel Type & $\begin{array}{c}\text { Firing Rate } \\
\text { (Btu/hr) }\end{array}$ & $\begin{array}{c}\text { Firing } \\
\text { Rate } \\
(\mathrm{gph})\end{array}$ & $\begin{array}{c}\text { Operating } \\
\text { Mode }\end{array}$ \\
\hline HIGH & Diesel & 59,000 & 0.44 & Steady State \\
\hline LOW & Diesel & 28,200 & 0.21 & Steady State \\
\hline
\end{tabular}

Table 1. M-3 Test Conditions

Each test ran for the duration of the sampling time which was about 100 minutes. The total sampling time allowed for an adequate amount of particulate matter and formaldehyde to be collected in the sampling trains as well as allowed observations to be made of the burner performance over this period. The particulate and formaldehyde concentrations determined, therefore, represent time-averaged values for this entire test.

\subsection{Experimental Arrangement}

The dilution tunnel system collects all of the combustion products emitted from the burner into the hood where they are also mixed with some room air which is also drawn in as well. By adjusting the dampers in the bypass system the induced draft could be adjusted such that the amount of dilution with room air was minimized. Thermocouples were set up along the 6 in. diameter duct at the sampling ports to measure stack gas temperatures. The centerline flue gas velocity was measured with a pitot tube upstream of the stack gas sampling port. 


\subsection{Flue Gas Analyses}

In the dilution tunnel oxygen content $(\mathrm{O} 2)$ of the flue gas, carbon monoxide $(\mathrm{CO})$ and oxides of nitrogen (NOx) were measured in real-time during each test. The oxygen content which was measured with a paramagnetic analyzer (Beckman Model 755) was used to determine the excess air level. Carbon monoxide was measured with an infrared analyzer (Rosemount Analytical Model 880) . $\mathrm{NO}_{\mathrm{X}}$ was measured with a chemiluminescent analyzer (Beckman Model 955). A value reported for the $\mathrm{CO}$ during startup or shutdown represents the peak value observed during the transient period; the steady state value represents the average number during the firing period. NOx generally increases during startup, reaches a steady level, and then decreases at shutdown; the values reported represent the average steady state concentrations. $\mathrm{CO}$ and NOx concentrations are presented in parts per million (ppm), and $\mathrm{O} 2$ in $\%$ by volume of stack gas. By convention and for comparison emissions from stationary combustion choices are generally corrected for the differences in excess air and are represented at fixed $3 \% \mathrm{O} 2$.

A different approach was used to determine particulate and aldehyde emissions which provided a good measurement for these contaminants at low concentrations. The methods which will be described in further detail in the following sections require that integrated samples of flue gas be collected and then analyzed. In this manner, average emissions are determined for these contaminants over the entire test sequence.

\subsection{Particulate Emissions}

Particulate emissions were determined by the amount of material collected, by weight, on a glass fiber filter from the volume of flue gas sampled. The flue gas was sampled directly from the dilution tunnel with a standard EPA Method 5 sampling train [1]. The sampling train, shown in Figure 2, consists of a stainless steel nozzle and filter holder with a preweighed glass fiber filter, a set of glass impingers kept at $32^{\circ} \mathrm{F}(0 \mathrm{C})$, a sampling pump, and a dry gas meter that measures the volume of dry gas sampled. The filter remains at the same temperature as the flue gas at the sampling point, which in these test cases is above the water or sulfuric acid dew point. The filter catch and materials washed from the nozzle probe were weighed to obtain the total particulates collected.

\subsection{Formaldehyde}

A simple and quick, colorimetric method of analysis was used to determine formaldehyde concentrations which was derived from NIOSH Method 3500 [2]. This standard provides a monitoring method that applies to occupational exposure to airborne formaldehyde in the work area. It was used in these tests to draw samples directly from the dilution tunnel to obtain maximum possible contaminant levels in the stack gas. The sampling setup for these measurements is shown in Figure 3. Gas samples were bubbled through a set of glass impingers containing sodium bisulfite solution where formaldehyde is absorbed. A reaction of this solution with chromotropic acid and sulfuric acid yields a product that absorbs in the 
visible spectrum at $580 \mathrm{~nm}$ wavelength. Determination of formaldehyde concentrations is based on the absorbance measured.

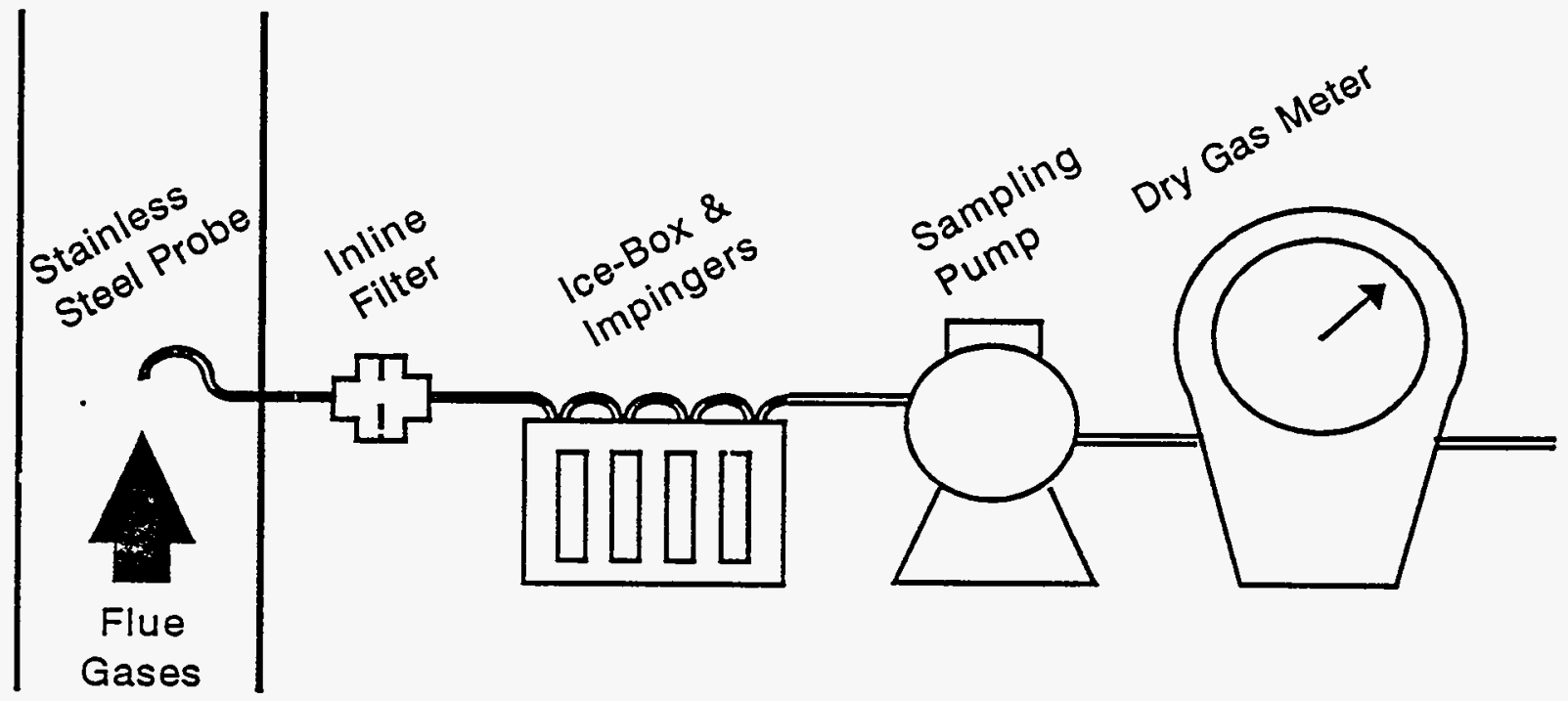

Figure 2. Particulate Emissions Sampling System

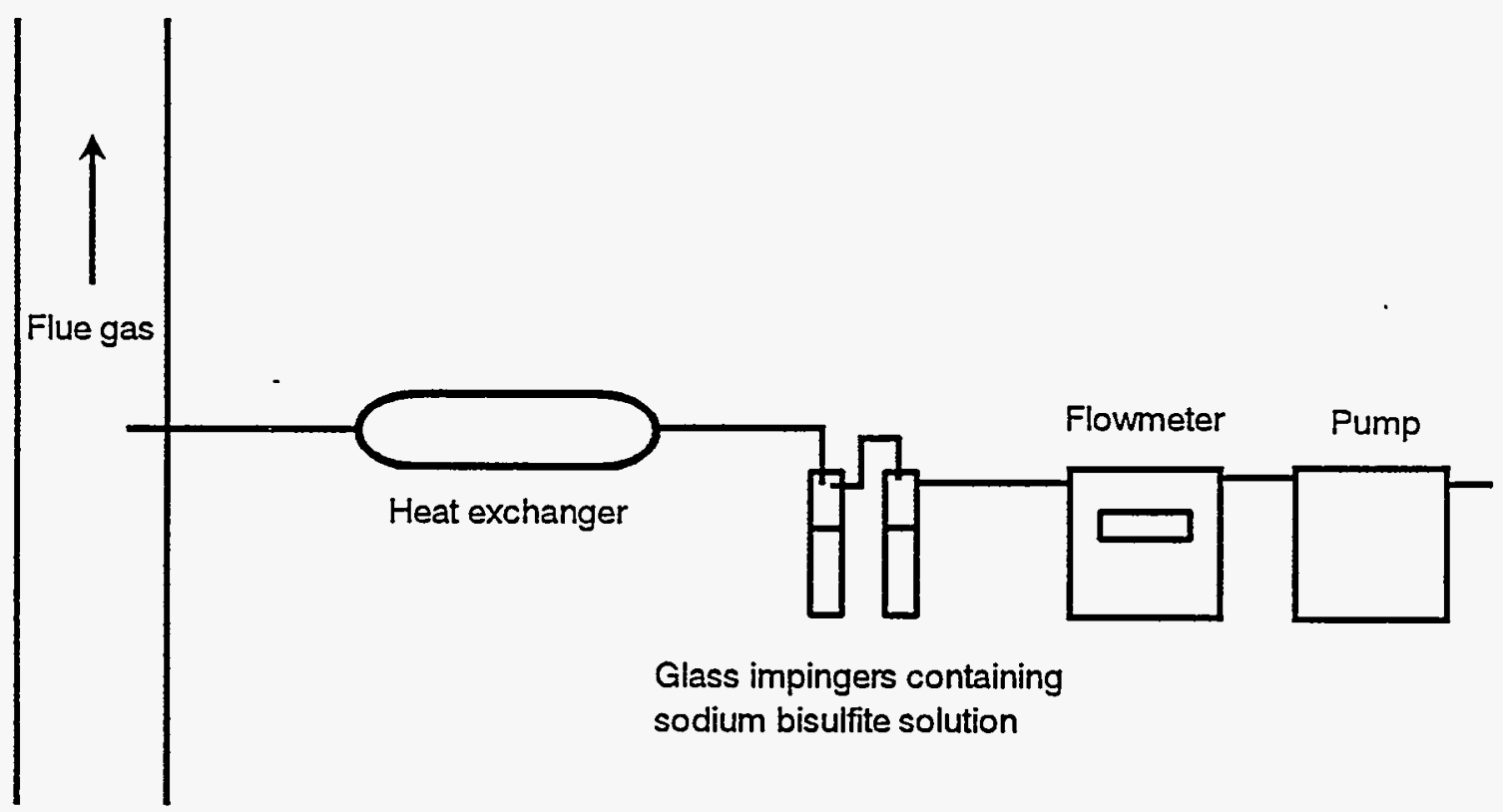

Figure 3. Formaldehyde Sampling Train 
Since this method is used to measure exposure levels at ambient temperatures a glass heat exchanger was added to the standard sampling train so that the sampled gas, which was typically above $300^{\circ} \mathrm{F}$, was allowed to cool to about $70^{\circ} \mathrm{F}$ before entering the sample impingers.

A maximum sample of $3.53 \mathrm{ft}^{3}$ (100 liters) collected gives a detection level as low as $0.02 \mathrm{ppm}$. A test run for 100 minutes at 1liter $/ \mathrm{min}$ sampling rate provides the time-weighted average concentration of formaldehyde for that period of time. Since most of the pollutants were emitted during the transient period (i.e. startup), which usually lasts for about 1-2 minutes, the actual peak concentrations would be somewhat higher than the average value. An estimate of peak concentrations was obtained by cycling the burner such that enough gas is sampled during startups and shutdowns over successive cycles to do the analysis.

\subsection{EXPERIMENTAL RESULTS}

\subsection{Emissions Measurements}

Refer to Table 2 for some of the experimental results obtained for gaseous emissions during typical stove operation. Values for carbon monoxide (CO), oxides of nitrogen (NOx) and oxygen content (\%.O2) have been provided on an "as measured basis" which are direct readings of the flue gas measurements taken from the dilution tunnel, and emissions corrected to $3 \%$ oxygen content. The corrected values provide a common basis for comparison among different burners and different modes of operation. However, it could be reasonable to say that the "as measured" values are maximum concentrations that would be observed when the stoves are used in an open system in which the ambient air provides the dilution.

As previously stated, no data was collected during start-up. Operation at steady state gives CO levels from 10-25 ppm (at almost ambient oxygen levels) and 100-196 ppm @ 3\% $\mathrm{O} 2$. The levels do not increase during the shutdown periods. The values reported for NOx are the average observed during the steady firing period.

The results of particulate emissions are shown in Table 3 and are given in several different units. The most common expressions are in the form of mass of pollutant per mass of fuel, or mass of pollutant per energy input. To convert from the measured stack gas concentration to these units the measured oxygen content of flue gas and an assumed typical fuel composition (for diesel) were used to determine the excess air and the total flue gas flowrate. The results of all calculations are found in the appendix. The amount of particulates emitted as reported are averaged values for the test sequence - steady firing, and shutdown which totals to a sampling period of about 100 minutes. Particulate emissions were about $0.019 \mathrm{lb} /$ million Btu for the M-3 unit for low and high firing rates. 


\begin{tabular}{|c|c|c|}
\hline Burner Type & M3 & M3 \\
\hline Burner Operating Condition & High & Low \\
\hline Fuel Type & Diesel & Diesel \\
\hline \multicolumn{3}{|c|}{ Gas Emissions as Measured (dry basis): } \\
\hline CO - startup peak, $\quad$ ppm & NA & NA \\
\hline CO - steady state, & 25 & 10 \\
\hline CO - shutdown peak, & 25 & 10 \\
\hline NOx & 27 & 21 \\
\hline$\% 02$ & 18.7 & 19.2 \\
\hline \multicolumn{3}{|l|}{ Emissions corrected to $3 \% \mathrm{O2}$} \\
\hline CO - startup, $\quad$ ppm & NA & NA \\
\hline CO - steady state, & 196 & 100 \\
\hline CO - shutdown peak, & 196 & 100 \\
\hline $\begin{array}{ll}\text { NOx } & \mathrm{ppm} \\
\end{array}$ & 211 & 210 \\
\hline
\end{tabular}

Table 2. M-3 Burner - Carbon Monoxide, Nitrogen Oxides and Oxygen Content

\begin{tabular}{|c|c|c|}
\hline Burner Type & M3 & M3 \\
\hline Burner Operating Condition & High & Low \\
\hline Fuel Type & Diesel & Diesel \\
\hline \multicolumn{3}{|l|}{ Particulate Measurements } \\
\hline $\begin{array}{l}\text { Concentration of particulates in stack gas, } \\
\text { dry basis, mg/dscf }\end{array}$ & 0.117 & 0.112 \\
\hline Total particulates emitted, $\mathrm{lb} / 100 \mathrm{lb}$ fuel & 0.035 & 0.037 \\
\hline Total particulates emitted, $\mathrm{mg} / \mathrm{hr}$ & 487 & 249 \\
\hline Total particulates emitted, $\quad \mathrm{lb} / \mathrm{MBR}$ & 0.018 & 0.019 \\
\hline
\end{tabular}

\section{Table 3. M-3 Burners - Particulate Emissions}

A summary of the formaldehyde measurements is shown in Table 4 with values on an "as measured basis" which are the average stack concentrations, and with values that were corrected to $3 \% \mathrm{O} 2$. Using these concentrations as guidelines the measured stack emissions currently meet the permissible exposure limit of $0.75 \mathrm{ppm}$ although ambient exposure monitoring according to OSHA requirements would be needed to determine true values. 


\begin{tabular}{|c|c|c|}
\hline Burner Type & M3 & M3 \\
\hline Burner Operating Condition & High & Low \\
\hline Fuel Type & Diesel & Diesel \\
\hline \multicolumn{3}{|l|}{ Formaldehyde Measurements } \\
\hline $\begin{array}{l}\text { Measured concentration of formaldehyde } \\
\text { in stack, ppm }\end{array}$ & 0.370 & 0.084 \\
\hline \begin{tabular}{|l|} 
Concentration of formaldehyde \\
corrected to $3 \% \mathrm{O} 2, \quad \mathrm{ppm}$
\end{tabular} & 2.90 & 0.84 \\
\hline
\end{tabular}

Table 4. M-3 Burners - Formaldehyde Emissions

\subsection{GENERAL COMMENTS AND OBSERVATIONS}

The M-3 multifuel burner was substituted for the Karcher burner by the Natick RD\&E technical representative when Karcher failed to send a unit for testing at BNL.

The M-3 unit design was constrained by the major requirement that it be self-powered. It does not require any electrical power to operate. It depends on compressed air in the fuel tank to power the atomization process during start-up and pre-vaporization of the fuel during its steady burn operation.

The unit tested by BNL functioned as expected during its initial tests. The unit must be started outdoor, as it takes thirty minutes or more to reach steady burning conditions and to eliminate the excess raw fuel that is captured in a lower reservoir during the start-up phase of operation. The initial start-up phase also produces large amounts of heavy (very visible levels) smoke which would be totally unacceptable if it occurred indoors. The nozzle on the main burner of this unit would coke up due to carbon fouling and require cleaning prior to each test run. Upon reaching a steady burning condition, with only the main burner operating, the flame was stable and blue in color with yellow tips. This is typical of a natural gas burner and a good indictor that the burner was properly pre-vaporizing the fuel prior to combustion.

The unit was tested with Diesel fuel and the emission results have been documented earlier. During the last of these tests, the unit developed a fuel leak in the fuel vaporization tube and the leak produced a small flame (similar to a pilot light on a gas stove). Upon consulting with the Natick technical representative, BNL was informed that this had been observed before and was most likely related to corrosion of the component in question. BNL was notified that the problem would only get worse. Pre-vaporized diesel or JP-8 fuel will act much like natural gas or propane and must be handled as such. They no longer have the safe characteristics associated with the liquid fuel state. The unit was determined to be unsafe for continued use and Natick recommended that we discontinued any further tests. As a result of this recommendation, the tests of M-3 unit were stopped and the planned remaining tests (firing JP-8 fuel) were not conducted. 


\subsection{REFERENCES}

[1] EPA Code of Federal Regulations, 40 CFR Part 60, Appendix A, Method 5, 1990.

[2] National Institute for Occupational Safety and Health, NIOSH Manual of Analytical Methods, Third edition, 1989. 


\subsection{APPENDIX}

\section{A. FUELS ANALYSES}

This section contains the analyses for the test fuel D-2 Diesel.

\section{B. DATA TABLES}

This section contains information on the operating parameters recorded during each set of tests, fuel composition, measured and calculated data to determine emission factors. Results have been provided for diesel fuel. 


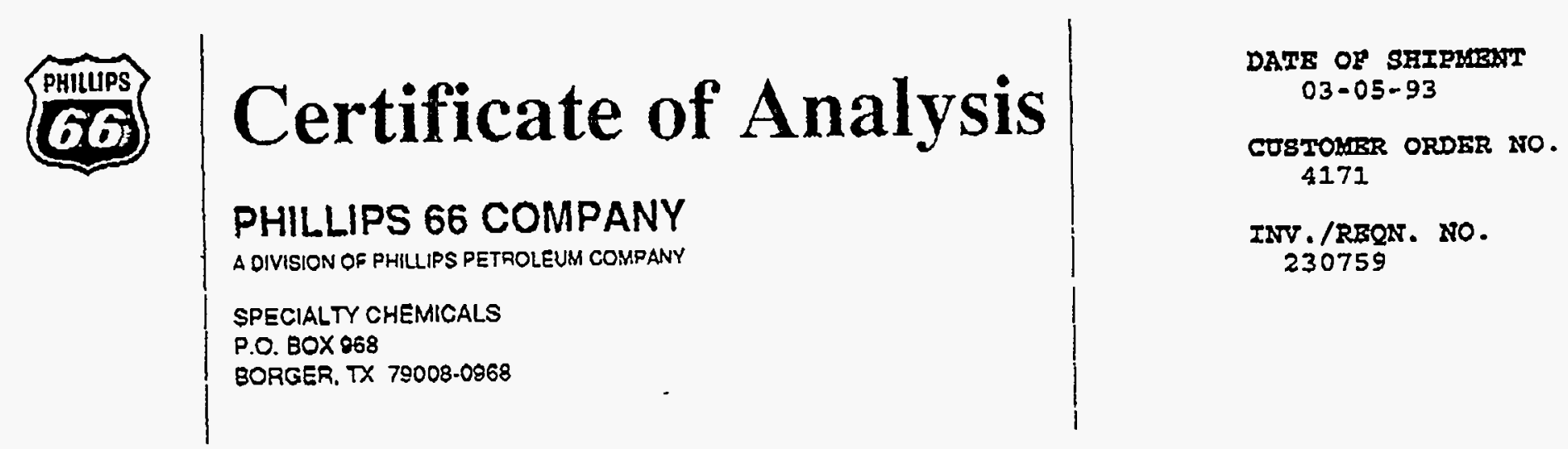

EORD CUSTOS D-2 DIESEI RUEL IOT $R-287$

Tㅍㅗㅗ

API Gravity

Sulfux

Flash Point, $P M$, ${ }^{\circ}$

Viscosity, cs $40 \mathrm{C}$

Particulate Matter (mg/l)

pour point

cloua point

DISTTITATION, D-86, ${ }^{\circ} \mathrm{F}$

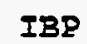

$5 \%$

$10 \%$

$25 \%$

$20 \%$

$30 \%$

408

$50 \%$

$60 \%$

708

807

$90 \frac{2}{8}$

$95 \%$

59

LOSB

Residue

EYPROCARBOA TYPE, VOLF

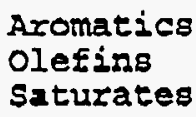

Cetane Index

cetane Number

GPA: BE : jam

05/09/1994
RESOLTS

$$
\begin{gathered}
35.4 \\
0.2069 \\
147 \\
2.5 \\
0.4 \\
\\
\end{gathered}
$$

\section{SEECIFICATIONS}

$33-37$

$0.20-0.50$

$130 \mathrm{Miz}$.

$2.0-3.2$

15 Max.

Report

Report

$340-400$

$400-460$

$470-540$

$550-620$

$580-660$

0.0

1.6

34.9

1.7

$\frac{63.4}{100.0}$

$27-35$

47

43-47

45

$42-50$ 


\begin{tabular}{|c|c|c|c|}
\hline & $\mathbf{F}$ & G & $\mathbf{H}$ \\
\hline 1 & \multirow{2}{*}{\multicolumn{3}{|c|}{$\begin{array}{l}\text { TESTING OF PROTOTYPE BURNERS - WORK CONDUCTED FOR U.S. ARMY, NATICK R\&D CTR } \\
\text { THIS DATABASE (SETUP ONEXCEL 4.0) PROVIDES THE RAW DATA AND CALCULATIONS }\end{array}$}} \\
\hline 2 & & & \\
\hline$\overline{3}$ & \multicolumn{3}{|c|}{ NEEDED TO DETERMINE STOVE EMISSIONS WTTH DIFFERENT FUEL TYPES } \\
\hline 4 & \begin{tabular}{|l|} 
Prepared by Wai-Lin Litzke and Yusuf Celebi \\
\end{tabular} & & \\
\hline \multicolumn{4}{|c|}{$x_{1}$} \\
\hline 6 & Burner Type & M3 & M3 \\
\hline 7 & Burner Operating Condition & High & Low \\
\hline 8 & Fuel Type & Diesel & Diesel \\
\hline \multicolumn{4}{|l|}{9} \\
\hline 10 & Fuel Composition (\% by wt) & & \\
\hline 11 & $\% \mathrm{C}$ & 87.3 & 87.3 \\
\hline 12 & $\% \mathrm{H}$ & 12.5 & 12.5 \\
\hline 13 & $\% \mathrm{~S}$ & 0.21 & 0.21 \\
\hline \multicolumn{4}{|c|}{14} \\
\hline \multicolumn{4}{|c|}{15 Operating Conditions } \\
\hline 16 & Stack draft, & 0.055 & \\
\hline 17 & Stack Temp. , & 512 & 392 \\
\hline 18 & Stack Temp, K $\quad$ (Ts) & 540 & 473 \\
\hline 19 & $\% 02$ measured, dry basis & 18.7 & 19.2 \\
\hline 20 & beta term & 10.41 & 10.41 \\
\hline 21 & alpha & 7.59 & 9.95 \\
\hline 22 & $\%$ Excess Air & 759 & 995 \\
\hline 23 & $(1+$ alpha $)$ & 8.59 & 10.95 \\
\hline 24 & kg water $/ \mathrm{kg}$ dry air $=\mathrm{W}$ (ie. ambient $=.01$ ) & 0.01 & 0.01 \\
\hline \multicolumn{4}{|c|}{25} \\
\hline 26 & Products of Combustion & & \\
\hline 27 & $\mathrm{CO} 2$, moles & 7.28 & 7.28 \\
\hline 28 & $\mathrm{~N} 2$, moles & 336.11 & 428.35 \\
\hline 29 & 02, moles & 78.98 & 103.52 \\
\hline 30 & SO2, moles & 0.007 & 0.007 \\
\hline 31 & Water, moles & 13.05 & 14.92 \\
\hline 32 & $\mathrm{Kg}$ dry gas/ $100 \mathrm{Kg}$ fuel $(\mathrm{CO} 2, \mathrm{~N} 2, \mathrm{O} 2, \mathrm{SO} 2)$ & 12259 & 15627 \\
\hline 33 & $\mathrm{Kg}$ water/100 Kg fuel & 235 & 269 \\
\hline 34 & Moisture Content & 0.030 & 0.027 \\
\hline$\overline{35}$ & Mol. Wt. of dry gas, $\mathrm{gm} / \mathrm{mol}$ & 29.024 & 28.984 \\
\hline 36 & Density of dry gas, gm/liter at stack temp & 0.656 & 0.747 \\
\hline 37 & $\mathrm{lb} / \mathrm{ft} 3$ & 0.041 & 0.047 \\
\hline 38 & lib dry gas/lb fuel & 122.59 & 156.27 \\
\hline 39 & Fuel flowrate, & 0.44 & 0.21 \\
\hline 40 & Fuel flowrate, & 3.11 & 1.48 \\
\hline 41 & lo dry gas/min & 6.35 & 3.86 \\
\hline 42 & dry gas acfm & 155.13 & 82.75 \\
\hline 43 & Stack gas flowrate, & 4179 & 2229 \\
\hline 44 & & & \\
\hline 45 & & & \\
\hline 46 & & & \\
\hline 47 & & & \\
\hline 48 & & & \\
\hline 49 & & & \\
\hline
\end{tabular}


DATA FOR THE M-3 UNIT - DIESEL FUEL

\begin{tabular}{|c|c|c|c|}
\hline & $F$ & $\mathbf{G}$ & $\mathrm{H}$ \\
\hline 50 & Gas Emissions as Measured (dry basis): & & \\
\hline 51 & CO - startup peak, $\quad$ ppm & NA & $\mathrm{NA}$ \\
\hline 52 & CO - steady state, & 25 & 10 \\
\hline 53 & CO - shutdown peak, & 25 & 10 \\
\hline 54 & NOx & 27 & 21 \\
\hline 55 & $\% \mathrm{O} 2$ & 18.7 & 19.2 \\
\hline 56 & & & \\
\hline 57 & Particulate Measurements & & \\
\hline 58 & Total amount collected, & 0.0073 & 0.0071 \\
\hline 59 & Temp. at meter, $\quad F$ & 71.6 & 76.6 \\
\hline 60 & Dry gas volume sampled, $\quad$ dcf & 63.067 & 64.55 \\
\hline 61 & Dry gas volume sampled, std. cond., dscf & 62.640 & 63.515 \\
\hline 62 & $\begin{array}{l}\text { Concentration of particulates in stack gas, dry basis, } \\
\mathrm{mg} / \text { dscf }\end{array}$ & 0.117 & 0.112 \\
\hline 63 & & & \\
\hline 64 & Formaldehyde Measurements & & \\
\hline 65 & Total mass collected, ug & 42.2 & 10 \\
\hline 66 & Volume sampled, (std. liters) & 92.9 & 97 \\
\hline 67 & Concentration in vol. sampled, $\mathrm{mg} / \mathrm{scm}$ & 0.454 & 0.103 \\
\hline 68 & $\mathrm{mg} / \mathrm{scf}$ & 0.013 & 0.003 \\
\hline 69 & Total formaldehyde emitted, $\quad \mathrm{lb} / \mathrm{lb}$ fuel & $3.8091 \mathrm{E}-05$ & $9.67178 \mathrm{E}-06$ \\
\hline 70 & Concentration of formald. in stack, $\mathrm{ppm}$ & 0.370 & 0.084 \\
\hline 71 & & & \\
\hline
\end{tabular}




\section{PERFORMANCE TEST REPORT - EXHAUST EMISSIONS \\ FOR THE ITR MULTIFUEL BURNER}

W. Litzke, Y. Celebi, and R. Mc Donald

August 1994

Energy Efficiency \& Conservation Division

Department of Applied Science

Brookhaven National Laboratory

Upton, New York 11973

This work was performed under the auspices of the U.S. Department of Energy Washington, D.C. Under Contract No. DE-AC02-76CH00016 


\section{$\cdot$}




\section{TABLE OF CONTENTS}

SECTION

PAGE

1.0

INTRODUCTION $\ldots \ldots \ldots \ldots \ldots \ldots \ldots \ldots \ldots \ldots \ldots$

1.1 Objective $\ldots \ldots \ldots \ldots \ldots \ldots \ldots \ldots \ldots \ldots \ldots \ldots \ldots \ldots \ldots$

1.2 Background $\ldots \ldots \ldots \ldots \ldots \ldots \ldots \ldots \ldots \ldots \ldots \ldots$

1.3 Technical Approach $\ldots \ldots \ldots \ldots \ldots \ldots \ldots \ldots \ldots$

2.0 MEASUREMENT TECHNIQUE AND INSTRUMENTATION .... 2

2.1 Description of Burner and Test Operating Conditions .... 2

2.2 Experimental Arrangement . . . . . . . . . . 5

2.3 Flue Gas Analyses $\ldots \ldots \ldots \ldots \ldots \ldots \ldots \ldots \ldots$

2.4 Particulate Emissions $\ldots \ldots \ldots \ldots \ldots \ldots \ldots \ldots \ldots$

2.5 Formaldehyde $\ldots \ldots \ldots \ldots \ldots \ldots \ldots \ldots \ldots \ldots$

2.6 Transient Smoke $\ldots \ldots \ldots \ldots \ldots \ldots \ldots \ldots \ldots \ldots \ldots$

$3.0 \quad$ EXPERIMENTAL RESULTS $\ldots \ldots \ldots \ldots \ldots \ldots \ldots \ldots$

3.1 Emissions Measurements $\ldots \ldots \ldots \ldots \ldots \ldots \ldots$

3.2 Cold Soak Test $\ldots \ldots \ldots \ldots \ldots \ldots \ldots \ldots \ldots \ldots$

4.0 GENERAL COMMENTS AND OBSERVATIONS $\ldots \ldots \ldots \ldots 12$

$5.0 \quad$ REFERENCES $\ldots \ldots \ldots \ldots \ldots \ldots \ldots \ldots \ldots \ldots \ldots \ldots \ldots \ldots \ldots$

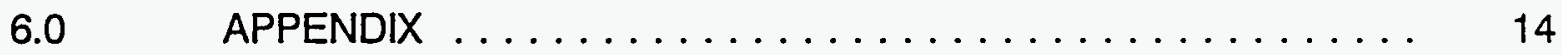

A. Fuels Analyses $\ldots \ldots \ldots \ldots \ldots \ldots \ldots \ldots \ldots \ldots \ldots \ldots$

B. Data Tables ...................... 14 


\section{LIST OF FIGURES}

FIGURES

PAGE

1

Schematic for Test Sampling System . . . . . . . . . . 3

2 Particulate Emissions Sampling System . . . . . . . . . 6

3

Fórmaldehyde Sampling Train $\ldots \ldots \ldots \ldots \ldots \ldots \ldots$

4

ITR Burner - Transient Smoke Numbers during Startup $\ldots . .9$ 


\section{LIST OF TABLES}

TABLES

PAGE

$1 \quad$ ITR Test Conditions $\ldots \ldots \ldots \ldots \ldots \ldots \ldots \ldots \ldots \ldots \ldots$

2 ITR Burner-Carbon Monoxide, Nitrogen Oxides and Oxygen Content ...................... 8

$3 \quad$ ITR Burner - Particulate Emissions $\ldots \ldots \ldots \ldots \ldots \ldots \ldots$

$4 \quad$ ITR Burner - Formaldehyde Emissions $\ldots \ldots \ldots \ldots \ldots \ldots \ldots$

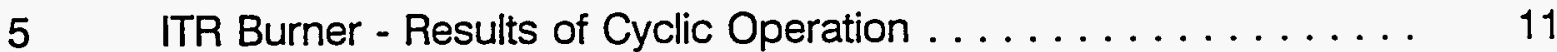




\subsection{INTRODUCTION}

\subsection{Objective}

The objective of this project is to provide data to the U.S. Army Natick RD\&E Center on the performance of three prototype burners, which have the capability of firing with multiple types of fuels (diesel and JP-8), and the conventional gasoline-fired M-2 burner. The prototype burners are intended to replace the M-2 unit currently used in food cooking appliances in the Army. The burners supplied to Brookhaven National Laboratory (BNL) for the purpose of testing under this project included one M-2 unit, one M-3 prototype unit designed by Natick, one Babington prototype unit designed by Babington Engineering, and one ITR prototype designed by International Thermal Research Ltd. It should be noted, however, that after the project began Babington Engineering provided an upgraded prototype unit for testing which replaced the unit initially provided by the Natick Center. The M-3 unit replaced the Karcher unit listed in the contract. These arrangements were agreed upon by the Army Project Officer and BNL at the outset of the experimental work.

The test procedures which were described in a Test Method Report allowed for the measurement of the concentrations of specific compounds emitted from the burners. These compounds included oxygen $\left(\mathrm{O}_{2}\right)$, carbon monoxide $(\mathrm{CO})$, oxides of nitrogen (NOx), formaldehyde, and particulate emissions. The level of smoke produced was also measured by using a Bacharach Smoke Number system (ASTM Standard D2156).

A performance test report has been prepared for each prototype burner that includes a description of the technology tested, a presentation of the results, and a discussion of practical observations about its operation and recommendations for improvements. This report details the results of the ITR burner only. A comparison of results for all burners will be summarized in a separate report entitled, Comparison of Emissions Characteristics of Prototype Advanced Burners.

- Babington Engineering provided an upgraded prototype unit for testing which replaced the unit initially provided by the Natick Center. This was agreed upon by the Army Project Officer and BNL at the outset of the project.

\subsection{Background}

The U.S. Army is currently interested in the development of advanced cooking appliances which can be fueled with distillate oil (diesel and JP-8) and deployed in the field. These appliance will be used in semi-enclosed areas and so it is important that the combustion process be consistently clean. Pollutants of potential concern include carbon monoxide, aldehydes, and particulates.

Federal agencies such as the Occupational Safety and Health Administration (OSHA) establish standards for permissible exposure limits to ensure that employees are not exposed to airborne concentrations of specific contaminants that exceed these limits. The current 
accepted exposure limit over an 8-hour period for $\mathrm{CO}$ is $35 \mathrm{ppm}$. The term "aldehydes" refers to a family of compounds with different levels of toxicity and concentration in combustion product exhaust. The dominant aldehyde in both exhaust products and the atmosphere is formaldehyde which has an 8-hour average exposure limit of $1 \mathrm{ppm}$. In automotive engine exhaust the total hydrocarbon emissions can be in the 100's of ppm range and aldehydes may be about $1 / 3$ of the total. Nitrogen oxides (NOx) generated from fuel oil combustion consist mostly of nitric oxide (NO) and nitrogen dioxide $\left(\mathrm{NO}_{2}\right)$ which have an 8-hour average exposure limit of $25 \mathrm{ppm}$ and a maximum limit of $5 \mathrm{ppm}$, respectively.

\subsection{Technical Approach}

In this project BNL has performed evaluation tests on prototype burners in support of the Army's efforts to develop advanced field cooking equipment. The basic test arrangement that was used is illustrated in Figure 1. All combustion products from the cooking appliance or prototype burner were collected in a hood and dilution tunnel arrangement. The flow in the dilution tunnel includes both combustion products and room air. The concentration of all pollutants was measured directly in the tunnel and, using fuel analyses information, the amount emitted was be related to the mass of fuel used. The burner fuel flow rate was measured and pollutant emissions are reported on: as measured, corrected to fixed excess air, mass/hour, mass per mass of fuel, and mass per unit of fuel heating value basis.

Testing during steady state operation consisted of turning the unit on, allowing it to run for the duration of the sampling time and then turning the unit off. For units that required a significant warmup period and did not readily ignite, such as the M2 and M3 units, steady state operation consisted of only the duration when the unit was firing stably. The long outdoor start-up period precludes any detailed transient measurements. For the ITR and Babington units, the start-up and shutdown emissions (transients) were also characterized. Clean transient operation is likely to lead to lower maintenance needs in the long term.

The fuels used in these tests consist of diesel (grade D-2), a kerosine type jet fuel (grade JP-8), and automotive gasoline. D-2 diesel has been specifically formulated for testing of equipment and is commonly used as a standard for testing mobile engines; JP-8 meets military specification MIL-T-83133. An analysis for each of these fuels was provided by Phillips 66 Company and they are included in the appendix of this report. The gasoline used for the M-2 burner was an unleaded regular grade of fuel.

\subsection{MEASUREMENT TECHNIQUE AND INSTRUMENTATION}

\subsection{Description of Burner and Test Operating Conditions}

The ITR unit consists of a dual set of burners with independent power switches. It consists of three major operating components, a fuel pump which supplies the fuel to both burners simultaneously, and two air compressors and igniters (one for each burner). 


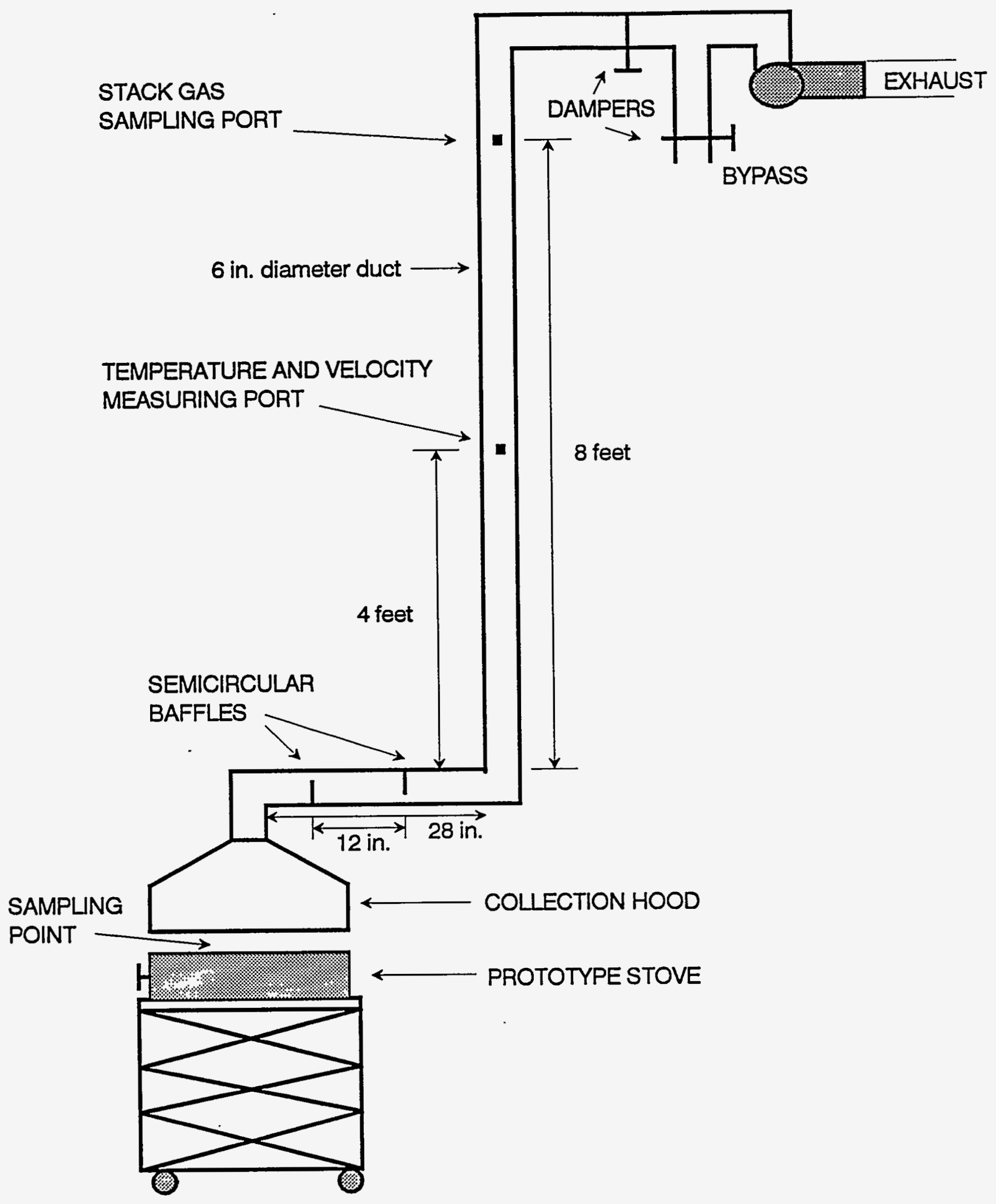

Figure 1. Schematic of Test Sampling System 
A 12-volt battery supplies the power to the unit. Upon start-up both the pump and the ignitors are activated and after about a 10-second delay the air compressors turn on. The air provided is necessary to draw the fuel through the air siphon nozzles. A flame detection rod is located directly above each flame zone to ensure adequate start-up. If the flame rod does not sense the flame within a short period of time after ignition the air compressor automatically shuts off so that additional fuel does not get delivered to the nozzle, and it will not restart until the unit is manually turned off and then turned on again to reinitiate a new start-up sequence.

A matrix of tests was conducted to evaluate overall performance of the prototype burner, emissions characteristics, and general ease of operation with respect to changes in fuel type, firing rate, ambient temperature, and mode of operation. Table 1 summarizes the operating conditions of each test.

Where both burners are used for a particular test, the firing rate shown is the combined rate for both burners for the duration of each test. A test indicated by LOW/HIGH means that the left burner (while facing the front control panel) was on LOW and the right burner on HIGH; a label - $\mathrm{LOW}$ means that only the right burner was used and was fired at a low rate. It should be noted however that in order to assure adequate startup the burner(s) must initially be turned on to its maximum firing rate and then reduced to the desired rate once the flame stabilizes. The entire range of firing rate was determined to be 22,500 to $62,300 \mathrm{Btu} / \mathrm{hr}$.

"Steady State" means that the test sequence consists of a startup, a continuous run for the duration of the sampling time of 100 minutes, and then shutdown. This total sampling time allows for an adequate amount of particulate matter and formaldehyde to be collected in the sampling trains as well as allow observations to be made of the burner performance over this period. The particulate and formaldehyde concentrations determined, therefore, represent time-averaged values for this entire test. "Transient" tests consist of a succession of startups and shutdowns of the unit over several cycles to obtain the average particulate concentrations over these transient periods. While it is not expected that total emissions from cyclic operation will be very important for the Army's application it may be helpful to identify designs which have particularly difficult starts and stops.

Almost all of the tests were performed under ambient temperatures of $68-75^{\circ} \mathrm{F}$ $\left(20-24^{\circ} \mathrm{C}\right)$. For the Babington and ITR burners a startup test after a cold soak was done. The cold soak test required that the stove be stored in an insulated cold-box filled with dry ice until the unit reached a temperature of about $-40^{\circ} \mathrm{F}\left(-40^{\circ} \mathrm{C}\right)$. A fan was installed to circulate the air within the box to ensure uniform temperatures. In addition, thermocouples were installed on several locations on the unit to monitor component temperatures. The stove was then brought out of the box after 6-8 hours of soaking and turned on immediately to determine operability of the unit. 


\begin{tabular}{|c|c|c|c|c|}
\hline Test & Fuel Type & $\begin{array}{c}\text { Firing Rate } \\
(\mathrm{Btu} / \mathrm{hr})\end{array}$ & $\begin{array}{c}\text { Firing } \\
\text { Rate } \\
(\mathrm{gph})\end{array}$ & $\begin{array}{c}\text { Operating } \\
\text { Mode }\end{array}$ \\
\hline HIGH/HIGH & Diesel & 58,600 & 0.44 & Steady State \\
\hline LOW/LOW & Diesel & 44,300 & 0.33 & Steady State \\
\hline - / LOW & Diesel & 22,500 & 0.17 & Steady State \\
\hline LOW/HIGH & Diesel & 54,600 & 0.41. & Steady State \\
\hline HIGH/HIGH & JP-8 & 62,300 & 0.47 & Steady State \\
\hline LOW/LOW & JP-8 & 44,950 & 0.34 & Steady State \\
\hline - / LOW & JP-8 & 23,000 & 0.18 & Steady State \\
\hline LOW/HIGH & JP-8 & 53,700 & 0.41 & Steady State \\
\hline Cyclic & Diesel & 58,600 & 0.44 & Transient \\
\hline Cyclic & JP-8 & 62,300 & 0.47 & Transient \\
\hline HIGH/HIGH & JP-8 & 62,300 & 0.47 & Cold Soak \\
\hline
\end{tabular}

Table 1. ITR Test Conditions

\subsection{Experimental Arrangement}

The dilution tunnel system collects all of the combustion products emitted from the burner into the hood where they are mixed with some room air which is also drawn in. By adjusting the dampers in the bypass system the induced draft could be adjusted such that the amount of dilution with room air was minimized. Thermocouples were set up along the 6 in. diameter duct at the sampling ports to measure stack gas temperatures. The centerline flue gas velocity was measured with a pitot tube upstream of the stack gas sampling port.

\subsection{Flue Gas Analyses}

In the dilution tunnel oxygen content $(\mathrm{O} 2)$ of the flue gas, carbon monoxide $(\mathrm{CO})$ and oxides of nitrogen (NOx) were measured in real-time during each test. The oxygen content which was measured with a paramagnetic analyzer (Beckman Model 755) was used to determine the excess air level. Carbon monoxide was measured with an infrared analyzer (Rosemount Analytical Model 880 ). $\mathrm{NO}_{\mathrm{X}}$ was measured with a chemiluminescent analyzer (Beckman Model 955). A value reported for the CO during startup or shutdown represents 
the peak value observed during the transient period; the steady state value represents the average number during the firing period. NOx generally increases during startup, reaches a steady level, and then decreases at shutdown; the values reported represent the average steady state concentrations. $\mathrm{CO}$ and NOx concentrations are presented in parts per million (ppm) and $\mathrm{O} 2$ in \% by volume of stack gas. By convention and for comparison emissions from stationary combustion choices are generally corrected for the differences in excess air and are represented at fixed $3 \% \mathrm{O} 2$.

A different approach was used to determine particulate and aldehyde emissions which provided a good measurement for these contaminants at low concentrations. The methods which will be described in further detail in the following sections require that integrated samples of flue gas be collected and then analyzed. In this manner, average emissions are determined for these contaminants over the entire test sequence.

\subsection{Particulate Emissions}

Particulate emissions are determined by the amount of material collected, by weight, on a glass fiber filter from the volume of tlue gas sampled. The flue gas was sampled directly from the dilution tunnel with a standard EPA Method 5 sampling train [1] . The sampling train, shown in Figure 2, consists of a stainless steel nozzle and filter holder with a preweighed glass fiber filter, a set of glass impingers kept at $32 \mathrm{~F}(0 \mathrm{C})$, a sampling pump, and a dry gas meter that measures the volume of dry gas sampled. The filter remains at the same temperature as the flue gas at the sampling point, which in these test cases is generally above the water or sulfuric acid dew point. The filter catch and materials washed from the nozzle probe were weighed to obtain the total particulates collected.

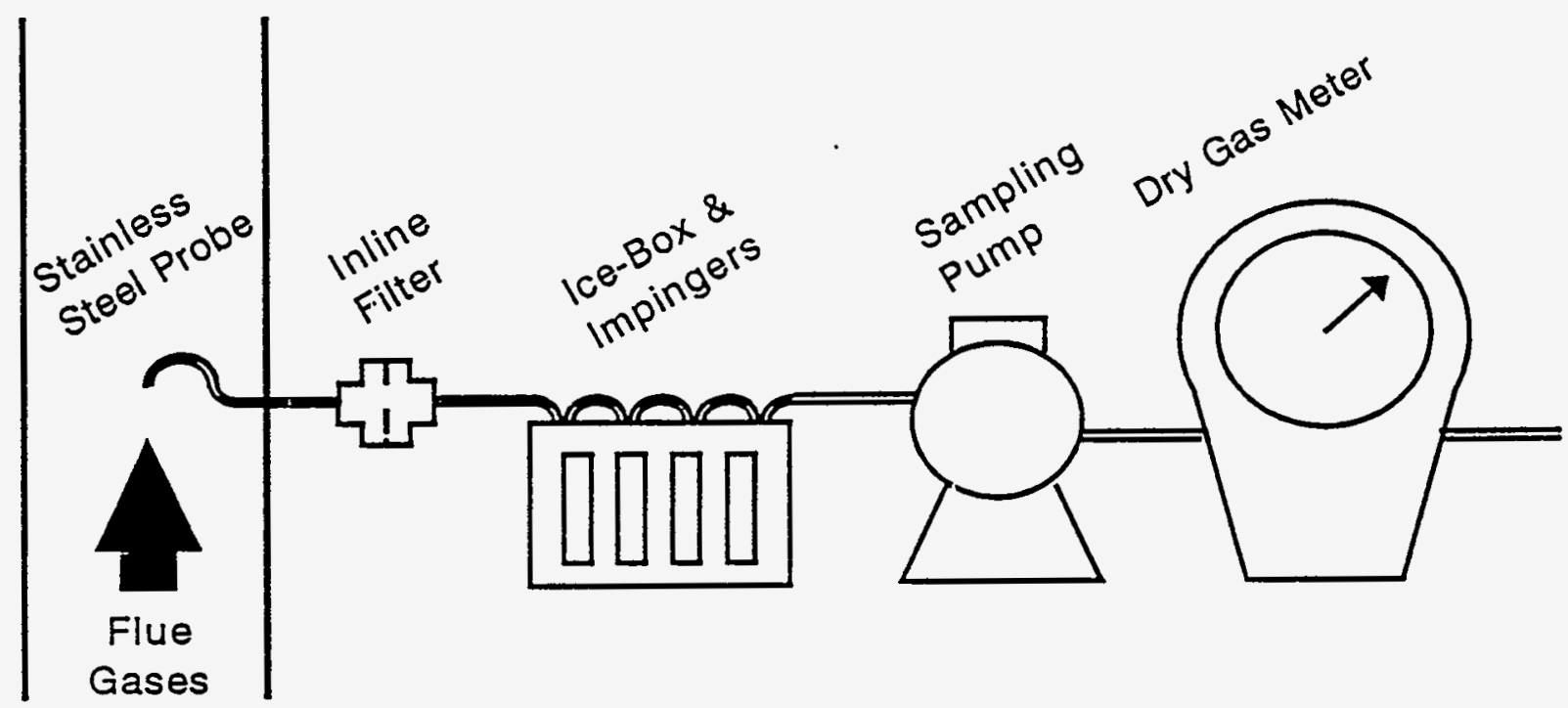

Figure 2. Particulate Emissions Sampling System 


\subsection{Formaldehyde}

A simple and quick, colorimetric method of analysis was used to determine formaldehyde concentrations which was derived from NIOSH Method 3500 [2]. This standard provides a monitoring method that applies to occupational exposure to airborne formaldehyde in the work area. It was used in these tests to draw samples directly from the dilution tunnel to obtain maximum possible contaminant levels in the stack gas. The sampling setup for these measurements is shown in Figure 3. Gas samples were bubbled through a set of glass impingers containing sodium bisulfite solution where formaldehyde is absorbed. A reaction of this solution with chromotropic acid and sulfuric acid yields a product that absorbs in the visible spectrum at $580 \mathrm{~nm}$ wavelength. Determination of formaldehyde concentrations is based on the absorbance measured.

Since this method is used to measure exposure levels at ambient temperatures a glass heat exchanger was added to the standard sampling train so that the sampled gas, which was typically above $300 \mathrm{~F}$, was allowed to cool to about $70 \mathrm{~F}$ before entering the sample impingers.

A maximum sample of $3.53 \mathrm{ft}^{3}$ (100 liters) collected gives a detection level as low as $0.02 \mathrm{ppm}$. A test run for 100 minutes at $1 \mathrm{liter} / \mathrm{min}$ sampling rate provides the time-weighted average concentration of formaldehyde for that period of time. Since most of the pollutants were emitted during the transient period (ie. startup), which usually lasts for about 1-2 minutes, the actual peak concentrations would be somewhat higher than the average value. An estimate of peak concentrations was obtained by cycling the burner such that enough gas is sampled during startups and shutdowns over successive cycles to do the analysis.

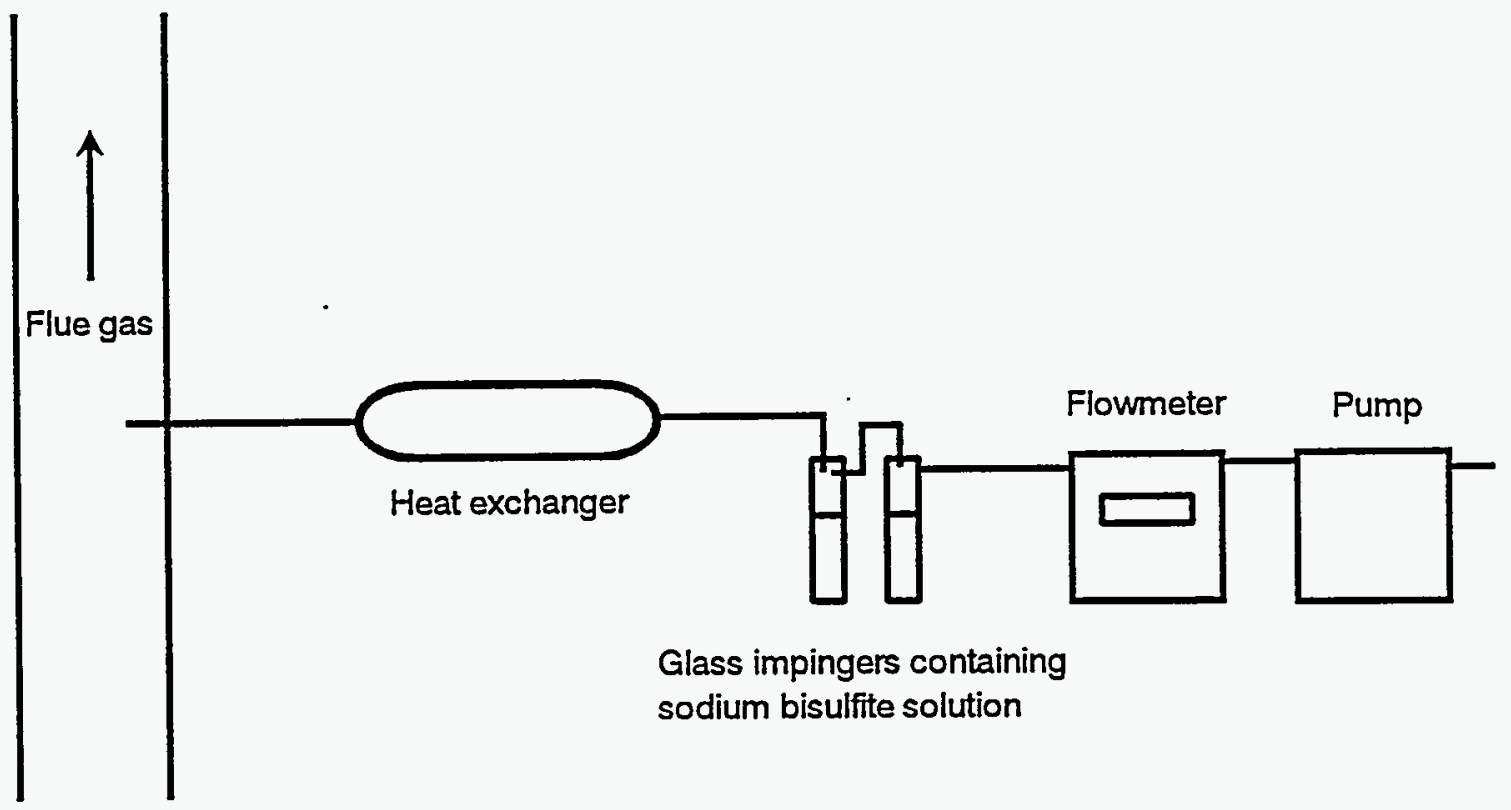

Figure 3. Formaldehyde Sampling Train 


\subsection{Transient Smoke}

Smoke is usually generated during the startup and/or shutdown periods of the firing cycle. The method used to determine smoke density is ASTM standard D2156 and has been expressed as the Bacharach Smoke Number. A standardized hand-pump was used to draw a fixed volume of flue gas through filter paper. The darkness of the spot is compared on a 0-9 scale on the smoke chart. During the startup transient multiple samples were taken to obtain a smoke number versus time curve. The amount of smoke dissipated after startup once the burner was firing steadily.

\subsection{EXPERIMENTAL RESULTS}

\subsection{Emissions Measurements}

Refer to Table 2 for some of the experimental results obtained for gaseous emissions during typical stove operation. Values for carbon monoxide (CO), oxides of nitrogen (NOx) and oxygen content $(\% \mathrm{O} 2)$ have been provided on an "as measured basis" which are direct readings of the flue gas measurements taken from the dilution tunnel, and emissions corrected to $3 \%$ oxygen content. The corrected values provide a common basis for comparison among different burners and different modes of operation. However, it could be reasonable to say that the "as measured" values are maximum possible concentrations observed when the stoves are used in an open system in which the ambient air provides the dilution. Carbon monoxide generated by the ITR during the startup period, which lasts about 1 minute, is high (above $5000 \mathrm{ppm}$ ). This is the maximum limit of the working range for the analytical instrument and is therefore reported as so. It should be noted, however, that the ITR unit initially started up at the maximum firing rate before reducing to the desired firing rate for the test once the flame stabilized. The $\mathrm{CO}$ decreased significantly once the steady state had been reached. In most cases, the $\mathrm{CO}$ increased again slightly during the shutdown period. The values reported for NOx are the average observed values during the steady firing period. The ITR operates effectively with both diesel and JP-8 and with no significant differences in these emissions once the steady state had been established.

The results of particulate emissions are shown in Table 3 and are given in several different units. The most common expressions are in the form of mass of pollutant/mass of fuel, or mass of pollutant/energy input. To convert from the measured stack gas concentration to these units the measured oxygen content of flue gas and assumed typical fuel analyses (for diesel and JP-8) were used to determine the excess air and the total flue gas flowrate. The results of all calculations are found in the appendix. The amount of particulates emitted reported are averaged values for the test sequence -startup, steady firing, and shutdown which totals to a sampling period of about 100 minutes. Most of the particulates were generated during startup and the following summary of the transient smoke measurements helps to support this observation. Particulate emissions ranged from 0.004 to $0.014 \mathrm{lb} /$ million Btu over the full firing range for both fuels, and on average is slightly higher for the diesel fuel than for JP-8. In 
addition it appears that the burner operates better at higher firing rates with slightly lower particulate values than at the lower firing rates.

\begin{tabular}{|c|c|c|c|c|c|c|c|c|}
\hline Burner Type & ITR & ITR & ITR & ITR & ITR & ITR & ITR & ITR \\
\hline Burner Operating Condition & High/High & Low/Low & $-/$ Low & Low/High & High/High & Low/Low & Low/High & - - Low \\
\hline Fuel Type & Diesel & Diesel & Diesel & Diesel & $\mathrm{JP}-8$ & JP-8 & $\mathrm{JP}-8$ & $\mathrm{JP}-8$ \\
\hline \multicolumn{9}{|c|}{ Gas Emissions as Measured (dry basis): } \\
\hline CO - startup peak, $\quad$ ppm & $>5000$ & $>5000$ & $>5000$ & $>5000$ & $>5000$ & $>5000$ & $>5000$ & 3900 \\
\hline CO - steady state, & 23 & 5 & 9 & 15 & 15 & 14 & 15 & 13 \\
\hline CO - shutdown peak, & 38 & 14 & 33 & 42 & 15 & 35 & 23 & 13 \\
\hline NOx & 24 & 16 & 10 & 27 & 36 & 15 & 25 & 6 \\
\hline$\% 02$ & 15.5 & 17.5 & 19.4 & 17.1 & 16.2 & 18.2 & 16.9 & 19.6 \\
\hline \multirow{2}{*}{\multicolumn{9}{|c|}{ Emissions corrected to $3 \% \mathrm{O} 2$}} \\
\hline & & & & & & & & \\
\hline CO - startup, & $>5000$ & $>5000$ & $>5000$ & $\geq 5000$ & $>5000$ & $>5000$ & $>5000$ & $>5000$ \\
\hline CO - steady state, & 75 & 26 & 101 & 69 & 56 & 90 & 66 & 167 \\
\hline CO - shutdown peak, & 124 & 72 & 371 & 194 & 56 & 225 & 101 & 167 \\
\hline NOx & 79 & 82 & 113 & 125 & 135 & 96 & 110 & 77 \\
\hline & & & & & & & & \\
\hline
\end{tabular}

Table 2. ITR Burner - Carbon Monoxide, Nitrogen Oxides and Oxygen Content

\begin{tabular}{|c|c|c|c|c|c|c|c|c|}
\hline Burner Type & ITR & ITR & ITR & ITR & ITR & ITR & ITR & ITR \\
\hline Burner Operating Condition & High/High & Low/Low & $-\pi$ Low & Low/High & High/High & Low/Low & Low/High & $-\pi$ Low \\
\hline Fuel Type & Diesel & Diesel & Diesel & Diesel & $\mathrm{JP}-8$ & JP-8 & JP-8 & JP-8 \\
\hline \multirow{2}{*}{\multicolumn{9}{|c|}{ Particulate Measurements }} \\
\hline Concentr. of particulates in & & & & & & & & \\
\hline stack gas, mg/dscf & 0.053 & 0.091 & 0.074 & 0.089 & 0.060 & 0.060 & 0.045 & 0.045 \\
\hline $\begin{array}{l}\text { Total particulates emitted; } \\
\mathrm{lb} / 100 \mathrm{lb} \text { fuel }\end{array}$ & 0.008 & 0.019 & 0.026 & 0.017 & 0.010 & 0.015 & 0.009 & 0.019 \\
\hline $\begin{array}{l}\text { Total particulates emitted, } \\
\mathrm{mg} / \mathrm{hr}\end{array}$ & 111 & 198 & 139 & 227 & 147 & 157 & 105 & 10 \\
\hline $\begin{array}{l}\text { Total particulates emitted, } \\
\text { lb/MBtu }\end{array}$ & 0.004 & 0.010 & 0.014 & 0.009 & 0.005 & 0.008 & 0.004 & 0.010 \\
\hline
\end{tabular}

Table 3. ITR Burner - Particulate Emissions 
Figure 4 shows the relationship of the smoke density (smoke number) with respect to time during startup. A comparison is made between fuel type, diesel and JP-8, for one and two burners operating (indicated by $-/ \mathrm{H}$ and $\mathrm{H} / \mathrm{H}$ respectively). For $\mathrm{JP}-8$ two duplicate test runs were made for both burners at high firing rate $(\mathrm{H} / \mathrm{H}-1$ and $\mathrm{H} / \mathrm{H}-2)$. Results show that the ITR starts up with higher smoke levels and has a longer transient period (up to 110 seconds after ignition) with diesel fuel than with the JP-8 fuel. Whether one or two burners are firing at the same time does not have as much effect on smoke number. This data supports the fact that most of the particulate emissions are generated during the transient period, and in this case during startup.

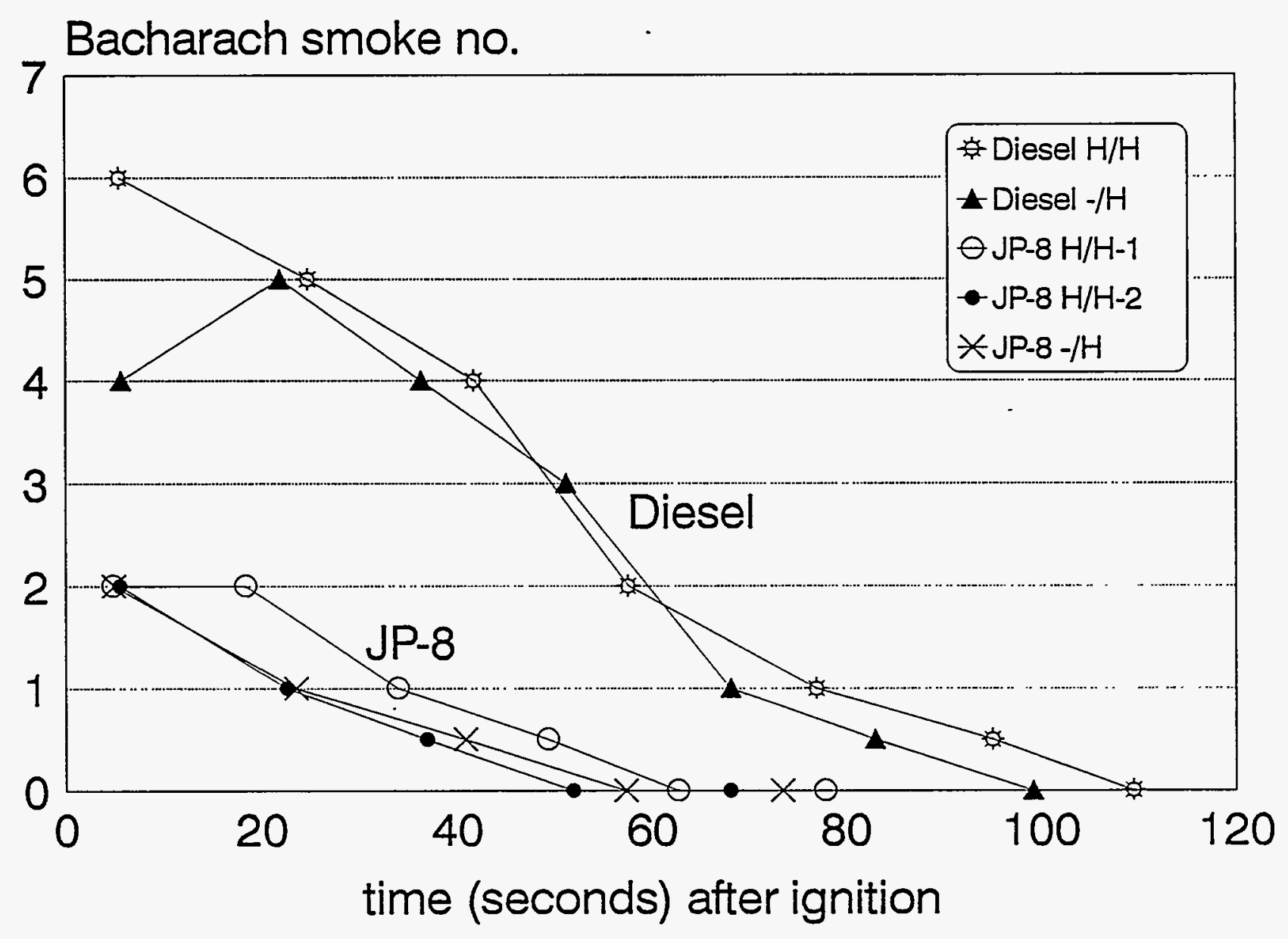

Figure 4. ITR Burner - Transient Smoke Numbers during Startup

A summary of the formaldehyde measurements is shown in Table 4 with values on an "as measured basis" which are the average stack concentrations, and with values that were corrected to $3 \% \mathrm{O} 2$. In general, these emissions are low when dilution with ambient air is considered, which may generally be the case under actual operating conditions in an open-fired system. Using these concentrations as guidelines they currently meet the permissible exposure limit of $0.75 \mathrm{ppm}$ although ambient exposure monitoring according to OSHA requirements would be needed to determine true values. 


\begin{tabular}{|l|l|l|l|l|l|l|l|l|}
\hline Burner Type & ITR & ITR & ITR & ITR & ITR & ITR & ITR & ITR \\
\hline Burner Operating Condition & High/High & Low/Low & \multicolumn{1}{l|}{ /Low } & Low/High & High/High & Low/Low & Low/High & - /Low \\
\hline Fuel Type & Diesel & Diesel & Diesel & Diesel & JP-8 & JP-8 & JP-8 & JP-8 \\
\hline & & & & & & & & \\
\hline Formaldehyde Measurements & & & & & & & & \\
\hline $\begin{array}{l}\text { Avg. concentration of } \\
\text { formaldehyde in stack, ppm }\end{array}$ & 0.31 & 0.30 & 0.17 & 0.21 & 0.36 & 0.31 & 0.21 & 0.23 \\
\hline $\begin{array}{l}\text { Avg. formaldehyde concentr. } \\
\text { corrected to 3\% O2, ppm }\end{array}$ & & & & & & & & \\
\hline
\end{tabular}

Table 4. ITR Burner - Formaldehyde Emissions

A set of data was taken in a "cyclic" mode of operation to generate several transient periods by turning the burner on and off successively during sampling for formaldehyde and particulates. This allows for an adequate amount of material to be collected for measurements and provides an estimate of the contribution of emissions from the transient periods. Startup periods are not necessarily the same during each cycle; for example, one of the two burners may ignite and stabilize more readily than the other. Although the prototype cookstoves have not been designed to operate in. such a fashion, a good estimate could be made of the average startup emissions. In addition, this data provides a relative comparison of the ease of startup for the different fuel types. For these tests with both diesel and JP-8, only the highest firing rate was considered and these results are tabulated as follows in Table 5.

\begin{tabular}{|c|c|c|}
\hline & Diesel & JP-8 \\
\hline Total particulates emitted, $\mathrm{lb} / 100 \mathrm{lb}$ fuel & 0.14 & 0.054 \\
\hline $\begin{array}{c}\text { Actual concentration of } \\
\text { formaldehyde } \\
\text { in stack, ppm }\end{array}$ & 8.84 & 6.78 \\
\hline
\end{tabular}

Table 5. ITR Burner - Results of Cyclic Operation

Startups seem to be less "clean" for the diesel fuel when compared with the JP-8 although the differences are not significant. It should be noted, however, that these startup emissions are much larger than the average emissions during typical operation of the stove where the burners are normally allowed to run in a steady state mode. 


\subsection{Cold Soak Test}

The cold soak test consisted of cooling the ITR unit in a cold-box containing dry ice for several hours to a temperature of $-40^{\circ} \mathrm{F}$. The unit was then brought out of the box and turned on in order to evaluate its operating characteristics. The temperature of several components were monitored as the tests continued. Initially the unit failed to start. Recognizing that the prototype unit had not been originally designed for the cold soak test, several attempts at firing the burner continued as the temperature quickly rose. The major components that did not operate at below- zero temperatures consisted of the fuel pump, air compressors, and ignitor. As the unit warmed up the pump and compressor began to operate and the fuel was spraying through the nozzle; however, ignition of the fuel did not occur until the surface temperature of the unit reached about $25^{\circ} \mathrm{F} \mathrm{F}$. Initial operation at this point was unsteady (flame sometimes goes out) and smokey. Uncombusted liquid fuel that was collected in the drip pan below the burner chamber ignited as it became hot when the burner was firing.

\subsection{GENERAL COMMENTS AND OBSERVATIONS}

The ITR unit is based on an air-siphon nozzle atomizer that has been used in other A.C. powered heating units, the most common being portable, unvented space heaters used on construction sites. The patented ITR combustion unit (as tested) is unique in that it does not use a combustion air blower depending solely on the compressed air used to atomize the fuel and atmospheric air induced into the burner for combustion air. To our knowledge, the ITR combustion design has not yet been introduced as a product in any end use market sector.

The ITR unit is powered by 12 D.C. (battery or power converter must be connected to a front panel socket) and switch operated for on-off control and uses two separate burners, each with a High/Low firing range, to achieve variable firing rates. Each burner is driven by a separate air compressor installed in the burner system. The individual burner High/Low fire control is achieved by bleeding some of the compressed air driving the air-siphon atomizer to effectively reduce the firing rate by reducing the air flow to the nozzle.

The unit operates in two distinct phases. During start-up, the unit burns rather poorly with very high smoke numbers and $\mathrm{CO}$ emissions (lasting up to one minute and 10 seconds) where the flame, orange-yellow in color, is internal to the burner air/fuel mixing tube. After transition to the second phase, the burner operates in a steady state where the unit acts to pre-vaporize the fuel which then burns with a blue flame which is established on a grid downstream of the internal mixing section where the yellow-orange flame is initially observed on start-up.

The unit is rather simple in design and affords accessibility as configured for maintenance and repair. However, the burner did not have an internal fuel tank or battery compartment as tested which would require considerable space if included in the design. Its controls were handwired, bread-board prototypes and will also require some development 
effort prior to production. The unit as currently designed would have to be started outdoors as it emits large amounts of $\mathrm{CO}(>5000 \mathrm{ppm})$ and some smoke prior to the steady burning blue flame condition. The unit also exhibited a combustion flare-up condition on start-up of the unit when one burner was already running properly and the second burner was then turned on. This occurred when the unit was first delivered during an outdoor cold weather demonstration by the Natick RD\&E representative when delivering the unit to BNL and several times during testing. The actual cause is unknown but may be related to fuel backing up into the compressed air line of the non-operational burner. This should not happen based on an inquiry with the manufacturer and may suggest that the fuel flow control device for the burner in question might have been defective.

The unit failed to start during the cold soak test $\left(-40^{\circ} \mathrm{F}\right)$ until some components warmed up to about $32^{\circ} \mathrm{F}$. One potential factor that could have significantly contributed to this is the ignition system which uses a glow plug (hot surface) type igniter. At low temperatures, this type of igniter is expected to be difficult to use. It must first warm itself up prior to attaining temperatures high enough to ignite a cold fuel (JP-8) air mixture. The electric current flowing through it provides this heat energy. It must first provide sufficient energy to heat the thermal mass (heat capacity) of the igniter and initial conductive heat losses to its mounting and convective heat losses to its surroundings.

\subsection{REFERENCES}

[1] EPA Code of Federal Regulations, 40 CFR Part 60, Appendix A, Method 5, 1990.

[2] National Institute for Occupational Safety and Health, NIOSH Manual of Analytical Methods, Third edition, 1989. 


\subsection{APPENDIX}

\section{A. FUELS ANALYSES}

This section contains the analyses for the test fuels D-2 Diesel and JP-8.

\section{B. DATA TABLES}

This section contains information on the operating parameters recorded during each set of tests, fuel composition, measured and calculated data to determine emission factors. Results have been provided for both diesel and JP-8 fuels. 


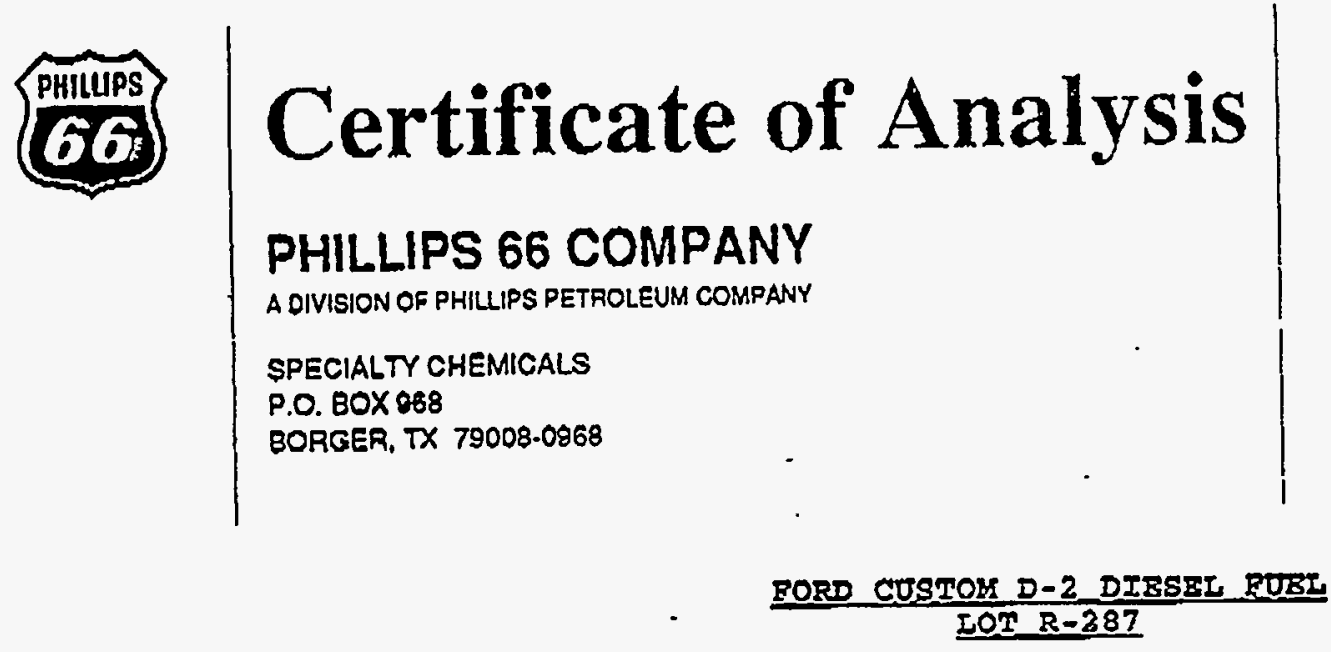

Ix+9

API Gxavity

SuIfux

Flash Point, PM, of

Viscosity, cs $40 \mathrm{C}$

Particulate Matter (mg/l)

pour Point

cloud Point

RTSTT TAFTOA, $R-86, \circ E$

IBP
54
108
258
208
308
408
508
$60 \%$
708
808
908
958
58
2088

Residue

TYDROCARBOA TYPE, VOL\%

\section{Aromatics \\ olefins \\ saturates}

Cetane Index

Cotgre Number

GRA : BE : jam

05/09/1994
DATE OP SFIPWHWT

$03-05-93$

COSTOLER ORDER NO. 4171

INV. /REON. NO. 230759

\section{SPECIFICATIONS}

33-37

$0.20-0.50$

130 Min.

2.0-3.2

15 Max.

Report

Report

$340-400$

$400-460$

$470-540$

$550-610$

$580-660$

0.0

1.5

$$
\begin{array}{r}
34.9 \\
7.7 \\
63.4 \\
\hline 100.0
\end{array}
$$

$27-35$

$43-47$

45 


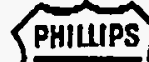 \\ Certificate of Analysis}

\section{PHILLIPS 66 COMPANY}

A DIVISION OF PHILLIPS PETROLEUM COMPANY

SPECIALTY CHEMICALS

P.O. BOX 968

BORGER, TX 79008-0958

\author{
DATE OF 8HIPAHNT \\ $04-06-94$ \\ CUSTOMER ORDER NO. \\ 728979 \\ INV. /RBQN. NO. \\ 441400 \\ $1 \times 54$ GAILON DROM
}

MII-T-83133C JP-8 IOT R-324

Tgsts

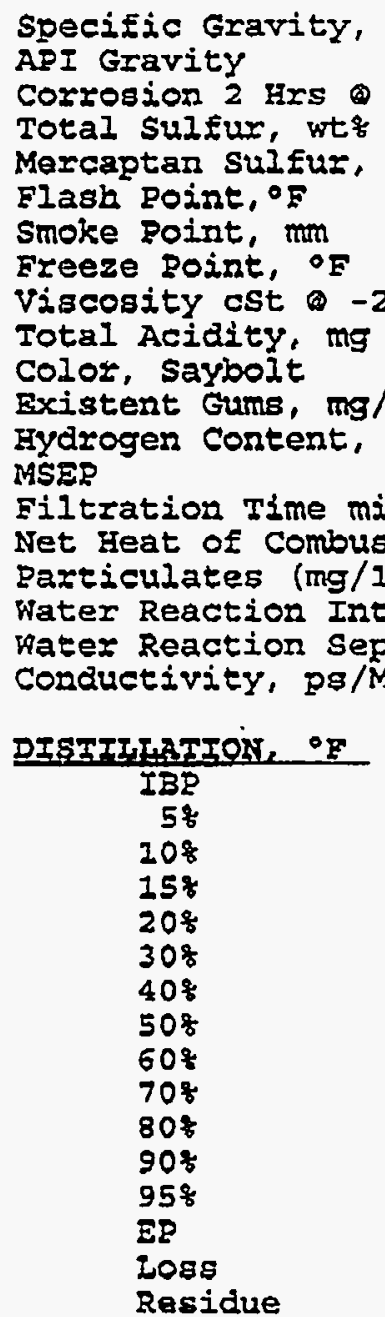

EYDROCARBON TYPE, VOI\%

Aromatics

Olexins

Saturates

JETOT^P (mutig)

JFror Tube Color Test

Anti-Icing (vol

Antioxidant (Ib/Mbbl)

Corrosion Inhibitor (Ib/Mobl)
RESULIS

\begin{tabular}{c}
0.7905 \\
47.5 \\
$1 a$ \\
0.0943 \\
.00032 \\
132 \\
25 \\
-60 \\
\multicolumn{1}{c}{5} \\
0.010 \\
$30+$ \\
0.31 \\
14.2 \\
87 \\
9 \\
18672 \\
0.24 \\
1 \\
0 \\
165
\end{tabular}

337

360

366

368

373

379

385

392

401

412

428

455

480

508

0.8

1.2

$572 \operatorname{Max}$

1. $5 \mathrm{Max}$

1.5 $\operatorname{Max}$
$0.775-0.8400$

$37.0-51.0$

1 Max

$0.30 \mathrm{Max}$

$0.002 \operatorname{Max}$

$200 \mathrm{Min}$

$25.0 \mathrm{Min}$

-53 Max

$8 \mathrm{Max}$

0.015 Max

Report

7.0 Max

$13.4 \mathrm{Min}$

$70 \mathrm{Min}$

$15 \mathrm{Max}$

18,400 $\mathrm{Min}$

1 Max

IB Max

2 Max

$150-600$

Report

401 Max
METHOD

ASTM D-4052

ASTM D-1298

ASTM D-130

ASTM D-2622

ASTM D-3227

ASTM D.93

ASTM D-1322

ASTM D-2386

ASTM D-445

ASTM D-3242

ASTM D- 156

ASTM D-381

ASTM D-370I

ASTM D-3948

ASTM D-3338

ASTM D-2276

ASTM D-1094

ASTM D-2550

ASTM D-2524

AS2M D-86

$\begin{array}{cl}14.0 & 25 \mathrm{Max} \\ 1.5 & 5 \mathrm{Max} \\ 84.5 & \\ 0 & 25 \mathrm{Max} \\ 1 & <3 \\ .10 & 0.10-0.15 \\ 6.5 & 6.0-8.4 \\ 5 & \text { Repoxt }\end{array}$

ASIM D-1319

ASTM D-3241

ASTM D-3241 


\begin{tabular}{|c|c|c|c|c|c|}
\hline & A & B & \begin{tabular}{|c|}
$\mathrm{C}$ \\
\end{tabular} & D & $\mathrm{E}$ \\
\hline 1 & \multirow{2}{*}{\multicolumn{5}{|c|}{$\begin{array}{l}\text { TESTING OF PROTOTYPE BURNERS - WORK CONDUCTED FOR U.S. ARMY, NATICK R\&D CTR } \\
\text { THIS DATABASE (SETUP ON EXCEL 4.0) PROVIDES THE RAW DATA AND CALCULATIONS } \\
\end{array}$}} \\
\hline 2 & & & & & \\
\hline 3 & \multicolumn{4}{|c|}{ NEEDED TO DETERMINE STOVE EMISSIONS WITH DIFFERENT FUEL TYPES } & \\
\hline 4 & Prepared by Wai-Lin Litzke and Yusuf Celebi & & & & \\
\hline 5 & & & & & \\
\hline 6 & Burner Type & ITR & ITR & ITR & ITR \\
\hline 7 & Burner Operating Condition & High/High & Low/Low & $-\pi$ Low & Low/High \\
\hline 8 & Fuel Type & Diesel & Diesel & Diesel & Diesel \\
\hline 9 & & & & & \\
\hline 10 & Fuel Composition (\% by wt) & & & & \\
\hline 11 & $\% \mathrm{C}$ & 873 & 87.3 & 87.3 & 87.3 \\
\hline 12 & $\% \mathrm{H}$ & 12.5 & 12.5 & 12.5 & 12.5 \\
\hline 13 & $\% \mathrm{~S}$ & 0.21 & 0.21 & 0.21 & 0.21 \\
\hline 14 & & & & & \\
\hline 15 & Operating Conditions & & & & \\
\hline 16 & $\begin{array}{ll}\text { Stack draft, } & \text { in. w.c. } \\
\end{array}$ & 0.065 & 0.06 & 0.05 & 0.062 \\
\hline 17 & $\begin{array}{ll}\text { Stack Temp. , } & \text { F } \\
\end{array}$ & 716 & 565 & 337 & 630 \\
\hline 18 & \begin{tabular}{|ll} 
Stack Temp, K & (Ts) \\
\end{tabular} & 653 & 569 & 442 & 605 \\
\hline 19 & $\% \mathrm{O} 2$ measured, dry basis & 15.5 & 17.5 & 19.4 & 17.1 \\
\hline 20 & beta term & 10.41 & 10.41 & 10.41 & 10.41 \\
\hline 21 & alpha & 2.64 & 4.67 & 11.30 & 4.10 \\
\hline 22 & $\%$ Excess Air & 264 & 467 & 1130 & 410 \\
\hline 23 & $(1+$ alpha) & 3.64 & 5.67 & 12.30 & 5.10 \\
\hline 24 & $\mathrm{~kg}$ water $/ \mathrm{kg}$ dry air $=\mathrm{W}$ (ie. ambient $=.01$ ) & 0.01 & 0.01 & 0.01 & 0.01 \\
\hline 25 & & & & & \\
\hline 26 & Products of Combustion & & & & \\
\hline 27 & \begin{tabular}{|l|}
$\mathrm{CO} 2$, moles \\
\end{tabular} & 7.28 & 7.28 & 7.28 & 7.28 \\
\hline 28 & $\mathrm{~N} 2$, moles & 142.29 & 221.99 & 481.31 & 199.52 \\
\hline 29 & O2, moles & 27.44 & 48.63 & 117.60 & 42.66 \\
\hline 30 & $\mathrm{SO} 2$, moles & 0.007 & 0.007 & 0.007 & 0.007 \\
\hline 31 & Water, moles & 9.130 & 10.743 & -15.991 & 10.288 \\
\hline 32 & $\mathrm{Kg}$ dry gas/ $100 \mathrm{Kg}$ fuel $(\mathrm{CO} 2, \mathrm{~N} 2, \mathrm{O} 2, \mathrm{SO} 2)$ & 5182 & 8092 & 17560 & 7272 \\
\hline 33 & $\mathrm{Kg}$ water $/ 100 \mathrm{Kg}$ fuel & 164 & 193 & 288 & 185 \\
\hline 34 & Moisture Content & 0.049 & 0.037 & 0.026 & 0.040 \\
\hline 35 & Mol. Wt. of dry gas, $\mathrm{gm} / \mathrm{mol}$ & 29.278 & 29.119 & 28.968 & 29.151 \\
\hline 36 & Density of dry gas gm/liter at stack temp & 0.547 & 0.624 & 0.798 & 0.587 \\
\hline 37 & $\mathrm{lb} / \mathrm{ft} 3$ & 0.034 & 0.039 & 0.050 & 0.037 \\
\hline 38 & $\mathrm{lb}$ dry gas/lb fuel & 51.82 & 80.92 & 175.60 & 72.72 \\
\hline 39 & Fuel flowrate, & 0.44 & 0.33 & 0.17 & 0.41 \\
\hline 40 & Fuel flowrate, & 3.09 & 2.33 & 1.19 & 2.87 \\
\hline 41 & Ib dry gas/min & 2.67 & 3.15 & 3.47 & 3.48 \\
\hline 42 & dry gas acfm & 78.11 & 80.74 & 69.62 & 94.94 \\
\hline 43 & Stack gas flowrate, & 2104 & 2175 & 1876 & 2558 \\
\hline 44 & & & & & \\
\hline 45 & & & & & \\
\hline 46 & & & & & \\
\hline 47 & & & & & \\
\hline 48 & & & & & \\
\hline 49 & & & & & \\
\hline
\end{tabular}


DATA FOR THE ITR UNIT - DIESEL FUEL

\begin{tabular}{|c|c|c|c|c|c|}
\hline & A & B & C & D & E \\
\hline 50 & Gas Emissions as Measured (dry basis): & & & & \\
\hline 51 & CO - startup peak, $\quad$ ppm & $>5000$ & $>5000$ & $>5000$ & $>5000$ \\
\hline 52 & CO - steady state, & 23 & 5 & 9 & 15 \\
\hline 53 & CO - shutdown peak, & 38 & 14 & 33 & 42 \\
\hline 54 & NOx & 24 & 16 & 10 & 27 \\
\hline 55 & $\% \mathrm{O} 2$ & 15.5 & 17.5 & 19.4 & 17.1 \\
\hline \multicolumn{6}{|c|}{$\begin{array}{ll}56 & \\
\end{array}$} \\
\hline 57 & Particulate Measurements & & & & \\
\hline 58 & Total amount collected, & 0.0034 & 0.0055 & 0.0044 & 0.0055 \\
\hline 59 & Temp. at meter, $\quad F$ & 73 & 72.6 & 73 & 80 \\
\hline 60 & Dry gas volume sampled, $\quad$ dcf & 64.8 & 61.07 & 60.11 & 63.432 \\
\hline 61 & \begin{tabular}{|l|} 
Dry gas volume sampled, std. cond., dscf \\
\end{tabular} & 64.192 & 60.543 & 59.546 & 62.022 \\
\hline 62 & $\begin{array}{l}\text { Concentration of particulates in stack gas, dry basis, } \\
\mathrm{mg} / \mathrm{dscf}\end{array}$ & 0.053 & 0.091 & 0.074 & 0.089 \\
\hline \multicolumn{6}{|c|}{\begin{tabular}{l|l}
63 & 2 \\
\end{tabular}} \\
\hline 64 & Formaldehyde Measurements & & & & \\
\hline 65 & Total mass collected, ug & 34.8 & 35 & 19.2 & 24.8 \\
\hline 66 & Volume sampled, (std. liters) & 92.4 & 95.6 & 91.2 & 95.4 \\
\hline 67 & Concentration in vol. sampled, $\mathrm{mg} / \mathrm{scm}$ & 0.377 & 0.366 & 0.211 & 0.260 \\
\hline 68 & $\mathrm{mg} / \mathrm{scf}$ & 0.011 & 0.010 & 0.006 & 0.007 \\
\hline 69 & Total formaldehyde emitted, $\quad \mathrm{lb} / \mathrm{lb}$ fuel & $1.6014 \mathrm{E}-05$ & $2.1301 \mathrm{E}-05$ & $2.0772 \mathrm{E}-05$ & $1.4439 \mathrm{E}-05$ \\
\hline 70 & Concentration of formald. in stack, $\mathrm{ppm}$ & 0.307 & 0.298 & 0.172 & 0.212 \\
\hline 71 & & & & & \\
\hline
\end{tabular}




\begin{tabular}{|c|c|c|c|c|c|}
\hline & $M$ & $\overline{\mathbf{N}}$ & 0 & $\mathbf{P}$ & 0 \\
\hline 1 & \multirow{2}{*}{\multicolumn{5}{|c|}{$\begin{array}{l}\text { TESTING OF PROTOTYPE BURNERS - WORK CONDUCTED FOR U.S. ARMY, NATICK R\&D CTR } \\
\text { THIS DATABASE (SETUP ON EXCEL 4.0) PROVIDES THE RAW DATA AND CALCULATIONS } \\
\end{array}$}} \\
\hline 2 & & & & & \\
\hline 3 & \multicolumn{4}{|c|}{ NEEDED TO DETERMINE STOVE EMISSIONS WITH DIFFERENT FUEL TYPES } & \\
\hline 4 & Prepared by Wai-Lin Litzke and Yusuf Celebi & & & & \\
\hline 5 & & & & & \\
\hline 6 & Burner Type & ITR & ITR & ITR & ITR \\
\hline 7 & Burner Operating Condition & High/High & Low/Low & Low/High & - Low \\
\hline 8 & Fuel Type & JP-8 & JP-8 & $\mathrm{JP}-8$ & JP-8 \\
\hline 9 & & & & & \\
\hline 10 & Fuel Composition (\% by wt) & & & & \\
\hline 11 & $\% \mathrm{C}$ & 85.7 & 85.7 & 85.7 & 85.7 \\
\hline 12 & $\% \mathrm{H}$ & 14.2 & 14.2 & 14.2 & 14.2 \\
\hline 13 & $\% \mathrm{~S}$ & 0.1 & 0.1 & 0.1 & 0.1 \\
\hline 14 & & & & & \\
\hline 15 & Operating Conditions & & & & \\
\hline 16 & Stack draft, & 0.065 & 0.0575 & 0.063 & 0.0475 \\
\hline 17 & Stack Temp., $\quad F$ & 695 & 545 & 644 & 365 \\
\hline 18 & Stack Temp, K $\quad$ (Ts) & 641 & 558 & 613 & 458 \\
\hline 19 & $\% 02$ measured, dry basis & 16.2 & 18.2 & 16.9 & 19.6 \\
\hline 20 & beta term & 10.69 & 10.69 & 10.69 & 10.69 \\
\hline 21 & alpha & 3.13 & 6.03 & 3.83 & 12.95 \\
\hline 22 & $\%$ Excess Air & 313 & 603 & 383 & 1295 \\
\hline 23 & (1+alpha) & 4.13 & 7.03 & 4.83 & 13.95 \\
\hline 24 & $\mathrm{~kg}$ water $/ \mathrm{kg}$ dry air $=\mathrm{W}$ (ie. ambient $=.01$ ) & 0.01 & 0.01 & 0.01 & 0.01 \\
\hline 25 & & & & & \\
\hline 26 & Products of Combustion & & & & \\
\hline 27 & $\mathrm{CO} 2$, moles & 7.14 & 7.14 & 7.14 & 7.14 \\
\hline 28 & $\mathrm{~N} 2$, moles & 166.24 & 282.64 & 194.09 & 560.80 \\
\hline 29 & $\mathrm{O} 2$, moles & 33.52 & 64.47 & 40.93 & 138.45 \\
\hline 30 & SO2, moles & 0.003 & 0.003 & 0.003 & 0.003 \\
\hline 31 & Water, moles & 10.465 & 12.820 & 11.028 & 18.450 \\
\hline 32 & $\mathrm{Kg}$ dry gas/ $100 \mathrm{Kg}$ fuel $(\mathrm{CO} 2, \mathrm{~N} 2, \mathrm{O} 2, \mathrm{SO} 2)$ & 6042 & 10291 & 7059 & 20447 \\
\hline 33 & $\mathrm{Kg}$ water $/ 100 \mathrm{Kg}$ fuel & 188 & 231 & 199 & 332 \\
\hline 34 & Moisture Content & 0.048 & 0.035 & 0.044 & 0.025 \\
\hline 35 & Mol. Wt. of dry gas, $\mathrm{gm} / \mathrm{mol}$ & 29.200 & 29.051 & 29.148 & 28.946 \\
\hline 36 & Density of dry gas gm/liter at stack temp & 0.555 & 0.635 & 0.580 & 0.771 \\
\hline 37 & $\mathrm{lb} / \mathrm{ft} 3$ & 0.035 & 0.040 & 0.036 & 0.048 \\
\hline 38 & lb dry gas $/ \mathrm{lb}$ fuel & 60.42 & 102.91 & 70.59 & 204.47 \\
\hline 39 & Fuel flowrate, & 0.47 & 0.34 & 0.41 & 0.18 \\
\hline 40 & Fuel flowrate, & 3.13 & 2.26 & 2.70 & 1.15 \\
\hline 41 & lb dry gas/min & 3.15 & 3.87 & 3.17 & 3.93 \\
\hline 42 & dry gas acfm & 90.99 & 97.75 & 87.66 & 81.77 \\
\hline 43 & Stack gas flowrate, & 2451 & 2633 & 2362 & 2203 \\
\hline 44 & & & & & \\
\hline 45 & & & & & \\
\hline 46 & & & & & \\
\hline 47 & & & & & \\
\hline$\overline{48}$ & & & & & \\
\hline 49 & & & & & \\
\hline
\end{tabular}


DATA FOR THE ITR UNIT - JP-8 FUEL

\begin{tabular}{|c|c|c|c|c|c|}
\hline & $\mathbf{M}$ & $\mathbf{N}$ & 0 & $\mathbf{P}$ & Q \\
\hline 50 & Gas Emissions as Measured (dry basis): & & & & \\
\hline 51 & CO - startup peak, $\quad$ ppm & $>5000$ & $>5000$ & $>5000$ & 3900 \\
\hline 52 & CO - steady state, & 15 & 14 & 15 & 13 \\
\hline 53 & CO - shutdown peak, $\quad$ ppm & 15 & 35 & 23 & 13 \\
\hline 54 & NOx & 36 & 15 & 25 & 6 \\
\hline 55 & $\% \mathrm{O} 2$ & 16.2 & 18.2 & 16.9 & 19.6 \\
\hline \multicolumn{6}{|l|}{56} \\
\hline 57 & Particulate Measurements & & & & \\
\hline 58 & Total amount collected, & 0.0036 & 0.0037 & 0.0027 & 0.0027 \\
\hline 59 & Temp. at meter, $\quad \mathrm{F}$ & 86.1 & 80.7 & 79.3 & 79.1 \\
\hline 60 & Diry gas volume sampled, $\quad$ dcf & 61.952 & 63.53 & 61.895 & 60.609 \\
\hline 61 & Dry gas volume sampled, std. cond., dscf & 59.899 & 62.038 & 60.598 & 59.361 \\
\hline 62 & $\begin{array}{l}\text { Concentration of particulates in stack gas, dry } \\
\text { basis, } \\
\text { mg/dscf }\end{array}$ & 0.060 & 0.060 & 0.045 & 0.045 \\
\hline \multicolumn{6}{|c|}{\begin{tabular}{l|l}
63 & 2 \\
\end{tabular}} \\
\hline 64 & Formaldehyde Measurements & & & & \\
\hline 65 & Total mass collected, ug & 42.4 & 37 & 24.8 & 27.6 \\
\hline 66 & Volume sampled, (std. liters) & 96 & 96.9 & 98.5 & 99.74 \\
\hline 67 & Concentration in vol. sampled, $\mathrm{mg} / \mathrm{scm}$ & 0.442 & 0.382 & 0.252 & 0.277 \\
\hline 68 & $\mathrm{mg} / \mathrm{scf}$ & 0.013 & 0.011 & 0.007 & 0.008 \\
\hline 69 & Total formaldehyde emitted, & $2.1561 \mathrm{E}-05$ & $2.7768 \mathrm{E}-05$ & $1.375 \mathrm{E}-05$ & $3.2935 \mathrm{E}-05$ \\
\hline 70 & Concentration of formald. in stack, ${ }^{-} \mathrm{ppm}$ & 0.360 & 0.311 & 0.205 & 0.226 \\
\hline 71 & & & & & \\
\hline
\end{tabular}


PERFORMANCE TEST REPORT - EXHAUST EMISSIONS

FOR THE BABINGTON MULTIFUEL BURNER

W. Litzke, Y. Celebi, and R. Mc Donald

August 1994

Energy Efficiency \& Conservation Division

Department of Applied Science

Brookhaven National Laboratory

Upton, New York 11973

This work was performed under the auspices of the U.S. Department of Energy Washington, D.C. Under Contract No. DE-AC02-76CH00016 


\section{-}




\section{TABLE OF CONTENTS}

SECTION

PAGE

1.0

INTRODUCTION $\ldots \ldots \ldots \ldots \ldots \ldots \ldots \ldots \ldots \ldots \ldots \ldots$

1.1 Objective $\ldots \ldots \ldots \ldots \ldots \ldots \ldots \ldots \ldots \ldots \ldots \ldots \ldots \ldots \ldots \ldots$

1.2 Background $\ldots \ldots \ldots \ldots \ldots \ldots \ldots \ldots \ldots \ldots \ldots \ldots \ldots \ldots$

1.3 Technical Approach $\ldots \ldots \ldots \ldots \ldots \ldots \ldots \ldots \ldots .2$

2.0 MEASUREMENT TECHNIQUE AND INSTRUMENTATION 2

2.1 Description of Burner and Test Operating Conditions ..... 2

2.2 Experimental Arrangement $\ldots \ldots \ldots \ldots \ldots \ldots \ldots \ldots$

2.3 Flue Gas Analyses $\ldots \ldots \ldots \ldots \ldots \ldots \ldots \ldots \ldots \ldots$

2.4 Particulate Emissions $\ldots \ldots \ldots \ldots \ldots \ldots \ldots \ldots \ldots$

2.5 Formaldehyde $\ldots \ldots \ldots \ldots \ldots \ldots \ldots \ldots \ldots \ldots \ldots \ldots$

2.6 Transient Smoke $\ldots \ldots \ldots \ldots \ldots \ldots \ldots \ldots \ldots \ldots \ldots \ldots \ldots \ldots$

3.0 EXPERIMENTAL RESULTS $\ldots \ldots \ldots \ldots \ldots \ldots \ldots \ldots \ldots$

3.1 Emissions Measurements $\ldots \ldots \ldots \ldots \ldots \ldots \ldots \ldots$

3.2 Cold Soak Test $\ldots \ldots \ldots \ldots \ldots \ldots \ldots \ldots \ldots \ldots \ldots, 11$

4.0 GENERAL COMMENTS AND OBSERVATIONS ....... 11

$5.0 \quad$ REFERENCES $\ldots \ldots \ldots \ldots \ldots \ldots \ldots \ldots \ldots \ldots \ldots \ldots \ldots$

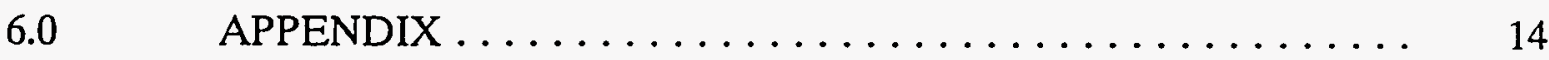

A. Fuels Analyses $\ldots \ldots \ldots \ldots \ldots \ldots \ldots \ldots \ldots \ldots \ldots \ldots \ldots \ldots$

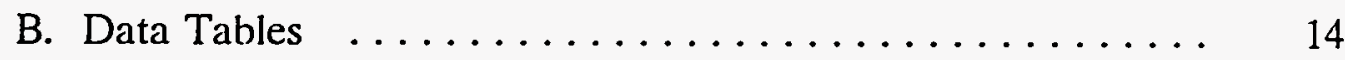




\section{LIST OF FIGURES}

\section{FIGURES}

PAGE

Schematic of Test Sampling System $\ldots \ldots \ldots \ldots \ldots \ldots \ldots, \quad 3$

2

Particulate Emissions Sampling System . . . . . . . . . 6

3

Formaldehyde Sampling Train $\ldots \ldots \ldots \ldots \ldots \ldots \ldots \ldots$

4

Babington Burner - Transient Smoke Numbers during Startup ..

9 


\section{LIST OF TABLES}

TABLES

PAGE

Babington Test Conditions

2 Babington Burner - Carbon Monoxide, Nitrogen Oxides and

Oxygen Content ........................ 8

3 Babington Burner - Particulate Emissions $\ldots \ldots \ldots \ldots \ldots \ldots .9$

4 Babington Burner - Formaldehyde Emissions $\ldots \ldots \ldots \ldots \ldots \ldots$

$5 \quad$ Babington Burner - Results of Cyclic Operation ............ 11 


\subsection{INTRODUCTION}

\subsection{Objective}

The objective of this project is to provide data to the U.S. Army Natick RD\&E Center on the performance of three prototype burners, which have the capability of firing with multiple types of fuels (diesel and JP-8), and the conventional gasoline-fired M-2 burner. The prototype burners are intended to replace the M-2 unit currently used in food cooking appliances in the Army. The burners supplied to Brookhaven National Laboratory (BNL) for the purpose of testing under this project included one M-2 unit, one M-3 prototype unit designed by Natick; one Babington prototype unit designed by Babington Engineering, and one ITR prototype designed by International Thermal Research Ltd. It should be noted, however, that after the project began, Babington Engineering provided an upgraded prototype unit for testing which replaced the unit initially provided by the Natick Center. The M-3 unit replaced the Karcher unit listed in the contract. These arrangements were agreed upon by the Army Project Officer and BNL at the outset of the experimental work.

The test procedures which were described in a Test Method Report allowed for the measurement of the concentrations of specific compounds emitted from the burners. These compounds included oxygen $\left(\mathrm{O}_{2}\right)$, carbon monoxide $(\mathrm{CO})$, oxides of nitrogen $\left(\mathrm{NO}_{x}\right)$ formaldehyde, and particulate emissions. The level of smoke produced was also measured by using a Bacharach Smoke Number system (ASTM Standard D2156).

A performance test report has been prepared for each prototype burner that includes a description of the technology tested, a presentation of the results, and a discussion of practical observations about its operation and recommendations for improvements. This report details the results of the Babington burner only. A comparison of results for all burners will be summarized in a separate report entitled, Comparison of Emissions Characteristics of Prototype Advanced Burners.

\subsection{Background}

The U.S. Army is currently interested in the development of advanced cooking appliances which can be fueled with distillate oil (diesel and JP-8) and deployed in the field. These appliances will be used in semi-enclosed areas and so it is important that the combustion process be consistently clean. Pollutants of potential concern include carbon monoxide, aldehydes, and particulates.

Federal agencies such as the Occupational Safety and Health Administration (OSHA) establish standards for permissible exposure limits to ensure that employees are not exposed to airborne concentrations of specific contaminants that exceed these limits. The current accepted exposure limit over an 8-hour period for $\mathrm{CO}$ is $50 \mathrm{ppm}$. The term "aldehydes" refers to a family of compounds with different levels of toxicity and concentration in combustion product exhaust. The dominant aldehyde in both exhaust products and the atmosphere is formaldehyde which has an 8-hour average exposure limit of $0.75 \mathrm{ppm}$. In 
automotive engine exhaust the total hydrocarbon emissions can be in the 100's of ppm range and aldehydes may be about $1 / 3$ of the total. Nitrogen oxides $\left(\mathrm{NO}_{x}\right)$ generated from fuel oil combustion consist mostly of nitric oxide $(\mathrm{NO})$ and nitrogen dioxide $\left(\mathrm{NO}_{2}\right)$ which have an 8-hour average exposure limit of $25 \mathrm{ppm}$ and a maximum limit of $5 \mathrm{ppm}$, respectively.

\subsection{Technical Approach}

In this project BNL has performed evaluation tests on prototype burners in support of the Army's efforts to develop advanced field cooking equipment. The basic test arrangement that was used is illustrated in Figure 1. All combustion products from the cooking appliance or prototype burner were collected in a hood and dilution tunnel arrangement. The flow in the dilution tunnel includes both combustion products and room air. The concentration of all pollutants was measured directly in the tunnel and, using fuel analyses information, the amount emitted was be related to the mass of fuel used. The burner fuel flow rate was measured and pollutant emissions are reported on: as measured, corrected to fixed excess air, mass/hour, mass per mass of fuel, and mass per unit of fuel heating value basis.

Testing during steady state operation consisted of turning the unit on, allowing it to run for the duration of the sampling time and then turning the unit off. For units that required a significant warmup period and did not readily ignite, such as the M2 and M3 units, steady state operation consisted of only the duration when the unit was firing stably. The long outdoor start-up period precludes any detailed transient measurements. For the ITR and Babington units, the start-up and shutdown emissions (transients) were also characterized. Clean transient operation is likely to lead to lower maintenance needs in the long term.

The fuels used in these tests consist of diesel (grade D-2), a kerosine type jet fuel (grade JP-8), and automotive gasoline. D-2 diesel has been specifically formulated for testing of equipment and is commonly used as a standard for testing mobile engines; JP-8 meets military specification MIL-T-83133. An analysis for each of these fuels was provided by Phillips 66 Company and they are included in the appendix of this report. The gasoline used for the M-2 burner was an unleaded regular grade of fuel.

\subsection{MEASUREMENT TECHNIQUE AND INSTRUMENTATION}

\subsection{Description of Burner and Test Operating Conditions}

The Babington burner consists of a unique air-atomizing system that supplies the fuel for combustion. Instead of a nozzle, the fuel is delivered to the outside of a hollow hemispherical surface which contains a narrow slit. The liquid fuel spreads out over the surface in a thin film; compressed air supplied by a small compressor exits the narrow slit under this film and atomizes the fuel. The resulting dispersion of fine liquid drops is mixed with primary combustion air supplied by a blower and ignited. A set of controls allows for variable heat output, and with a transfer pump automatic filling of the integral fuel tank. A power switch 


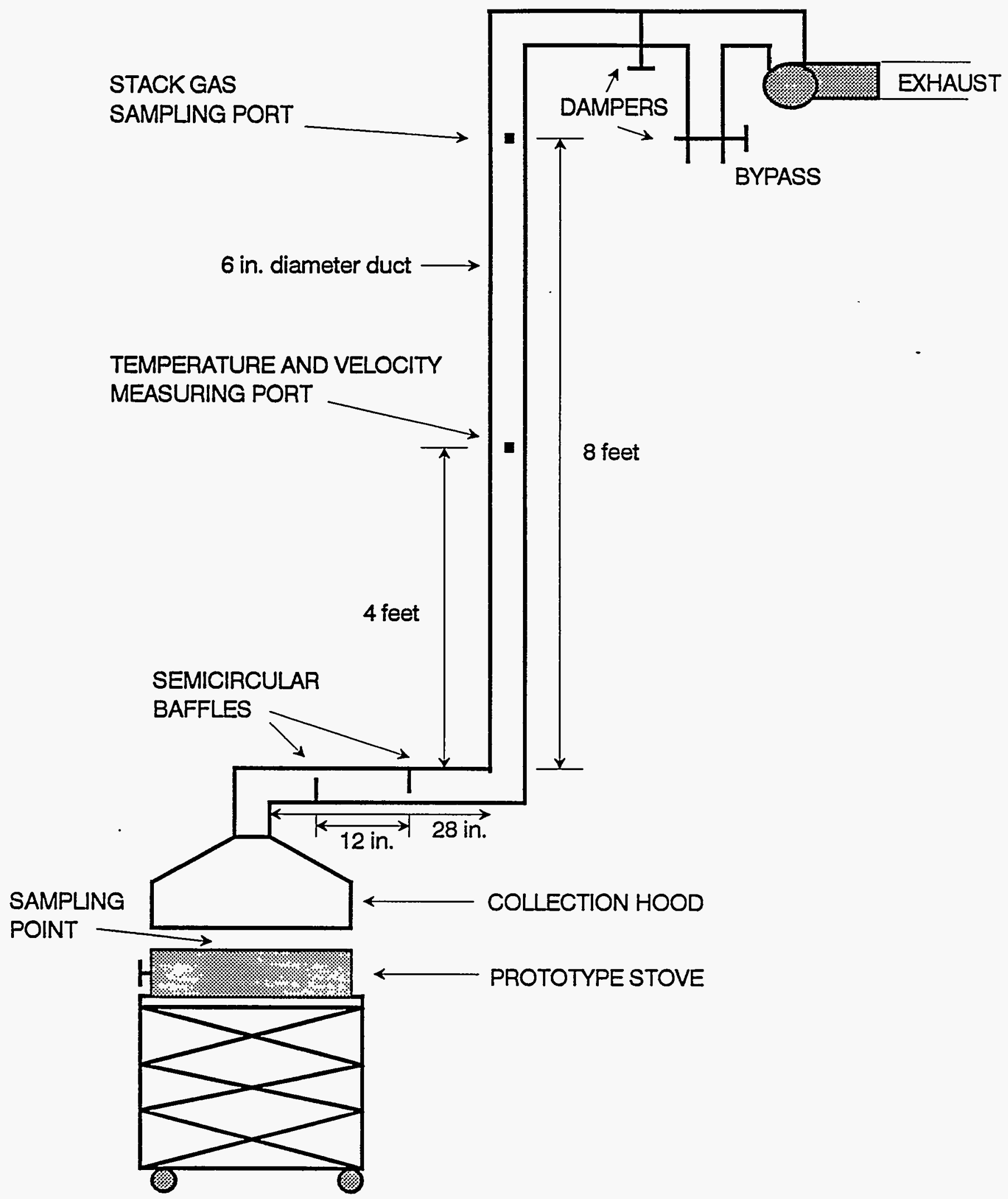

Figure 1. Schematic of Test Sampling System 
turns on the unit and a 12-volt battery supplies the power. A firing cycle consists of a short prepurge period (18 seconds) when the burner is switched on and a longer postpurge period (about 2.5 minutes) when it is turned off.

A matrix of tests was conducted to evaluate overall performance of the prototype burner, emissions characteristics, and general ease of operation with respect to changes in fuel type, firing rate, ambient temperature, and mode of operation. Table 1 summarizes the operating conditions of each test.

\begin{tabular}{|c|c|c|c|c|}
\hline Test & Fuel Type & $\begin{array}{c}\text { Firing Rate } \\
\text { (Btu/hr) }\end{array}$ & $\begin{array}{c}\text { Firing } \\
\text { Rate } \\
(\mathrm{gph})\end{array}$ & $\begin{array}{c}\text { Operating } \\
\text { Mode }\end{array}$ \\
\hline HIGH & Diesel & 57,500 & 0.43 & Steady State \\
\hline MID & Diesel & 45,400 & 0.34 & Steady State \\
\hline LOW & Diesel & 20,600 & 0.15 & Steady State \\
\hline HIGH & JP-8 & 46,000 & 0.35 & Steady State \\
\hline MID & JP-8 & 29,000 & 0.22 & Steady State \\
\hline LOW & JP-8 & 18,700 & 0.14 & Steady State \\
\hline Cyclic & Diesel & 57,500 & 0.43 & Transient \\
\hline Cyclic & JP-8 & 46,000 & 0.35 & Transient \\
\hline HIGH & JP-8 & 46,000 & 0.35 & Cold Soak \\
\hline
\end{tabular}

Table 1. Babington Test Conditions

The range of firing rate was determined to be 20,600 to $57,500 \mathrm{Btu} / \mathrm{hr}$ for diesel fuel, and 18,700 to $46,000 \mathrm{Btu} / \mathrm{hr}$ for JP-8.

"Steady State" means that the test sequence consists of a startup, a continuous run for the duration of the sampling time of 100 minutes, and then shutdown. This total sampling time allows for an adequate amount of particulate matter and formaldehyde to be collected in the sampling trains as well as allow observations to be made of the burner performance over this period. The particulate and formaldehyde concentrations determined, therefore, represent time-averaged values for this entire test. "Transient" tests consist of a succession of startups and shutdowns of the unit over several cycles to obtain the average particulate concentrations over these transient periods. While it is not expected that total emissions from cyclic operation will be very important for the Army's application it may be helpful to identify designs which have particularly difficult starts and stops. 
Almost all of the tests were performed under ambient temperatures of $68-75^{\circ} \mathrm{F}$ $\left(20-24^{\circ} \mathrm{C}\right)$. For the Babington and ITR burners a startup test after a cold soak was done. The cold soak test required that the stove be stored in an insulated coldbox filled with dry ice until the unit reached a temperature of about $-40^{\circ} \mathrm{F}\left(-40^{\circ} \mathrm{C}\right)$. A fan was installed to circulate the air within the box to ensure uniform temperatures. In addition, thermocouples were installed in several locations on the unit to monitor component temperatures. The stove was then brought out of the box after 6-8 hours of soaking and turned on immediately to determine operability of the unit.

\subsection{Experimental Arrangement}

The dilution tunnel system collects all of the combustion products emitted from the burner into the hood where they are mixed with some room air which is also drawn in. By adjusting the dampers in the bypass system the induced draft could be adjusted such that the amount of dilution with room air was minimized. Thermocouples were set up along the 6 in. diameter duct at the sampling ports to measure stack gas temperatures. The centerline flue gas velocity was measured with a pitot tube upstream of the stack gas sampling port.

\subsection{Flue Gas Analyses}

In the dilution tunnel oxygen content $(\mathrm{O} 2)$ of the flue gas, carbon monoxide $(\mathrm{CO})$ and oxides of nitrogen (NOx) were measured in real-time during each test. The oxygen content which was measured with a paramagnetic analyzer (Beckman Model 755) was used to determine the excess air level. Carbon monoxide was measured with an infrared analyzer (Rosemount Analytical Model 880). $\mathrm{NO}_{\mathrm{x}}$ was measured with a chemiluminescent analyzer (Beckman Model 955). A value reported for the $\mathrm{CO}$ during startup or shutdown represents the peak value observed during the transient period; the steady state value represents the average during the firing period. NOx generally increases during startup, reaches a steady level., and then decreases at shutdown; the values reported represent the average steady state concentrations. $\mathrm{CO}$ and $\mathrm{NO}_{\mathrm{x}}$ concentrations are presented in parts per million (ppm) and $\mathrm{O} 2$ in $\%$ by volume of stack gas. By convention and for comparison, emissions from stationary combustion choices are corrected for the differences in excess air and are represented at fixed. $3 \% \mathrm{O} 2$.

A different approach was used to determine particulate and aldehyde emissions which provided a good measurement for these contaminants at low concentrations. The methods which will be described in further detail in the following sections require that integrated samples of flue gas be collected and then analyzed. In this manner, average emissions are determined for these contaminants over the entire test sequence.

\subsection{Particulate Emissions}

Particulate emissions are determined by the amount of material collected, by weight, on a glass fiber filter from the volume of flue gas sampled. The flue gas was sampled

directly from the dilution tunnel with a standard EPA Method 5 sampling train [1]. The 
sampling train, shown in Figure 2, consists of a stainless steel nozzle and filter holder with a preweighed glass fiber filter, a set of glass impingers kept at $32 \mathrm{~F}(0 \mathrm{C})$, a sampling pump, and a dry gas meter that measures the volume of dry gas sampled. The filter remains at the same temperature as the flue gas at the sampling point, which in these test cases is above the water or sulfuric acid dew point. The filter catch and materials washed from the nozzle probe were weighed to obtain the total particulates collected.

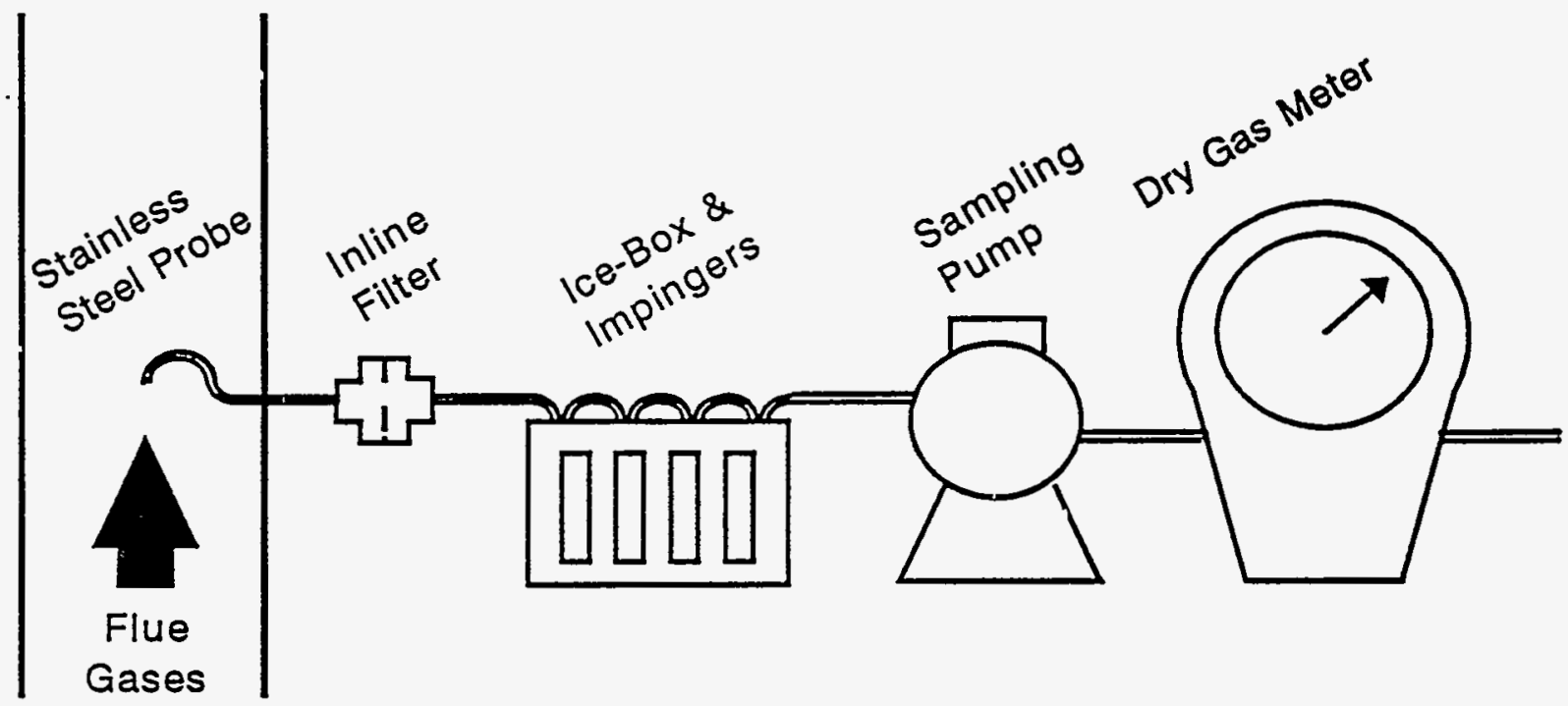

Figure 2. Particulate Emissions Sampling System

\subsection{Formaldehyde}

A simple and quick, colorimetric method of analysis was used to determine formaldehyde concentrations which was derived from NIOSH Method 3500 [2]. This standard provides a monitoring method that applies to occupational exposure to airborne formaldehyde in the work area. It was used in these tests to draw samples directly from the dilution tunnel to obtain maximum possible contaminant levels in the stack gas. The sampling setup for these measurements is shown in Figure 3. Gas samples were bubbled through a set of glass impingers containing sodium bisulfite solution where formaldehyde is absorbed. A reaction of this solution with chromotropic acid and sulfuric acid yields a product that absorbs in the visible spectrum at $580 \mathrm{~nm}$ wavelength. Determination of formaldehyde concentrations is based on the absorbance measured.

Since this method is used to measure exposure levels at ambient temperatures a glass heat exchanger was added to the standard sampling train so that the sampled gas, which was typically above $300^{\circ} \mathrm{F}$, was allowed to cool to about $70^{\circ} \mathrm{F}$ before entering the sample impingers. 
A maximum sample of $3.53 \mathrm{ft}^{3}$ (100 liters) collected gives a detection level as low as $0.02 \mathrm{ppm}$. A test run for 100 minutes at $1 \mathrm{liter} / \mathrm{min}$ sampling rate provides the time-weighted average concentration of formaldehyde for that period of time. Since most of the pollutants were emitted during the transient period (ie. startup), which usually lasts for about 1-2 minutes, the actual peak concentrations would be somewhat higher than the average value. An estimate of peak concentrations was obtained by cycling the burner such that enough gas is sampled during startups and shutdowns over successive cycles to do the analysis.

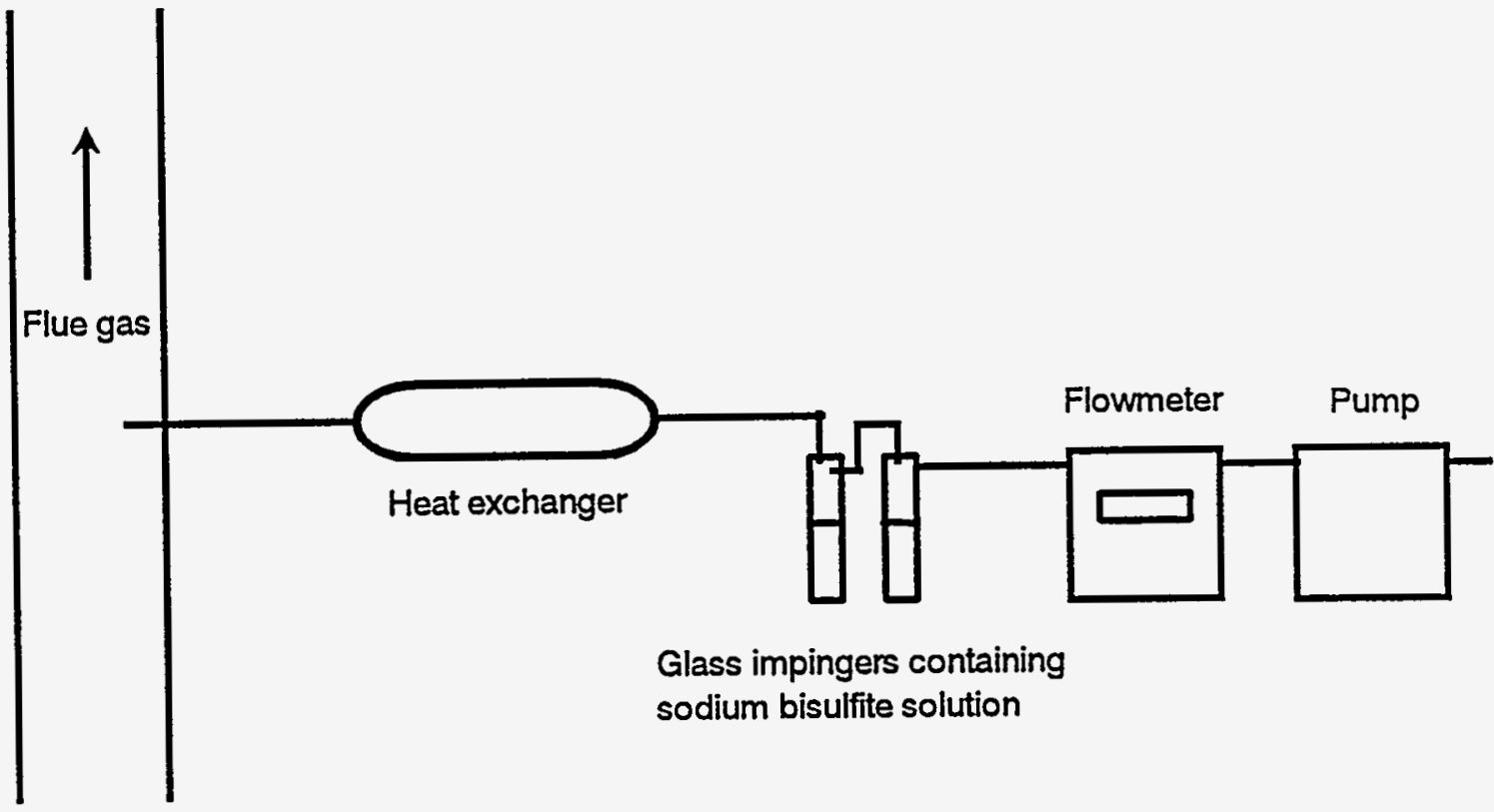

Figure 3. Formaldehyde Sampling Train

\subsection{Transient Smoke}

Smoke is usually generated during the startup and/or shutdown periods of the firing cycle. The method used to determine smoke density is ASTM standard D2156 and has been expressed as the Bacharach Smoke Number. A standardized hand-pump was used to draw a fixed volume of flue gas through filter paper. The darkness of the spot is compared on a 0-9 scale on the smoke chart. During the startup transient multiple samples were taken to obtain a smoke number versus time curve. The amount of smoke dissipated after startup once the burner was firing steadily.

\subsection{EXPERIMENTAL RESULTS}

\subsection{Emissions Measurements}

Refer to Table 2 for some of the experimental results obtained for gaseous emissions during typical stove operation. Values for carbon.monoxide (CO), oxides of nitrogen (NOx) and oxygen content (\%O2) have been provided on an "as measured basis" which are direct 
readings of the flue gas measurements taken from the dilution tunnel, and emissions corrected to $3 \%$ oxygen content. The corrected values provide a common basis for comparison among different burners and different modes of operation. However, it could be reasonable to say that the "as measured" values are maximum concentrations that would be observed when the stoves are used in an open system in which the ambient air provides the dilution. The Babington burner usually generates higher carbon monoxide levels at the beginning and at the end of a firing cycle; during the steady firing period the $\mathrm{CO}$ is low. These tests show no correlation between firing rate and fuel type with respect to $\mathrm{CO}$ emissions. The values reported for NOx are the average observed values during the steady firing period and they generally increase with firing rate.

\begin{tabular}{|c|c|c|c|c|c|c|}
\hline Burner Type & Babington & Babington & Babington & Babington & Babington & Babington \\
\hline Burner Operating Condition & High & Mid & Low & High & Mid & Low \\
\hline Fuel Type & Diesel & Diesel & Diesel & JP-8 & JP-8 & JP-8 \\
\hline \multicolumn{7}{|c|}{ Gas Emissions as Measured (dry basis): } \\
\hline CO - startup peak, $\quad$ ppm & 25 & 18 & 94 & 21 & 109 & 43 \\
\hline CO - steady state, & 6 & 7 & 4 & 8 & 6 & $\overline{4}$ \\
\hline CO - shutdown peak, & 30 & 16 & 4 & 27 & 18 & 9 \\
\hline NOx & 37 & 24 & 14 & 34 & 22 & 16 \\
\hline$\% \mathrm{O} 2$ & 18.2 & 18.7 & 19.6 & 19.1 & 19.6 & 20 \\
\hline \multicolumn{7}{|l|}{ Emissions corrected to $3 \% \mathrm{O} 2$} \\
\hline $\begin{array}{ll}\text { CO - startup, } & \text { ppm }\end{array}$ & 161 & 141 & 1209 & 199 & 1401 & 774 \\
\hline CO - steady state, & 39 & 55 & 51 & 76 & 77 & 72 \\
\hline CO - shutdown peak, & 193 & 125 & 51 & 256 & 231 & 162 \\
\hline NOx & 238 & 188 & 180 & 322 & 283 & 288 \\
\hline & & & & & & \\
\hline
\end{tabular}

Table 2. Babington Burner - Carbon Monoxide, Nitrogen Oxides and Oxygen Content

The results of particulate emissions are shown in Table 3 and are given in several different units. The most common expressions are in the form of mass of pollutant/mass of fuel, or mass of pollutant/energy input. To convert from the measured stack gas concentration to these units the measured oxygen content of flue gas and an assumed typical fuel composition (for diesel and JP-8) were used to determine the excess air and the total flue gas flowrate. The results of all calculations are found in the appendix. The amount of particulates emitted as reported are averaged values for the test sequence - startup, steady firing, and shutdown which totals to a sampling period of about 100 minutes. Most of the particulates were generated during startup and the following summary of the transient smoke measurements helps to support this observation. Particulate emissions ranged from 0.010 to $0.014 \mathrm{lb} / \mathrm{million}$ Btu over the full firing range for both fuels, and is independent of the fuel type or firing rate. 


\begin{tabular}{|c|c|c|c|c|c|c|}
\hline Burner Type & Babington & Babington & Babington & Babington & Babington & Babington \\
\hline Burner Operating Condition & High & Mid & Low & High & Mid & Low \\
\hline Fuel Type & Diesel & Diesel & Diesel & JP-8 & $\mathrm{JP}-8$ & $\mathrm{JP}-8$ \\
\hline \multicolumn{7}{|l|}{ Particulate Measurements } \\
\hline $\begin{array}{l}\text { Concentr. of particulates in stack gas, } \\
\mathrm{mg} / \text { dscf }\end{array}$ & 0.094 & 0.077 & 0.067 & 0.069 & 0.046 & 0.038 \\
\hline $\begin{array}{l}\text { Total particulates emitted, } \\
\mathrm{lb} / 100 \mathrm{lb} \text { fuel }\end{array}$ & 0.023 & 0.021 & 0.027 & 0.026 & 0.021 & 0.021 \\
\hline Total particulates emitted, $\mathrm{mg} / \mathrm{hr}$ & 318 & 224 & 135 & 269 & 137 & 91 \\
\hline Total particulates emitted, $\mathrm{lb} / \mathrm{M}$ & 0.012 & 0.011 & 0.014 & 0.013 & 0.010 & 0.011 \\
\hline
\end{tabular}

Table 3. Babington Burner - Particulate Emissions

Figure 4 shows the relationship of the smoke density (smoke number) with respect to time during startup. A comparison is made between fuel type, diesel and JP-8, and firing rate which is indicated by High, Mid, and Low. Results show that the smoke levels generated

Bacharach smoke no.

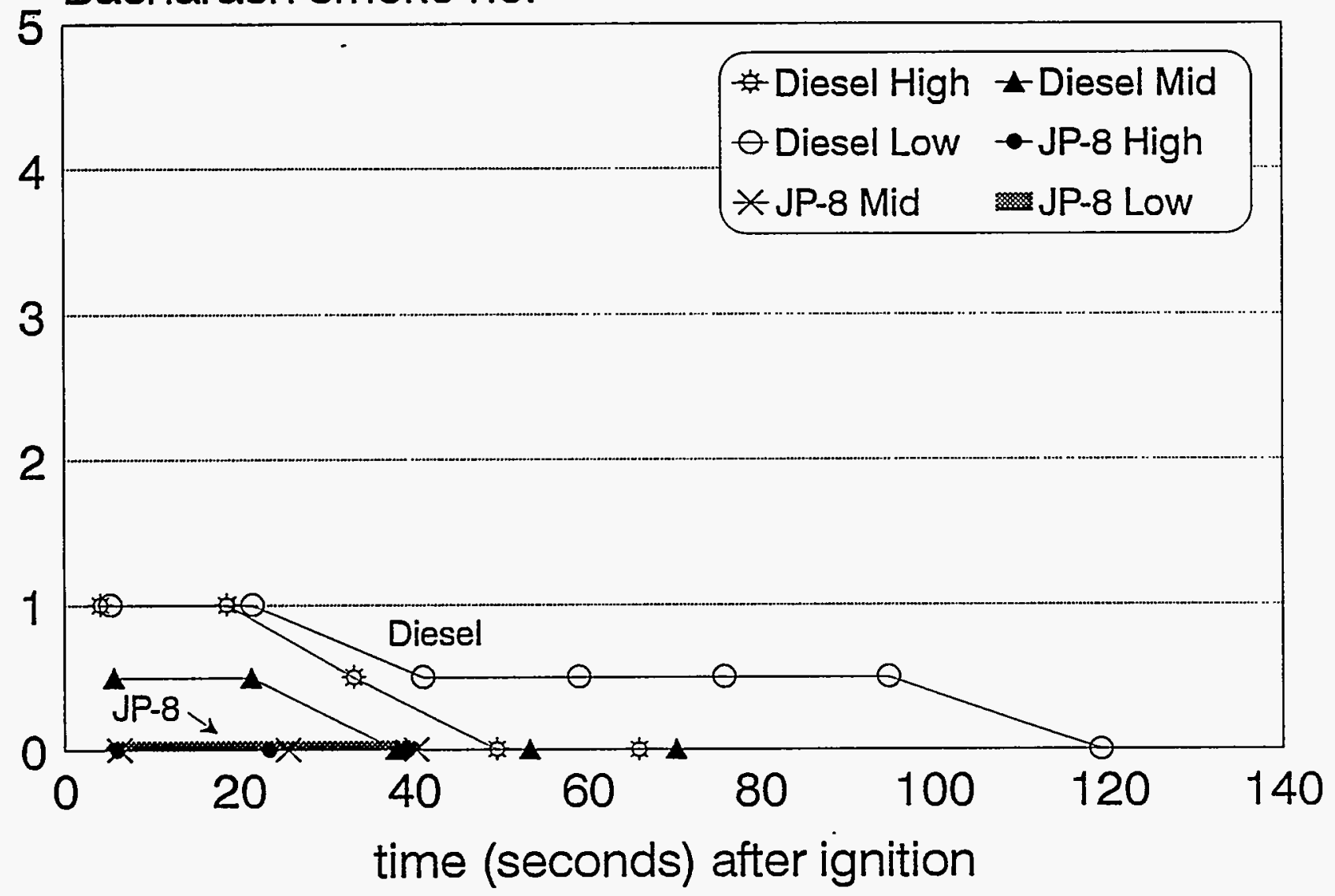

Figure 4. Babington Burner - Transient Smoke Numbers during Startup 
during startup are low with a maximum of Smoke No. 1 for the diesel fuel and no smoke for JP-8. The transient period at low firing rate with diesel fuel is much longer than at the higher firing rates.

A summary of the formaldehyde measurements is shown in Table 4 with values on an "as measured basis" which are the average stack concentrations, and with values that were corrected to $3 \%$ O2. In general, these emissions are very low especially when dilution with ambient air is considered, which may be the case under actual operating conditions in an open-fired system. Using these concentrations as guidelines they currently meet the permissible exposure limit of $0.75 \mathrm{ppm}$ although ambient exposure monitoring according to OSHA requirements would be needed to determine true values.

\begin{tabular}{|l|l|l|l|l|l|l|}
\hline Burner Type & Babington & Babington & Babington & Babington & Babington & Babington \\
\hline Burner Operating Condition & High & Mid & Low & High & Mid & Low \\
\hline Fuel Type & Diesel & Diesel & Diesel & JP-8 & JP-8 & JP-8 \\
\hline & & & & & & \\
\hline Formaldehyde Measurements & & & & & & \\
\hline $\begin{array}{l}\text { Avg. concentration of } \\
\text { formaldehyde in stack, ppm }\end{array}$ & 0.042 & 0.032 & 0.033 & 0.015 & 0.008 & 0.010 \\
\hline $\begin{array}{l}\text { Avg. formaldehyde concentration } \\
\text { corrected to 3\% O2. ppm }\end{array}$ & 0.27 & 0.25 & 0.43 & 0.14 & 0.11 & 0.18 \\
\hline
\end{tabular}

\section{Table 4. Babington Burner - Formaldehyde Emissions}

A set of data was taken in a "cyclic" mode of operation to generate several transient periods by turning the burner on and off successively during sampling for formaldehyde and particulates. This allows for an adequate amount of material to be collected for measurements and provides an estimate of the contribution of emissions from the transient periods. Startup periods are not necessarily the same during each cycle and the duration is determined by the approximate length of time it takes the $\mathrm{CO}$, which is measured in realtime, to decrease to its typical steady state levels. Although the prototype cookstoves have not been designed to operate in such a fashion, an estimate could be made of the average startup emissions. In addition, this data provides a relative comparison of the ease of startup for the different fuel types. For these tests with both diesel and JP-8, only the highest firing rate was considered and the results are tabulated as follows in Table 5. 


\begin{tabular}{|l|c|c|}
\hline & Diesel & JP-8 \\
\hline Total particulates emitted, $\mathrm{lb} / 100 \mathrm{lb}$ fuel & 0.045 & 0.067 \\
\hline $\begin{array}{l}\text { Actual concentration of formaldehyde } \\
\text { in stack, ppm }\end{array}$ & 0.21 & 0.51 \\
\hline
\end{tabular}

Table 5. Babington Burner - Results of Cyclic Operation

Startups emissions are low for both diesel and JP-8 fuels; the differences observed are not significant. These startup emissions are much larger than the average emissions during typical operation of the stove when the burners are normally allowed to run in a steady state mode.

\subsection{Cold Soak Test}

The cold soak test consisted of cooling the entire Babington unit in a cold-box containing dry ice for several hours to a temperature of at least $-40^{\circ} \mathrm{F}$. Recognizing that the prototype unit had not been originally designed for the cold soak test, the circuit board that controls all of the major burner components was removed and therefore not chilled in the same manner in order to prevent damage to the board itself from condensation. The unit was then brought out of the box and turned on in order to evaluate its operating characteristics. The temperature of several components were monitored as the tests continued. All of the components operated upon startup and ignition of the flame was successful.

\subsection{GENERAL COMMENTS AND OBSERVATIONS}

The Babington multi-fuel burner unit received from Natick RD\&E was not tested beyond an initial test firing stage for two reasons. First, Babington Engineering, Inc. requested and obtained approval from the Natick RD\&E technical representative to allow Brookhaven to test a newer, more advanced, prototype design. The test results reported in this document reflect testing of this advanced prototype unit supplied directly to BNL by Babington Engineering, Inc. The second reason is, that the first unit exhibited a problem after long periods of operation where the unit would, on shutdown, flare-up from hot fuel vapor auto-igniting from the residual heat in the combustion chamber. For this to happen, the fuel in the atomization chamber must have vaporized indicating that the fuel temperature was quite high. Natick RD\&E had also observed a problem with odors from the unit on shut down, prior to sending the first unit to BNL for tests. The second unit, the advanced prototype, did not exhibit either problem. The newer design of the Babington unit specifically addressed resolution of the problem by insulating the fuel system from heat feedback from the combustion chamber and the control system provided an extra measure by providing a post-purge period to vent the combustion chamber and provide cooling. 
The Babington combustion system used in the prototype multi-fuel burner is almost identical to that used in the Airtronic burner manufactured by the Bentone-Electro Oil Company in Sweden. The D.C. powered ancillary components, including the air compressor, fuel pump, and air blower are all different than the Airtronic system which was based on a single A.C. motor driven power unit.

The prototype multi-fuel burner is powered by a 12 volt D.C. source (internal battery or external power converter) with an on-board fuel tank, and conforms to geometry constraints imposed by its intended use by the Army. The combustion head is a proven design with several years of use in the European residential heating market. The multi-fuel burner system tested at BNL for Natick RD\&E operated with a push button control for onoff and a single turn knob control to vary firing rate. The unit is controlled by a microprocessor-based control system that will allow the manufacturer to fine-tune the system's performance and lock it in for production. Ignition is accomplished by a high voltage spark formed across an air gap between two electrodes. Visual observations of the burner during start-up ignition and shut-down firing Diesel or JP-8 were clean and sharp. The unit fired and functioned normally during the $-40^{\circ} \mathrm{F}$ cold soak test firing JP-8 fuel.

The duration of a typical test to measure emissions lasted 100 minutes. During most of the tests BNL observed a downward shift in the Oxygen concentration in the combustion gases or, in other words, an increase in the excess air level. This upward shift in excess air ranged from zero percent in one case to a maximum of $18.8 \%$ in another. This occurred when firing either Diesel or JP-8 fuel and most noticeable at the higher firing rates. A decrease in fuel delivery and/or an increase in combustion air delivery to the burner could explain this. The more probable case is a decrease in fuel delivery rate. If the air supply is assumed to be constant this would mean a shift in fuel flow ranging from $0 \%$ to $15 \%$ was observed by BNL. One possible explanation is that the fuel temperature may increase with time and the associated changes in viscosity, density, and surface tension may all cause the film thickness formed on the burner's hemispherical atomizer surfaces to decrease. This would tend to reduce the amount of fuel being atomized. A shift towards higher excess air levels will dilute "as measured" emission concentrations. A shift in this range would not be expected to cause any problems in the combustion process. The manufacturer should however verify BNL's observation and address the cause and effects to determine what is actually occurring and determine if it is significant to the intended application.

The unit under BNL control operated reliably throughout the test series with the exception of a loose air line which needed to be refastened and clamped to resolve the problem and continue operation. It is recommended that the manufacturer investigate alternative air line materials and fitting to prevent this from being a problem in the future. The prototype unit as tested appeared to be very tight in its layout geometry and use of available space, this may pose a problem with regard to maintenance. The manufacturer has stated its intentions to redesign the system to provide better access for maintenance and repair and to provide a clevis pin mounting for the burner. This would allow the burner to be removed for bench testing, repair, or replacement as needed in the field. 


\subsection{REFERENCES}

[1] EPA Code of Federal Regulations, 40 CFR Part 60, Appendix A, Method 5, 1990.

[2] National Institute for Occupational Safety and Health, NIOSH Manual of Analytical Methods, Third edition, 1989. 


\subsection{APPENDIX}

\section{A. FUELS ANALYSES}

This section contains the analyses for the test fuels D-2 Diesel and JP-8.

\section{B. DATA TABLES}

This section contains information on the operating parameters recorded during each set of tests, fuel composition, measured and calculated data to determine emission factors. Results have been provided for both diesel and JP-8 fuels. 


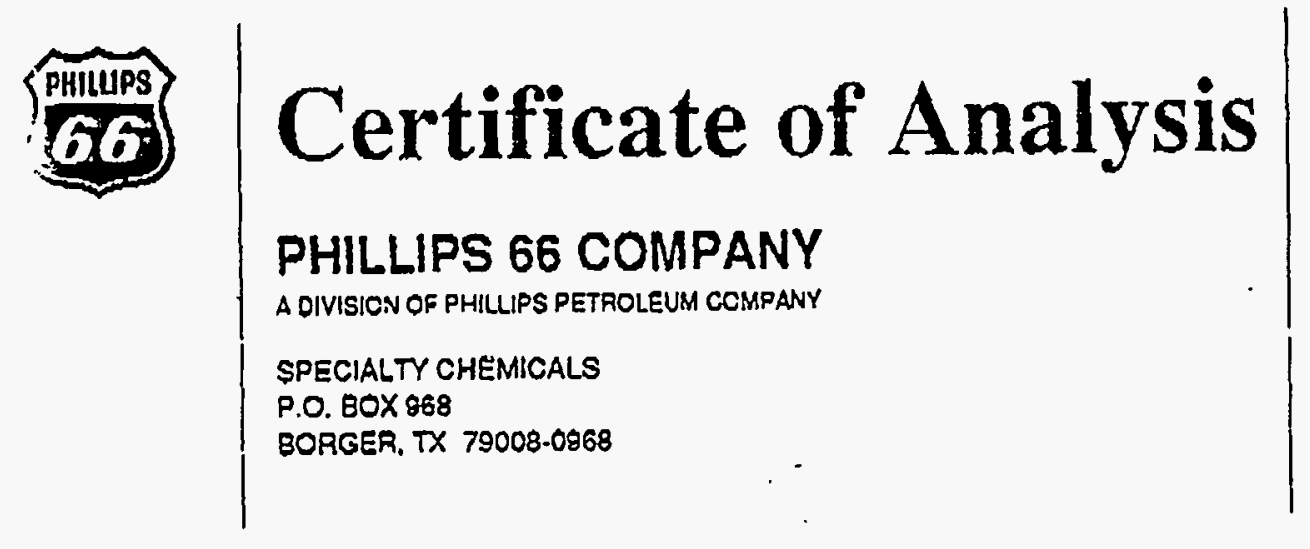

EORD CUSTOM D-2 DIRSEI EUBT IOT $R-287$

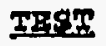

API Gxavity

SuIfur

Elash Point, EM, ${ }^{\circ}$

Viscosity, cs $40 \mathrm{C}$

Particulate Matter (mg/l)

Poux Point

cloud point

DISTIITATIOA, $0-86, \circ \mathrm{O}$

IB\%
$5 \%$
$10 \%$
158
$20 \%$
$30 \%$
$40 \%$
$50 \%$
$60 \%$
$70 \%$
$80 \%$
$90 \%$
$95 \%$
EP
LO88
Re8idue

FYDROCARBOA TYPE, VOLS

Axomatics

olefins

Saturates

Cetane Index

Cetane Numbex

GRA: BE : jam

$05 / 09 / 1994$
DATY OP SEIELABAY

$03-05-93$

COSTONER ORDER NO. 4171

INY./RBON. NO. 230759

\section{SPECIFICAMIONS}

$33-37$

$0.20-0.50$

$130 \mathrm{Min}$.

2.0-3.2

$15 \mathrm{Max}$.

Report

$+3$

Report

$340-400$

$400-460$

$470-540$

$550-610$

$580-660$

0.0

1.6

$$
\begin{array}{r}
34.9 \\
1.7 \\
53.4 \\
\hline 100.0
\end{array}
$$

$27-35$

47

45

$43-47$

$42-50$ 


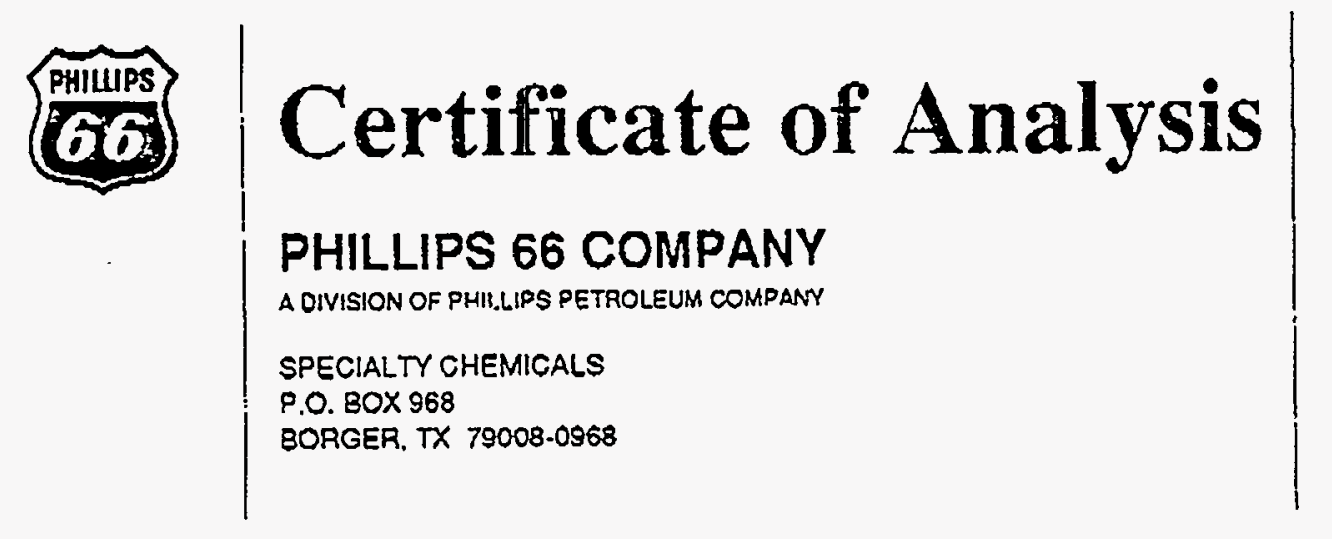

\author{
DAIE OF BHIPHIST \\ $04-06-94$ \\ CUBTCITH ORDER NO. \\ 728979 \\ IXV./Rzep. No. \\ 441400 \\ $1 \times 54$ GALION DRUM
}

\section{TESTS}

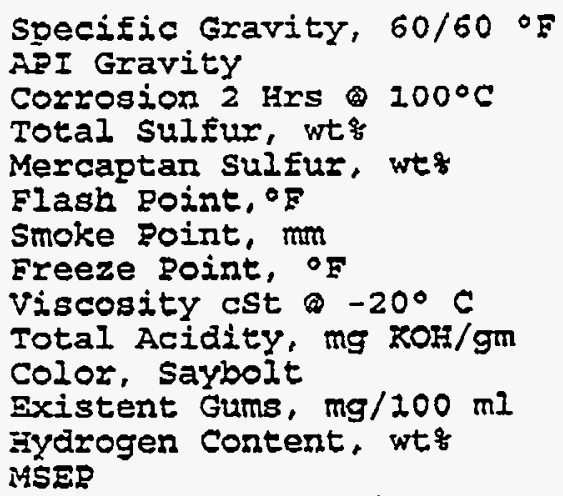

KIIT-T-83133C JP-8 LOT R-324

\section{로SUITS}

0.7905
47.5
$1 a$
0.0943
.00032
132
25
-60
0.010
$30+$
0.31
14.2
87
9
18672
0.24
1
0
166

337

360

366

368

373

379

385

392

401

412

428

455

$\$ 80$

508

0.8

1.2

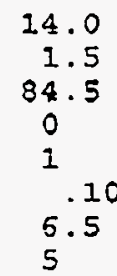

SPECIEICATIOSS ML-4HOD

$0.775-0.8400$
$37.0-51.0$
$1 \mathrm{Max}$
$0.30 \mathrm{Max}$
$0.002 \mathrm{Max}$
$100 \mathrm{MIn}$
$25.0 \mathrm{Min}$
$-53 \mathrm{Max}$
$8 \mathrm{Max}$
$0.015 \mathrm{Max}$
Report
$7.0 \mathrm{Max}$
$13.4 \mathrm{Min}$
$70 \mathrm{Min}$
$15 \mathrm{Max}$
$18.400 \mathrm{Min}$
$1 \mathrm{Max}$
$1 \mathrm{M} \mathrm{Max}$
$2 \mathrm{Max}$
$150-600$

ASTM D-4052

ASTM D-1298

ASTM D-130

ASIM D-2622

ASTM D-3227

ASTM D-93

ASIM D-1322

ASTM D-2386

ASIM D-445

ASTM D-3242

ASTM D- 156

ASTM D-381

ASTM D-3701

ASTM D-3948

ASTM D-3338

ASTM D-2276

ASTM D-1094

ASTM D-2550

ASTM D-2524

AsIM $0-86$

Report

401 Max

$572 \operatorname{Max}$

$1.5 \mathrm{Max}$

1. 5 Max

25 Max
5 Max
25 Max
$<3$
$0.10-0.15$
$6.0-8.4$
Report

ASIX: D-2319

ASTM D-3241
ASTM D-3241 


\begin{tabular}{|c|c|c|c|c|}
\hline & $\mathbf{V}$ & $\mathbf{w}$ & $\mathbf{x}$ & $\mathbf{Y}$ \\
\hline 1 & \multicolumn{4}{|c|}{ TESTING OF PROTOTYPE BURNERS - WORK CONDUCTED FOR U.S. ARMY, NATICK R\&D CTR } \\
\hline 2 & \multicolumn{4}{|c|}{ THIS DATABASE (SETUP ON EXCEL 4.0) PROVIDES THE RAW DATA AND CALCULATIONS } \\
\hline 3 & \multicolumn{4}{|c|}{\begin{tabular}{|l|l} 
NEEDED TO DETERMINE STOVE EMISSIONS WITH DIFFERENT FUEL TYPES & \\
\end{tabular}} \\
\hline 4 & Prepared by Wai-Lin Litzke and Yusuf Celebi & & & \\
\hline \multicolumn{5}{|c|}{ res l } \\
\hline 6 & Burner Type & Babington & Babington & Babington \\
\hline 7 & Burner Operating Condition & High & Mid & Low \\
\hline 8 & Fuel Type & Diesel & Diesel & Diesel \\
\hline \multicolumn{5}{|l|}{9} \\
\hline 10 & Fuel Composition (\% by wt) & & & \\
\hline 11 & $\% \mathrm{C}$ & 87.3 & 87.3 & 87.3 \\
\hline 12 & $\% \mathrm{H}$ & 12.5 & 12.5 & 12.5 \\
\hline 13 & $\% \mathrm{~S}$ & 0.21 & 0.21 & 0.21 \\
\hline \multicolumn{5}{|c|}{14} \\
\hline 15 & Operating Conditions & & & \\
\hline 16 & Stack draft, & 0.06 & 0.055 & 0.05 \\
\hline 17 & Stack Temp., $\quad$ F & 528 & 424 & 353 \\
\hline 18 & \begin{tabular}{|ll} 
Stack Temp, $\mathrm{K}$ & (Ts) \\
\end{tabular} & 549 & 491 & 451 \\
\hline 19 & $\%$ O2 measured, dry basis & 18.2 & 18.7 & 19.6 \\
\hline 20 & beta term & 10.41 & 10.41 & 10.41 \\
\hline 21 & alpha & 6.07 & 7.59 & 13.04 \\
\hline 22 & \%Excess Air & 607 & 759 & 1304 \\
\hline 23 & $(1+$ alpha) & 7.07 & 8.59 & 14.04 \\
\hline 24 & $\mathrm{~kg}$ water $/ \mathrm{kg}$ dry air $=\mathrm{W}$ (ie. ambient $=.0 \mathrm{l}$ ) & 0.01 & 0.01 & 0.01 \\
\hline \multicolumn{5}{|c|}{ o } \\
\hline \multicolumn{5}{|c|}{ Products of Combustion } \\
\hline 27 & $\mathrm{CO} 2$, moles & 7.28 & 7.28 & 7.28 \\
\hline 28 & \begin{tabular}{|l|}
$\mathrm{N} 2$, moles \\
\end{tabular} & 276.71 & 336.11 & 549.31 \\
\hline 29 & O2, moles & 63.19 & 78.98 & 135.69 \\
\hline 30 & SO2, moles & 0.007 & 0.007 & 0.007 \\
\hline 31 & Water, moles & 11.850 & 13.053 & 17.368 \\
\hline 32 & $\mathrm{Kg}$ dry gas/ $100 \mathrm{Kg}$ fuel $(\mathrm{CO} 2, \mathrm{~N} 2, \mathrm{O} 2, \mathrm{SO} 2)$ & 10090 & 12259 & 20043 \\
\hline 33 & Kg water $/ 100 \mathrm{Kg}$ fuel & 213 & -235 & 313 \\
\hline 34 & Moisture Content & 0.033 & 0.030 & 0.024 \\
\hline 35 & Mol. Wt. of dry gas, $\mathrm{gm} / \mathrm{mol}$ & 29.063 & 29.024 & 28.952 \\
\hline 36 & Density of dry gas gm/liter at stack temp & 0.646 & 0.721 & 0.782 \\
\hline 37 & $\mathrm{lb} / \mathrm{ft} 3$ & 0.040 & 0.045 & 0.049 \\
\hline 38 & Ib dry gas/lb fuel & 100.90 & 122.59 & 200.43 \\
\hline 39 & Fuel flowrate, & 0.43 & 0.34 & 0.15 \\
\hline 40 & Fuel flowrate, & 3.03 & 2.39 & 1.09 \\
\hline 41 & lb dry gas/min & 5.09 & 4.89 & 3.63 \\
\hline 42 & dry gas acfm & 126.19 & 108.59 & 74.29 \\
\hline 43 & Stack gas flowrate, & 3399 & 2925 & 2001 \\
\hline \multicolumn{5}{|l|}{44} \\
\hline \multicolumn{5}{|l|}{45} \\
\hline \multicolumn{5}{|l|}{46} \\
\hline \multicolumn{5}{|l|}{47} \\
\hline \multicolumn{5}{|l|}{48} \\
\hline 49 & & & & \\
\hline
\end{tabular}


DATA FOR THE BABINGTON UNIT - DIESEL FUEL

\begin{tabular}{|c|c|c|c|c|}
\hline & V & $\bar{w}$ & $\mathbf{x}$ & $\mathbf{Y}$ \\
\hline 50 & Gas Emissions as Measured (dry basis): & & & \\
\hline 51 & CO - startup peak, $\quad$ ppm & 25 & 18 & 94 \\
\hline 52 & CO - steady state, & 6 & 7 & 4 \\
\hline 53 & CO - shutdown peak, & 30 & 16 & 4 \\
\hline 54 & NOx & 37 & 24 & 14 \\
\hline 55 & $\% \mathrm{O} 2$ & 18.2 & 18.7 & 19.6 \\
\hline \multicolumn{5}{|l|}{56} \\
\hline 57 & Particulate Measurements & & & \\
\hline 58 & Total amount collected, gm & 0.0058 & 0.0082 & 0.0042 \\
\hline 59 & Temp. at meter, $\quad \mathrm{F}$ & 71 & 78 & 76 \\
\hline 60 & Dry gas volume sampled, $\quad$ dcf & 62.283 & 108.882 & 63.306 \\
\hline 61 & Dry gas volume sampled, std. cond., dscf & 61.931 & 106.858 & 62.361 \\
\hline 62 & $\begin{array}{l}\text { Concentration of particulates in stack gas, dry basis, } \\
\mathrm{mg} / \mathrm{dscf}\end{array}$ & 0.094 & 0.077 & 0.067 \\
\hline \multicolumn{5}{|c|}{$N_{0}$} \\
\hline 64 & Formaldehyde Measurements & & & \\
\hline 65 & Total mass collected, ug & 5 & 4 & 4 \\
\hline 66 & Volume sampled, (std. liters) & 96.5 & 103 & 98.5 \\
\hline 67 & Concentration in vol. sampled, $\mathrm{mg} / \mathrm{scm}$ & 0.052 & 0.039 & 0.041 \\
\hline 68 & $\mathrm{mg} / \mathrm{scf}$ & 0.001 & 0.001 & 0.001 \\
\hline 69 & Total formaldehyde emitted, $\quad \mathrm{lb} / \mathrm{lb}$ fuel & $3.63008 \mathrm{E}-06$ & $2.96148 \mathrm{E}-06$ & $4.66774 \mathrm{E}-06$ \\
\hline 70 & Concentration of formald. in stack, $\mathrm{ppm}$ & 0.042 & 0.032 & 0.033 \\
\hline 71 & & & & \\
\hline
\end{tabular}




\begin{tabular}{|c|c|c|c|c|}
\hline & $\mathbf{z}$ & AA & $A B$ & $A C$ \\
\hline 1 & \multirow{2}{*}{\multicolumn{4}{|c|}{$\begin{array}{l}\text { TESTING OF PROTOTYPE BURNERS - WORK CONDUCTED FOR U.S. ARMY, NATICK R\&D CT } \\
\text { THIS DATABASE (SETUP ON EXCEL 4.0) PROVIDES THE RAW DATA AND CALCULATIONS } \\
\end{array}$}} \\
\hline 2 & & & & \\
\hline 3 & \multicolumn{4}{|c|}{ NEEDED TO DETERMINE STOVE EMISSIONS WITH DIFFERENT FUEL TYPES } \\
\hline 4 & Prepared by Wai-Lin Litzke and Yusuf Celebi & & & \\
\hline \multicolumn{5}{|c|}{ 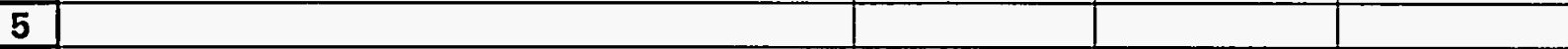 } \\
\hline 6 & Burner Type & Babington & Babington & Babington \\
\hline 7 & Burner Operating Condition & High & Mid & Low \\
\hline 8 & Fuel Type & $\mathrm{JP}-8$ & $\mathrm{JP}-8$ & $\mathrm{JP}-8$ \\
\hline \multicolumn{5}{|l|}{9} \\
\hline 10 & Fuel Composition (\% by wt) & & & \\
\hline 11 & $\% \mathrm{C}$ & 85.7 & 85.7 & 85.7 \\
\hline 12 & $\% \mathrm{H}$ & 14.2 & 14.2 & 14.2 \\
\hline 13 & $\% \mathrm{~S}$ & 0.1 & 0.1 & 0.1 \\
\hline \multicolumn{5}{|l|}{14} \\
\hline \multicolumn{5}{|c|}{15 Operating Conditions } \\
\hline 16 & Stack draft, & 0.058 & 0.052 & 0.045 \\
\hline 17 & Stack Temp. , $\quad F$ & 521 & 424 & 337 \\
\hline 18 & Stack Temp, K $\quad$ (Ts) & 545 & 491 & 442 \\
\hline 19 & $\% 02$ measured, dry basis & 19.1 & 19.6 & 20 \\
\hline 20 & beta term & 10.69 & 10.69 & 10.69 \\
\hline 21 & alpha & 9.31 & 12.95 & 18.45 \\
\hline 22 & $\%$ Excess Air & 931 & 1295 & 1845 \\
\hline 23 & $(1+$ alpha) & 10.31 & 13.95 & 19.45 \\
\hline 24 & kg water $/ \mathrm{kg}$ dry air $=W$ (ie. ambient $=.01$ ) & 0.01 & 0.01 & 0.01 \\
\hline \multicolumn{5}{|c|}{ 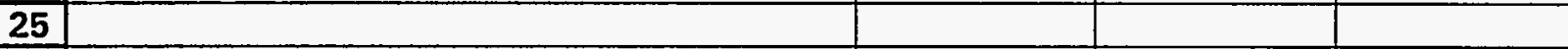 } \\
\hline 26 & Products of Combustion & & & \\
\hline 27 & $\mathrm{CO} 2$, moles & 7.14 & 7.14 & 7.14 \\
\hline 28 & N2, moles & 414.61 & 560.80 & 782.14 \\
\hline 29 & O2, moles & 99.57 & 138.45 & 197.32 \\
\hline 30 & SO2, moles & 0.003 & 0.003 & 0.003 \\
\hline 31 & Water, moles & 15.491 & 18.450 & 22.930 \\
\hline 32 & $\mathrm{Kg}$ dry gas/ $100 \mathrm{Kg}$ fuel $(\mathrm{CO} 2, \mathrm{~N} 2, \mathrm{O} 2, \mathrm{SO} 2)$ & 15110 & 20447 & 28529 \\
\hline 33 & $\mathrm{Kg}$ water $/ 100 \mathrm{Kg}$ fuel & 279 & 332 & 413 \\
\hline 34 & Moisture Content & 0.029 & 0.025 & 0.023 \\
\hline 35 & Mol. Wt. of dry gas, $\mathrm{gm} / \mathrm{mol}$ & 28.983 & 28.946 & 28.916 \\
\hline 36 & Density of dry gas gm/liter at stack temp & 0.649 & 0.719 & 0.797 \\
\hline 37 & $\mathrm{lb} / \mathrm{ft} 3$ & 0.041 & 0.045 & 0.050 \\
\hline 38 & Ib dry gas $/ \mathrm{lb}$ fuel & 151.10 & 204.47 & 285.29 \\
\hline 39 & Fuel flowrate, & 0.35 & 0.22 & 0.14 \\
\hline 40 & Fuel flowrate, & 2.31 & 1.46 & 0.94 \\
\hline 41 & lb dry gas/min & 5.82 & 4.97 & 4.46 \\
\hline 42 & dry gas acfm & 143.78 & 110.65 & 89.58 \\
\hline 43 & Stack gas flowrate, & 3873 & 2981 & 2413 \\
\hline \multicolumn{5}{|l|}{44} \\
\hline \multicolumn{5}{|l|}{45} \\
\hline \multicolumn{5}{|l|}{46} \\
\hline \multicolumn{5}{|l|}{47} \\
\hline \multicolumn{5}{|l|}{48} \\
\hline 49 & & & & \\
\hline
\end{tabular}


DATA FOR THE BABINGTON UNIT - JP-8 FUEL

\begin{tabular}{|c|c|c|c|c|}
\hline & $\mathbf{z}$ & AA & $A B$ & $\overline{A C}$ \\
\hline 50 & Gas Emissions as Measured (dry basis): & & & \\
\hline$\overline{51}$ & CO - startup peak, $\quad$ ppm & 21 & 109 & 43 \\
\hline 52 & CO - steady state, & 8 & 6 & 4 \\
\hline 53 & CO - shutdown peak, $\quad$ ppm & 27 & 18 & 9 \\
\hline 54 & NOx & 34 & 22 & 16 \\
\hline 55 & $\% \mathrm{O} 2$ & 19.1 & 19.6 & 20 \\
\hline \multicolumn{5}{|c|}{56} \\
\hline 57 & Particulate Measurements & & & \\
\hline 58 & Total amount collected, & 0.0043 & 0.0029 & 0.0024 \\
\hline 59 & Temp. at meter, $\quad F$ & 74 & 68 & 72 \\
\hline 60 & Dry gas volume sampled, $\quad$ dcf & 62.65 & 63.267 & 64.039 \\
\hline 61 & Dry gas volume sampled, std. cond., dscf & 61.946 & 63.267 & 63.558 \\
\hline 62 & $\begin{array}{l}\text { Concentration of particulates in stack gas, dry basis, } \\
\mathrm{mg} / \text { dscf }\end{array}$ & 0.069 & 0.046 & 0.038 \\
\hline \multicolumn{5}{|c|}{63} \\
\hline 64 & Formaldehyde Measurements & & & \\
\hline 65 & Total mass collected, ug & 1.2 & 1 & 1.2 \\
\hline 66 & Volume sampled, (std. liters) & 66 & 96.48 & 98.24 \\
\hline 67 & Concentration in vol. sampled, $\mathrm{mg} / \mathrm{scm}$ & 0.018 & 0.010 & 0.012 \\
\hline 68 & $\mathrm{mg} / \mathrm{scf}$ & 0.001 & 0.000 & 0.000 \\
\hline 69 & Total formaldehyde emitted, $\quad \mathrm{lb} / \mathrm{lb}$ fuel & $1.89925 \mathrm{E}-06$ & $1.32192 \mathrm{E}-06$ & $1.96156 \mathrm{E}-06$ \\
\hline 70 & Concentration of formald. in stack, $\mathrm{ppm}$ & 0.015 & 0.008 & 0.010 \\
\hline 71 & & & & \\
\hline
\end{tabular}

